UNIVERSIDADE DE SÃO PAULO

FACULDADE DE MEDICINA DE RIBEIRÃO PRETO

PATRICIA APARECIDA DE ASSIS

ANÁLISE DOS EFEITOS ANTIANGIOGÊNICOS E ANTIPROLIFERATIVOS DA HALOFUGINONA NA

LEUCEMIA PROMIELOCÍTICA AGUDA

Ribeirão Preto - SP

2010 


\title{
ANÁLISE DOS EFEITOS ANTIANGIOGÊNICOS E ANTIPROLIFERATIVOS DA HALOFUGINONA NA LEUCEMIA PROMIELOCÍTICA AGUDA
}

\author{
Dissertação apresentada à Faculdade de \\ Medicina de Ribeirão Preto da Universidade \\ de São Paulo para obtenção do título de mestre \\ em ciências. \\ Área de concentração: Imunologia Básica e \\ Aplicada
}

Orientador: Prof. Dr. Eduardo Magalhães Rego

Ribeirão Preto - SP 
Autorizo a reprodução e divulgação total ou parcial deste trabalho, por qualquer meio convencional ou eletrônico, para fins de estudo e pesquisa, desde que citada a fonte.

\section{Ficha Catalográfica}

Assis, Patricia Aparecida

Análise dos efeitos antiangiogênicos e antiproliferativos da halofuginona na leucemia promielocítica aguda. Ribeirão Preto, 2010.

115 p.: il.; $30 \mathrm{~cm}$.

Dissertação de Mestrado apresentada à Faculdade de Medicina de Ribeirão Preto / USP - Área de concentração: Imunologia Básica e Aplicada

Orientador: Rego, Eduardo M.

1. Leucemia Promielocítica Aguda. 2. Angiogênese.

3. VEGF. 4. Halofuginona. 


\title{
FOLHA DE APROVAÇÃO
}

\author{
Patricia Aparecida de Assis
}

Análise dos efeitos antiangiogênicos e antiproliferativos da halofuginona na Leucemia Promielocítica Aguda

Dissertação apresentada à Faculdade de Medicina de Ribeirão Preto da Universidade de São Paulo para obtenção do título de mestre em ciências.

Área de concentração: Imunologia Básica e Aplicada

Aprovada em:

Banca Examinadora:

Prof(a). Dr(a)

Instituição Assinatura

Prof(a). Dr(a)

Instituição Assinatura

Prof(a). Dr(a)

Instituição Assinatura 
Dedico este trabalho à minha mãe, Nelma, por estar sempre ao meu lado, incentivando e apoiando minhas escolhas. Por trabalhar tanto e frente a tantas dificuldades para garantir meus estudos e permitir que eu seguisse os caminhos que escolhi. Por acreditar e me ensinar que tudo é possível e por sua fé inabalável que me fortalece a cada dia.

E à minha irmã Nayara (Bah), cada vez mais presente em minha vida apesar da distância. Desejo imensamente que você possa realizar seus sonhos. 


\section{AGRADECIMENTOS}

Ao Prof. Dr. Eduardo Magalhães Rego por me receber em seu laboratório, pela oportunidade, pela orientação, por ser sempre agradável e incentivador e pela imensa contribuição para o meu crescimento intelectual.

Ao Prof. Dr. Arnon Nagler, do Chain Sheba Medical Center, em Israel, por ter gentilmente cedido a halofuginona estudada neste trabalho.

À Profa. Dra. Patricia Nicolucci, por sua inestimável contribuição no início deste trabalho conduzindo nossos experimentos de irradiação dos camundongos.

Ao Prof. Dr. Fernando Chahud, por todo suporte na parte técnica e nas análises histopatológicas e de imunohistoquímica.

À Dalva Tereza Catto, por sua agradável presença e postura atenciosa, sem a qual eu não estaria em Ribeirão Preto. Você foi um anjo que por sorte estava no meu caminho.

À secretária Ana Cristine S. Ferreira, pela dedicação e toda atenção com que cuida da pósgraduação e de cada pós-graduando.

À Lorena Lobo de Figueiredo Pontes, pela oportunidade de trabalharmos juntas, pelas discussões sempre enriquecedoras, por confiar no meu trabalho e por sua amizade.

À Dra. Ana Silvia Gouvêa de Lima, pela orientação e inestimável contribuição em todo meu período de mestrado.

À Aglair Bérgamo Garcia e Denise Palma Gallo, pela paciência ao me orientarem no trabalho com cultura de células e nos experimentos de citometria de fluxo e pela contribuição técnica em todo meu trabalho.

À Amélia Góes de Araújo e Márcia Sueli Baggio pela orientação e contribuição técnica nos experimentos de expressão gênica e ensaios imunoenzimáticos.

À Cleide, Andressa, Leandro, Ronaldo e Antônio, por todo auxílio com os animais do biotério, pela paciência, e principalmente pelo excelente café.

Aos colegas de pós-graduação no Laboratório de Hematologia Antônio, Bárbara, Luciana, Alexandre, Mariana, Ana Paula, Guilherme, Priscila, Hamilton e Rafael pela convivência, pelo que pude aprender com cada um, e por direta ou indiretamente contribuírem na execução deste trabalho. 
Aos colegas de trabalho do Laboratório de Hematologia com os quais convivi diariamente e que direta ou indiretamente contribuíram para a execução deste trabalho.

À Elaine Cristina Teixeira, que de forma brilhante, gentil e altruísta me ensinou os primeiros passos na pesquisa. Sem sua contribuição não conseguiria desenvolver esse trabalho. Obrigada acima de tudo por sua amizade.

À Profa. Dra. Maria Célia Bertolini, do Instituto de Química de Araraquara-Unesp, minha orientadora na iniciação científica, pelo exemplo de didática e excelente orientação. Esse trabalho também é fruto do que aprendi em seu laboratório

Ao Prof. Luiz Marcos da Fonseca, da Faculdade de Ciências Farmacêuticas da Unesp, por ser um professor completo preocupando-se formação de seus alunos dentro e fora das salas de aula. Principalmente por sua ajuda em minha vinda para Ribeirão Preto. Tenho orgulho de ter sido sua aluna.

Aos meus velhos amigos de faculdade: Gabriel, Michele, Mônica Jacão, Viviane Yuri, André, Bia, Gisele, Werner e Xicó. Minha vida não teria a mesma graça sem vocês. Todos os dias eu sinto falta de nossa convivência, risadas, brigas, etc. Mas sei que cada um de nós está em busca de seu lugar no mundo. Vocês com certeza são responsáveis por muito que aprendi, obrigada por torcerem sempre e por acreditarem em mim.

À minhas amigas da República PANDORA, Amandinha, Maria, Tina e Thaís, pelos anos de convivência, por cada uma à sua maneira me ensinar algo, por partilharem das minhas melhores lembranças e por ainda serem minhas amigas. Saudades de vocês!!! Uma vez Pandora.... Pandora até morrer!!!!!!!!!!

Aos meus novos amigos e companheiros de pós-graduação: Milena, Everton, Thaís, Elyara,

Maria Cláudia, Mirela, Sandro, Tiago, Zé, Bruno, Helder, Rafael, Gilberto, por dividirem as angústias do dia-a-dia e por estarem ao meu lado nos bons momentos....que não são poucos!!! Torço por todos vocês!!!

À FAPESP (Processo n ${ }^{\circ}$ 2008/ 52634-5) pelo auxílio financeiro, fundamental para a realização deste trabalho. 


$$
\text { Veja }
$$

Não diga que a canção está perdida

Tenha fé em Deus, tenha fé na vida

Tente outra vez

Beba

Pois a água viva ainda está na fonte

Você tem dois pés para cruzar a ponte

Nada acabou, não não não não

Tente

Levante sua mão sedenta e recomece a andar

Não pense que a cabeça agüenta se você parar,

não não não não

Há uma voz que canta,

uma voz que dança,

uma voz que gira

Bailando no ar

Queira

Basta ser sincero e desejar profundo

Você será capaz de sacudir o mundo, vai

Tente outra vez

Tente

E não diga que a vitória está perdida

Se é de batalhas que se vive a vida

Tente outra vez

Tente outra vez (Raul Seixas) 


\section{RESUMO}

Assis, P.A. Análise dos efeitos antiangiogênicos e antiproliferativos da halofuginona na leucemia promielocítica aguda. 2010. 115f. Dissertação (Mestrado) - Faculdade de Medicina de Ribeirão Preto, Universidade de São Paulo, Ribeirão Preto, 2010.

Angiogênese é o termo utilizado para descrever o crescimento de novos vasos sanguíneos a partir dos já existentes. Vários estudos demonstraram a densidade microvascular (DMV) como um fator prognóstico nas leucemias, em particular, leucemia promielocítica aguda (LPA). Este subtipo de leucemia corresponde a cerca de 20 a $25 \%$ das leucemias mielóides agudas nos países latino-americanos e apresenta características clínicas, morfológicas e biológicas peculiares. A halofuginona (HF), originalmente descrita como um agente antifúngico apresenta capacidade de inibir o crescimento tumoral e formação de vasos em modelos animais de tumores sólidos. Estudos realizados por nosso grupo demonstraram que a HF inibiu a secreção do VEGF e a proliferação de linhagens celulares de LPA. Desta forma, o presente trabalho teve por objetivo determinar o potencial antiproliferativo e antiangiogênico da HF em um modelo experimental in vivo da LPA e avaliar os mecanismos subjacentes a sua ação. Primeiramente, a análise do ciclo celular em células NB4 tratadas com HF apresentou significativa diminuição da proliferação celular $(2,093 \pm 0,304$ vs. 41,21 \pm $3,25)$, juntamente com um aumento significativo da apoptose $(12,53 \pm 1,53$ vs. $21,95 \pm 0,79$; $\mathrm{p}=0,0007)$. Por meio da técnica de Real Time Array foi possível identificar dois grupos de genes associados a apoptose celular diferencialmente expressos em células tratadas com HF: TNF, TNFRSF9, TNFTSF10B, CD40, FAS, CASP10, CASP8 e CASP3, sugerindo que a HF induz a via extrínseca de apoptose. A análise in vivo da HF foi realizada em camundongos NOD/SCID previamente irradiados e transplantados com células leucêmicas PML-RAR $\alpha$ murinas. Camundongos tratados com HF, por 21 dias após o transplante não apresentaram remissão molecular, determinada pela amplificação do gene $P M L-R A R A$ por PCR, porém foi observada menor infiltração leucêmica em relação aos camundongos não tratados (Leucócitos: 4,2 $\pm 3,89$ vs. 20,6 $\pm 21,9 ; p<0.0001$ ); Hemoglobina: $12,0 \pm 1,40$ vs. 9,6 \pm 1,67; p $<0.0001$; e Plaquetas: $932,0 \pm 122,5$ vs. $552,0 \pm 83,2$; $<<0.001$ respectivamente) e um menor peso relativo do baço $(0,006$ vs. $0,012, \mathrm{p}=0,0415)$. Ademais, a contagem diferencial e imunofenotipagem da medula óssea evidenciaram menor porcentagem de células mielóides imaturas $(16,88 \pm 6,27$ vs. 44,06 $\pm 27,06)$. A HF também foi capaz de inibir a fosforilação de SMAD2 e consequentemente bloquear a via do TGF- $\beta$ em células NB4. No entanto, animais 
leucêmicos apresentaram menor nível sérico de TGF- $\beta$ em relação aos saudáveis e tratados $(475,58$ vs. $1.378,45 / 1.146,82 \mathrm{pg} / \mathrm{mL} ; \mathrm{p}<0,0001)$, sugerindo que o blasto leucêmico produz esta citocina e a diminuição de células leucêmicas resultou em diminuição dos níveis séricos de TGF- $\beta$. A HF não aumentou a sobrevida dos animais leucêmicos e a elevação das enzimas hepáticas sugeriu que o tratamento foi hepatotóxico. Por fim, com relação à angiogênese, a análise da expressão gênica mostrou que o tratamento com HF inibiu a expressão de $V E G F$ e $E G F$ e o estudo por imunohistoquímica de seções da medula óssea evidenciou menor expressão VEGF (30 vs. 80\%, p=0,0227), porém não houve diminuição da DMV. O conjunto desses resultados mostrou que a angiogênese é um importante alvo terapêutico na LPA, e que apesar da toxicidade, a HF apresenta potencial antileucêmico, tanto por conta de seus efeitos antiproliferativos e próapoptóticos, quanto por sua capacidade de inibir a produção de fatores próangiogênicos.

Palavras-chave: Leucemia Promielocítica Aguda. Angiogênese. VEGF. Halofuginona 


\begin{abstract}
Assis, P.A. Analysis of the antiangiogenic and antiproliferative effects of halofuginone on acute promyelocytic leukemia. 2010. 115f. Dissertation (Masters) - Faculdade de Medicina de Ribeirão Preto, Universidade de São Paulo, Ribeirão Preto, 2010.
\end{abstract}

Angiogenesis is the term used to describe the growth of new blood vessels from the existing ones. Several studies have demonstrated the microvascular density (MVD) as a prognostic factor in leukemia, particularly acute promyelocytic leukemia (APL). This subtype of leukemia corresponds to 20-25\% of acute myeloid leukemia in Latin America and presents clinical, morphological and biological peculiar characteristics. The halofuginone (HF) originally described as an antifungal agent has ability to inhibit tumor growth and vessel formation in animal models of solid tumors. Our group demonstrated that HF inhibits the VEGF secretion and cell proliferation in APL cell lineages. Thus, this study aimed to determine the antiproliferative and antiangiogenic potential of HF in an experimental model of APL in vivo and evaluate the mechanisms underlying its action. First, the cell cycle analysis in NB4 cells treated with HF showed a significant decrease in cell proliferation $(2.093 \pm 0.304$ vs. $41.21 \pm 3.25)$, along with a significant increase in apoptosis $(12.53 \pm 1.53$ vs . $21.95 \pm 0.79, \mathrm{p}=0.0007)$. Through Real Time Array it was possible to identify two groups of apoptosis associated genes differentially expressed in HF treated cells: $T N F$, TNFRSF9, TNFTSF10B, CD40, FAS, CASP10, CASP8 and CASP3, suggesting that HF induces apoptosis by extrinsic pathway. In vivo analysis of HF was performed in irradiated NOD/SCID mice transplanted with murine PML-RAR $\alpha$ leukemic cells. Mice treated with HF for 21 days after transplantation showed no molecular remission as determined by amplification of $P M L-R A R A$ gene by PCR, however minor leukemic infiltration was observed compared to untreated mice (leukocytes: $4.2 \pm 3.89$ vs . $20.6 \pm 21.9, p<0.0001$ ), hemoglobin: $12.0 \pm 1.40$ vs. $9.6 \pm 1.67, \mathrm{p}<0.0001$, and Platelets: $932.0 \pm 122.5$ vs. $552.0 \pm 83.2, \mathrm{p}<0.001$ respectively) and a lower relative weight of spleen (0.006 vs. 0.012, $\mathrm{p}=0.0415)$. Furthermore, the differential count and immunophenotyping of bone marrow showed a lower percentage of immature myeloid cells $(16.88 \pm 6.27$ vs. $44.06 \pm 27.06)$. The HF was also able to inhibit the SMAD2 phosphorylation and consequently block the TGF- $\beta$ pathway in NB4 cells. However, leukemic animals presented lower serum TGF- $\beta$ compared to the healthy and treated (475.58 vs. $1378.45 / 1146.82 \mathrm{pg} / \mathrm{mL}, \mathrm{p}<0.0001)$, suggesting that the leukemic blasts produces this cytokines and the decrease in leukemic cells resulted in decreased serum levels 
of TGF- $\beta$. The HF did not increase the survival of leukemic animals and elevated liver enzymes suggested that the treatment was hepatotoxic. Finally, regarding angiogenesis, gene expression analysis showed that the HF treatment inhibited the expression of $V E G F$ and $E G F$ and the study by immunohistochemistry of sections of bone marrow showed less VEGF expression ( 30 vs. $80 \%, p=0$ 0227), but there was no decrease in the MVD. Taken together, these results showed that angiogenesis is an important therapeutic target in APL, and despite the toxicity, HF has antileukemic potential, for both the antiproliferative and proapoptotic effects, and also for its ability to inhibit the production of proangiogenic factors.

Keywords: Acute Promyelocytic Leukemia. Angiogenesis. VEGF. Halofuginone 


\section{LISTA DE ABREVIATURAS}

7-AAD - 7-amino-actinomicina

APC - Aloficocianinina

ATRA - Ácido all trans retinóico

bFGF - fator de crescimento de fibroblastos (basic Fibroblast Growth Factor)

BrdU - Bromo-deoxiuridina

CTH - Célula tronco hematopoética

DEPC - Dietil-pirocarbonato

DMV - Densidade Microvascular

dNTP - dinucleotídeo trifosfato

EGF - Fator de crescimento epidérmico (Epidermal Growth Factor)

ERK1/2 - Quinase regulada por sinal extracelular 1/2 (do inglês, Extracelular signalregulated kinase1/2)

FAB - Classificação franco-américo-britânica das leucemias agudas

FITC - Fluorocromo fluoresceína-isotiocianato

HDAC - Histonas desacetilases

HF - Halofuginona

HGF - Fator de crescimento de hepatócitos (Hepatocyte Growth Factor)

HIF-1 - Fator induzido por hipóxia 1 (hypoxia-inducible factor-1)

IGF-1 - Fator de Crescimento Insulínico 1 (insulin growth factor-1)

IFN $\gamma$ - Interferon gama

IL-1 - Interleucina-1

IL-4 - Interleucina-4

IL-6 - Interleucina-6

IL-8 - Interleucina-8

IL-13 - Interleucina-13

KGF - Fator de crescimento de queratinócitos (Keratinocyte Gowth Factor)

LMA - Leucemia Mielóide Aguda

LPA - Leucemia Promielocítica Aguda

MAPK - Proteina quinase ativada por mitógeno (Mitogen-activated protein kinase)

MMP-2 - Metaloproteinase-2

MMP-9 - Metaloproteinase-9 
mRNA - RNA mensageiro

NCBI - do Inglês, National Center for Biotechnology Information

NFкB - fator nuclear kappa B (do inglês, Nuclear Factor kappa B)

OMS - Organização Mundial da Saúde

p38-MAPK - do Inglês, $p 38$-Mitogen-activated protein kinase

PAI-1 - Inibidor do ativador do plasminogênio-1 (Plasminogen Activator Inhibitor)

PBS - Salina tamponada (Phosphate Buffered Saline)

PCR - Reação em cadeia de polimerase (Polymerase Chain Reaction)

PDGF - Fator de crescimento derivado de plaquetas (Platelet-Derived Growth Factor)

PE - Fluorocromo ficoeritrina

PIGF - Fator de crescimento derivado de placenta (Placent-derived Growth Factor)

PML - Leucemia Promielocítica (Promyelocytic Leukemia)

RAR $\alpha$ - Receptor alfa do ácido retinóico (Retinoic Acid Receptor Alpha)

SARA - do inglês, Smad-anchor for receptor activation

SBF - Soro bovino fetal

T及RI - Receptor I do TGF $\beta$

T $\beta$ RII - Receptor II do TGF $\beta$

TGF及 - Fator beta de crescimento tumoral (Transforming Growth Factor beta)

TNF $\alpha$ - Fator alfa de necrose tumoral (Tumor Necrosis Factor alpha)

VEGF - Fator de crescimento do endotélio vascular (do Inglês, Vascular Endothelial Growth Factor)

VEGFR-1 - Receptor 1 do VEGF

VEGFR-2 - Receptor 2 do VEGF

VEGFR-3 - Receptor 3 do VEGF 


\section{SUMÁRIO}

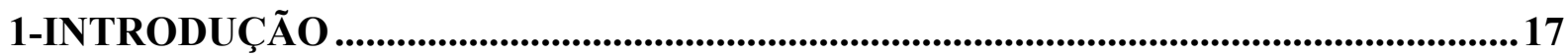

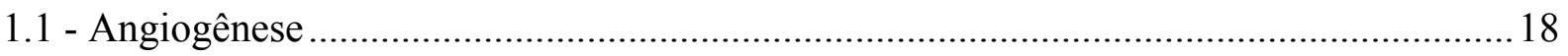

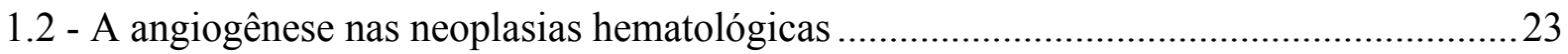

1.3 - Angiogênese e a patogênese das leucemias mielóides agudas............................................25

1.4 - Relação entre angiogênese e leucemia promielocítica aguda ..............................................2

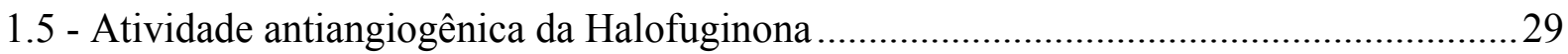

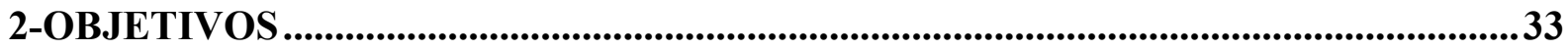

2.1 - Objetivo Principal ………………………………………………………….....

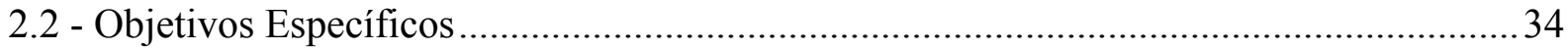

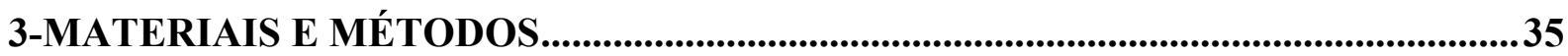

\section{PARTE - I: Análise in vitro dos efeitos da halofuginona na LPA}

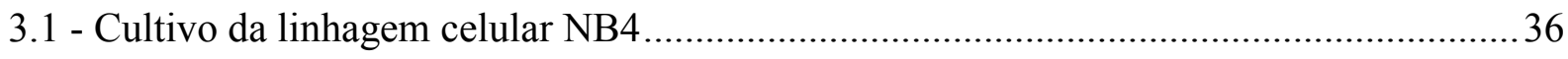

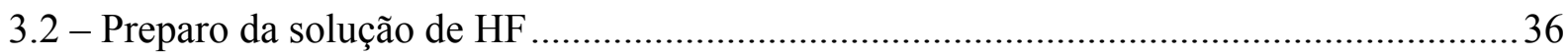

3.3 - Ensaios de proliferação celular e apoptose........................................................................

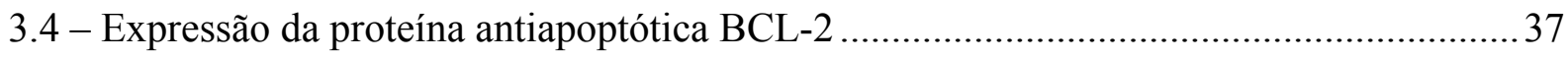

3.5 - Quantificação da SMAD2 fosforilada por meio de ensaio imunoenzimático (ELISA)...38

3.6 - Estudo da modulação da expressão de genes reguladores da apoptose pelo tratamento

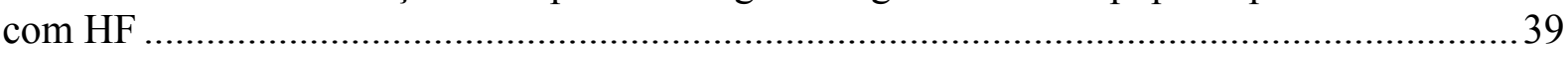

PARTE II - Estudo dos efeitos da halofuginona no modelo in vivo de leucemia promielocítica aguda

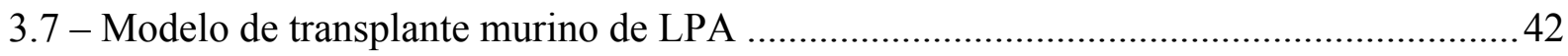

3.7.1 - Padronização do modelo de transplante e do tratamento com halofuginona ..................42

3.7.2 - Transplante de células leucêmicas em camundongos NOD/SCID .................................4 44

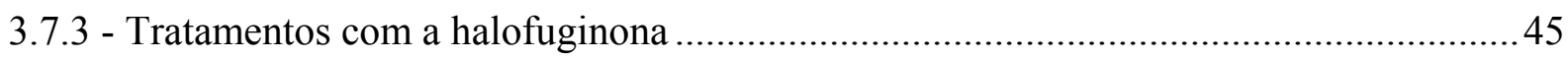

3.8 - Análise dos efeitos da Halofuginona no modelo in vivo da LPA .....................................47

3.8.1 - Avaliação da resposta hematológica e molecular ............................................................4

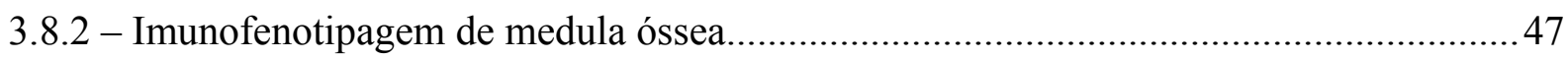

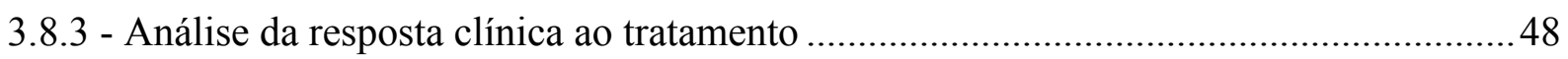

3.8.4 - Análise da toxicidade da halofuginona.................................................................... 
3.9 - Análise da expressão de genes envolvidos com a angiogênese e genes-alvo da via do TGF- $\beta$ por PCR em Tempo Real

3.10 - Quantificação da expressão de TGF- $\beta$ no soro e medula óssea dos camundongos transplantados por meio de ELISA

3.11 - Análise da expressão do VEGF e da densidade microvascular em biópsias de

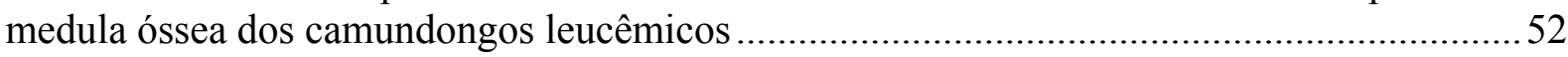

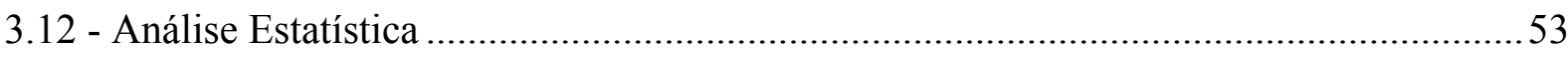

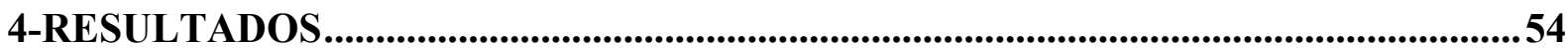

PARTE - I: Análise in vitro dos efeitos da halofuginona na LPA

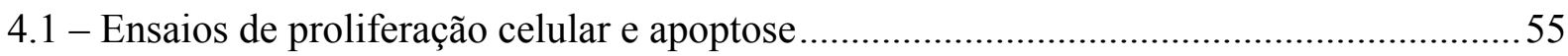

4.1.1 - Estudo do ciclo celular por incorporação de BrdU e marcação com 7-AAD...............55

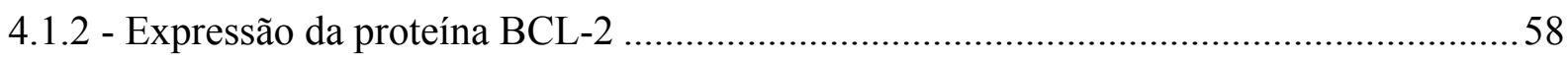

4.2- Quantificação da SMAD2 fosforilada por meio de ensaio imunoenzimático (ELISA) ...59

4.3 - Pesquisa das vias de apoptose alteradas pelo tratamento com HF por meio de PCR array

PARTE II - Estudo dos efeitos da halofuginona no modelo in vivo de leucemia promielocítica aguda

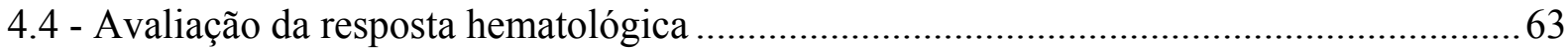

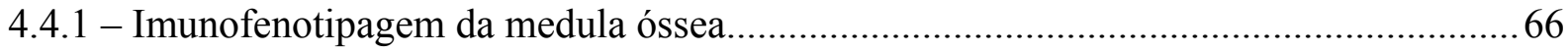

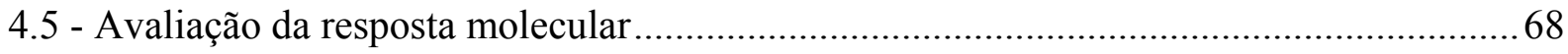

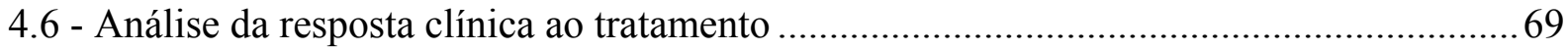

4.6.1 - Avaliação do peso e infiltração do baço dos animais transplantados............................ 69

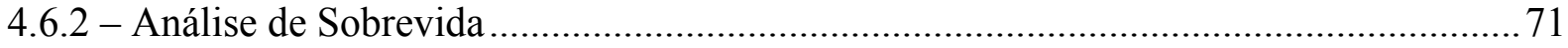

4.6.3 - Análise histomorfológica da toxicidade da halofuginona ........................................... 72

4.7 - Pesquisa de indicadores bioquímicos de toxicidade hepática e renal............................. 74

4.8 - Expressão de genes envolvidos com a angiogênese e genes-alvo da via do TGF- $\beta$ por

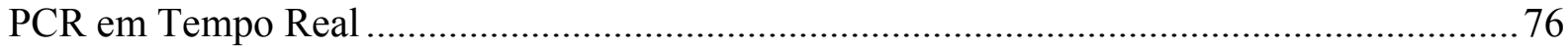

4.9 - Quantificação da expressão de TGF- $\beta$ no soro e medula óssea dos camundongos

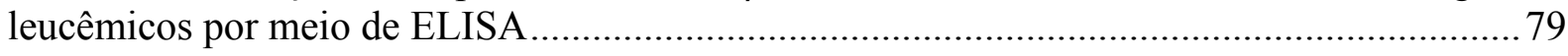

4.10 - Análise da expressão do VEGF e da DMV em biópsias de medula óssea dos

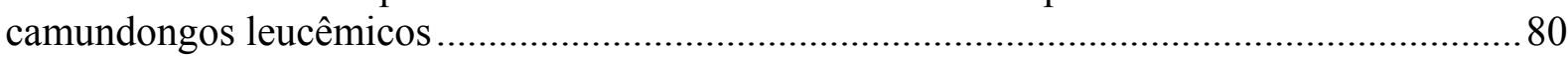

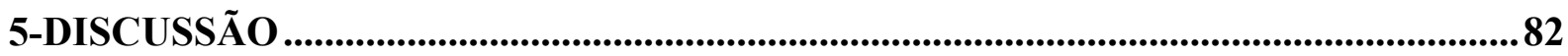

5.1 - A halofuginona exerce efeitos anti-proliferativos e pró-apoptóticos na LPA .................83

5.2 - Halofuginona apresenta potencial antileucêmico em modelo in vivo de LPA ................ 84

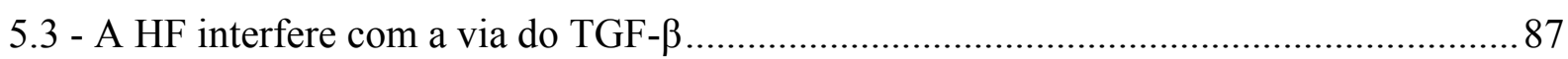


5.4 - A HF interfere com outras vias reguladoras da apoptose.

5.5 - HF reduz os níveis de moléculas pró-angiogênicas, mas não reduz a densidade microvascular.

6-CONCLUSÃO

REFERÊNCIAS BIBLIOGRÁFICAS

ANEXOS

ANEXO A - Parecer do Comitê de Ética em Pesquisa.

ANEXO B - Genes analisados pelo kit $\mathrm{RT}^{2}$ Profiler $^{\mathrm{TM}}$ PCR Array (SA Biosciences, Frederick, MD, USA). A média dos Cts obtidos foram utilizadas para cálculo do fold change $\left(2^{-\Delta \Delta \mathrm{Ct}}\right)$.

ANEXO C - Resumo do trabalho apresentado na forma de pôster na XXXIX Annual Meeting of The Brazilian Biochemistry and Molecular Biology Society 2010 (SBBq 2010), em Foz do Iguaçu, PR, Brasil.

ANEXO D - Resumo do trabalho apresentado na forma de pôster na XXXIVAnnual Meeting of The Brazilian Society for Immunology 2009 (SBI 2009), em Salvador, BA, Brasil. 
1-Introdução 


\section{1 - Angiogênese}

Angiogênese é o processo de formação de novos vasos a partir de vasos pré-existentes. É um processo de múltiplas etapas, incluindo proliferação e migração de células endoteliais, degradação da membrana basal e organização de novos lúmens vasculares (FOLKMAN, 1995). Por ser um processo biológico complexo, a angiogênese é precisamente regulada por diferentes moléculas em cada uma das diferentes etapas (TELLO-MONTOLIU et al., 2006), resumidas da seguinte forma:

(1)-Vasodilatação dos vasos preexistentes e formação de organelas vesículovacuolares nas células endoteliais, sendo o VEGF (Vascular Endothelial Growth Factor) o mediador mais importante no processo;

(2)-Desestabilização dos vãos e degradação da matriz extracelular. Angiopoietina-2 e metaloproteases estão envolvidas nessa estapa;

(3)-Proliferação e migração de células endoteliais, sob a ação de gradientes quimiostáticos, através da membrana basal desintegrada para o espaço perivascular remodelado. Os agentes específicos desses eventos são VEGF e angiopoietinas. Outras moléculas, como angiogeninas, bFGF (basic fibroblast growth factor), EGF (epidermal growth factor), CXC-quimiocinas e IGF-1 (insulin-like growth factor type 1) induzem a proliferação de diferentes tipos celulares;

(4)-Formação de lúmens vasculares e estabilização dos vasos por meio de modificações das células endoteliais que sofreram migração, as quais se convertem em estruturas tubulares com células mesenquimais e células da musculatura lisa adjacente. VEGF e integrinas estão implicados nesse processo. 
Fisiologicamente, a angiogênese é fundamental no crescimento e desenvolvimento somático, na reprodução, nos processos de cicatrização e reparo tecidual. Por outro lado, a neovascularização patológica foi descrita em diferentes doenças não malignas e câncer (CARMELIET 2005). De acordo com diversas hipóteses, o processo de formação de novos vasos é regulado por um delicado equilíbrio entre a produção de fatores ativadores e inibidores (RIBATTI et al., 2007), os quais são produzidos por diferentes tipos celulares, como: células estromais, células endoteliais, células do sistema imune, células tumorais ou ainda pela matriz extracelular (INDRACCOLO et al., 2006). A alteração deste equilíbrio pode ser o ponto chave determinando que deixe de ser um processo fisiológico e torna-se um evento patológico (RIBATTI et al., 2007).

Durante a angiogênese fisiológica, novos vasos são rapidamente formados e estabilizados, enquanto que no processo patológico, como em tumores, a produção alterada de fatores ativadores, dá origem a novos vasos incapazes de se manterem quiescentes. Consequentemente, estas estruturas estão em constante proliferação, fazendo com que a vasculatura tumoral apresente características diferentes do sistema circulatório normal (BERGERS \& BENJAMIN, 2003). Este desequilíbrio, comum em tumores, pode ocorrer em diferentes estágios da progressão da doença, e isto é dependente do tipo do tumor e do microambiente no qual ele se encontra (DOR et al., 2001; KERBEL \& FOLKMAN, 2002).

Os mais conhecidos agentes promotores da angiogênese são: VEGF, o bFGF, a angiogenina e angiopoietinas. Outras citocinas, como IL-1 (interleucina-1), IL-6 (interleucina6), IL-8 (interleucina-8), TNF $\alpha$ (tumor necrosis factor $\alpha$ ), HGF (hepatocyte growth factor), PDGF (platelet-derived growth factor), EGF também foram descritas como reguladoras da angiogênese (LIN et al., 2004; PANTSCHENKO et al., 2003; HATZI et al., 2002; FUHRMANN-BENZAKEIN et al., 2000). Em contrapartida, a trombospondina-1 e as estatinas apresentam potente atividade antiangiogênica. As estatinas são derivadas de 
proteínas de alto peso molecular, mas não apresentam atividade antiangiogênica, como a angiostatina que deriva de um fragmento do plasminogênio e se liga à ATP sintase e à anexina II, como a endostatina, tumastatina e canstatina, que são fragmentos de colágeno e ligam-se à integrinas (BERGERS \& BENJAMIN, 2003).

O VEGF pertence a uma família de glicoproteínas que compreende os seguintes membros: VEGF-A, VEGF-B, VEGF-C, VEGF-D e VEGF-E, e o PDGF (Placent-Derived Growth Factor) (FERRARA et al., 2003). Esta molécula foi descrita pela primeira vez por Senger e colaboradores como um fator específico de hiperpermeabilidade de vasos em tumores (SENGER et al., 1983), e em 1989 Ferrara e Henzel caracterizaram bioquimicamente essa molécula, e identificaram seu potencial mitótico em células endoteliais vasculares (FERRARA \& HENZEL, 1989).

As diferentes isoformas do VEGF são reconhecidas por receptores do tipo tirosina quinase: VEGFR-1, VEGFR-2 e VEGFR-3 (chamados também de: FLT1. FLK1 e FLT4 respectivamente) (NEUFELD et al., 1999). VEGFR-1 e VEGFR-2 são expressos principalmente em células endoteliais, sendo que o VEGFR-1 é também expresso por células tronco hematopoiéticas, enquanto o VEGFR-2 está presente em células endoteliais precursoras, megacariócitos e células progenitoras da retina (YANG \& CEPKO, 1996; MATTHEWS et al., 1991). Determinados tipos de células tumorais também são capazes de expressar estes dois receptores, como por exemplo, células de melanoma (COHEN et al., 1995).

O receptor VEGFR-2 liga VEGF-A e VEGF-C (e VEGFD em algumas espécies), sendo o receptor primário na ativação da angiogênese tanto em condições fisiológica quanto patológicas. VEGFR-1 liga VEGF-A, VEGF-B e PIGF, enquanto que VEGFR-3 liga VEGFC e VEGF-D (SHIBUYA et al., 1990). O receptor VEGFR-1 apresenta grande afinidade pelo ligante VEGF-A, mas a sua ativação resulta em atividade mitogênica fraca ou ausente. Já o 
VEGFR-2, que tem menor afinidade por este fator, uma vez ativado induz a proliferação, migração, diferenciação e sobrevida de células endoteliais (SHALABY et al., 1995).

Entre as isoformas do VEGF, o VEGF-A é a proteína com maior atividade próangiogênica. Esse fator é capaz de induzir proliferação celular, divisão e formação do tubo em células endoteliais (GUPTA \& ZHANG, 2005). Nessas células, VEGF-A também foi capaz de induzir a expressão de proteínas antiapoptóticas, atuando como um fator de sobrevivência (GERBER et al., 1998). A expressão de VEGF-A, pode ser induzida por diferentes agentes, como a baixa tensão de oxigênio pelo HIF-1 (Hypoxia-Inducible Factor 1) (SEMENZA, 2000), ou pelas citocinas bFGF, PDGF, HGF, EGF, TNF $\alpha$, TGF $\beta$, IL-1, IL-6, KGF (Keratinocyte Growth Factor) e IGF-1. Outras citocinas como IL-10 e IL-13 exercem função moduladora antiangiogênica inibindo a secreção de VEGF (NEUFELD et al., 1999). In vivo, a expressão de VEGF-A foi associada com etapas fundamentais da angiogênese e vasculogênese. Em camundongos, a deleção do gene que codifica esta proteína foi letal ao embrião, resultando em defeitos cardiovasculares (CARMELIET et al., 1996). Em humanos, VEGF-A é expressa em praticamente todos os tumores sólidos estudados até o momento, assim como em doenças malignas hematológicas (FERRARA et al., 2003). De fato, diversos estudos demonstraram em diferentes tipos de câncer, uma correlação entre os níveis de expressão de VEGF-A, a progressão da doença e resposta ao tratamento (FERRARA, 2002; LARCHER et al., 1998).

Com relação às outras isoformas, VEGF-B liga-se exclusivamente ao receptor VEGFR-1 e induz um fraco estímulo mitogênico em células endoteliais, sugerindo que VEGF-B não é um fator muito relevante para a angiogênese (NASH et al., 2006). Maiores níveis de sua expressão são encontrados em músculo esquelético, miocárdio e tecido adiposo, o que indica que sua função pode estar associada a células com elevada taxa metabólica (SALVEN et al., 1998; ENHOLM et al., 1997). VEGF-C e VEGF-D ligam-se aos receptores 
VEGFR-2 e 3, e estão principalmente envolvidos na proliferação, migração e sobrevivência de células endoteliais em vasos linfáticos (AKAHANE et al., 2006; KARKKAINEN et al., 2004).

Outro importante fator envolvido na ativação da angiogênese é o TGF- $\beta$ (transforming grown factor- $\beta$ ). Essa molécula pertence a uma extensa família de citocinas da qual cerca de 30 membros são encontrados em mamíferos, incluindo três isoformas de TGF- $\beta$, ativinas e BMPs (bone morphogenetic proteins). Esse grupo de citocinas desempenha importante função na regulação do equilíbrio entre proliferação, apoptose e diferenciação celular, sendo o principal regulador da quiescência em células tronco hematopoéticas $(\mathrm{CTH})$ (SCHMIERER \& HILL, 2007; SHI \& MASSAGUE, 2003; HELDIN et al., 1997). Entretanto, estudos recentes em camundongos knock-out para componentes desta via de sinalização demonstraram que o TGF- $\beta$ é também crítico no processo de angiogênese (GOUMANS et al., 2009). A deleção do gene TGFBI em camundongos resultou em 50\% de letalidade embrionária devido a vasculogênese defectiva do saco vitelíneo (GOUMANS et al., 2009; DICKSON et al., 1995). A importância do TGF- $\beta$ na angiogênese está associada com seus efeitos sobre as células endoteliais, particularmente aqueles envolvendo o estabelecimento e interação dessas células com a membrana basal (HOLDERFIELD \& HUGHES, 2008).

A ativação desta via se faz pela ligação da citocina a um complexo de receptores transmembrana serina/treonina quinases do tipo I e II. São conhecidos cinco receptores do tipo II e sete receptores do tipo I, também chamados de ALKs (activin receptor-like kinases). Após a ligação ao TGF $\beta$, esses receptores formam um complexo heterodimérico no qual o receptor tipo II fosforila o domínio quinase do receptor tipo I, ativando-o. O receptor tipo I ativado fosforila as proteínas SMADs, como SMAD1, SMAD2, SMAD3, SMAD5 e SMAD8, levando a formação do complexo heterodimérico com a SMAD4, que migra para o núcleo. Após a translocação, este complexo se liga na região promotora de determinados genes alvo, 
regulando a sua transcrição (GOUMANS et al., 2009). Em diferentes tipos celulares, o mecanismo comum de ativação se dá por meio dos receptores tipo II como TßRII e ALK5, que induzem a fosforilação das SMADs 2 e 3. Em células endoteliais, além da ativação via ALK5, ocorre também a ativação via ALK1, que por sua vez é responsável pela fosforilação das SMADs 1, 5 e 8. Ainda, o controle desta sinalização é realizado pelas SMADs 6 e 7, que formam complexos estáveis com o receptor T $\beta R I$ impedindo a fosforilação das SMADs (SCHMIERER \& HILL, 2007; SHI \& MASSAGUE, 2003; HELDIN et al., 1997).

Em células endoteliais, a ativação da via do TGF- $\beta$ mediada por ALK1 é responsável por estimular a migração, proliferação e formação do tubo (GOUMANS et al., 2003). Outra relação entre TGF- $\beta$ e angiogênese foi proposta por Sánchez-Elsner e colaboradores, estes autores demonstraram que as vias de sinalização da hipóxia e do TGF- $\beta$ atuam sinergicamente na regulação da expressão do VEGF ao nível transcripcional. O promotor do gene que codifica para o VEGF contém regiões de ligação para HIF-1 bem como para a SMAD3, proteína mediadora da via de sinalização do TGF- $\beta$ (SANCHEZ-ELSNER et al., 2001).

\section{2 - A angiogênese nas neoplasias hematológicas}

A relação entre neovascularização e câncer foi descrita pela primeira vez por Folkman e colaboradores em 1971 (FOLKMAN et al., 1971) e, desde então, vem sendo estudada como um dos mecanismos de progressão tumoral. A detecção de neoformação vascular foi correlacionada ao potencial metastático, recorrência e progressão de diferentes tumores sólidos e tem sido reconhecido como fator prognóstico independente de sobrevida em neoplasias de pulmão, mama, esôfago e próstata (TANIGAWA et al., 1997; WEIDNER et al., 1993; MACCHIARINI et al., 1992;WEIDNER et al., 1991). 
A íntima relação entre angiogênese e progressão tumoral pode ser explicada pela hipótese de que há um momento específico nos estágios iniciais da tumorigênese, chamado switch angiogênico (HANAHAN \& FOLKMAN, 1996), no qual a angiogênese é o evento responsável por permitir a expansão de células neoplásicas. Um dos prováveis mecanismos para este switch é a hipóxia. Devido à alta proliferação das células tumorais há a formação de áreas com baixa tensão de oxigênio dentro da própria massa tumoral. Esta condição induz as células localizadas nessas áreas a expressarem maiores quantidades de VEGF, com subseqüente ativação da angiogênese e favorecimento da progressão tumoral (PLATE et al., 1993). Em adição a esses mecanismos, outros tipos celulares são capazes de produzir fatores pró-angiogênicos, como células endoteliais, macrófagos, mastócitos e linfócitos (CAVALLARO \& CHRISTOFORI, 2000).

Apesar da angiogênese já ter sido bem caracterizada em tumores sólidos, as evidências de seu papel em neoplasias hematológicas foram descritas apenas recentemente. Dentre as neoplasias hematopoiéticas, o papel da angiogênese foi mais bem caracterizado no mieloma múltiplo e nos linfomas não-Hodgkin. Em estudo dirigido por Vacca e colaboradores, pacientes com mieloma múltiplo apresentaram maior densidade microvascular (DMV) comparados com pacientes de gamopatia monoclonal, além de maior índice proliferativo dos plasmócitos (VACCA et al., 1994).

Do ponto de vista clínico, no mieloma múltiplo, há evidências de correlação entre DMV na medula óssea foi associada à maior, proliferação das células plasmocitárias, secreção de metaloproteinases e atividade da doença (BHATTI et al., 2006; VACCA et al., 1999; VACCA et al., 1994). Porém, de maneira geral, a DMV apresenta-se aumentada em pacientes com diferentes neoplasias hematológicas, especialmente em estágios avançados da doença (NEGAARD et al., 2009). 
A maior atividade angiogênica foi importante em diferentes tipos de leucemia. A secreção de altos níveis de VEGF, associada com a alta expressão de VEGFR-1 e VEGFR-2 por células leucêmicas foram correlacionadas com o pior prognóstico e menor sobrevida em pacientes com leucemia linfóide aguda (LLA), leucemia mielóide crônica (LMC) e linfoma não-Hodgkin (WANG et al., 2004; WELLMANN et al., 2004; VERSTOVSEK et al., 2002). A elevada DMV e maior expressão de VEGF foram associadas a um pior prognóstico em vários subtipos de linfomas não-Hodgkin de células B e T (GANJOO, 2007; GRATZINGER et al., 2007; JORGENSEN et al., 2007; MAZUR et al., 2004). Corroborando essas observações, o aumento da vascularização, também foi observado na medula óssea de pacientes com desordens pré-leucêmicas, tais como síndrome mielodisplásica (SMD) (AYALA et al., 2009).

Ademais, não apenas a DMV mostrou-se aumentada nestes casos, mas também a expressão das metaloproteinases-2 (MMP-2) e MMP-9, ambas envolvidas na degradação da membrana basal endotelial. Negaard e colaboradores observaram em 93 pacientes, com diferentes neoplasias hematológicas, elevados níveis séricos dos fatores de crescimento VEGF e FGF2 e das citocinas IL-6 e IL-8 (NEGAARD et al., 2009).

\section{3 - Angiogênese e a patogênese das leucemias mielóides agudas}

Diversos estudos demonstraram aumento da angiogênese em Leucemias Mielóides Agudas (LMAs), incluindo o aumento da microdensidade vascular em pacientes não tratados (HATFIELD et al., 2005; HUSSONG et al., 2000; PADRO et al., 2000), bem como a importância do monitoramento de mediadores angiogênicos para acompanhamento de pacientes no curso da terapia (SCHLIEMANN et al., 2006; LOGES et al., 2005; LAI et al., 2000; AGUAYO et al., 1999). Em pacientes com LMA, Kuzu e colaboradores (KUZU et al., 
2004) identificaram no momento do diagnóstico, uma DMV muito aumentada, comparada com os controles ou com o período pós-tratamento.

Nas leucemias, o microambiente pode contribuir para a angiogênese tanto quanto os blastos leucêmicos, por meio da secreção de diferentes fatores de crescimento e mediadores angiogênicos (LITWIN et al., 2002). No microambiente da medula óssea, o desequilíbrio na produção de fatores pró-angiogênicos ativa o recrutamento e proliferação de células endoteliais, passo essencial para o início da vasculogênese (WATARAI et al., 2002). Hatfield e colaboradores demonstraram que células primárias de LMA promovem o crescimento e proliferação de células endoteliais. No mesmo trabalho, o sobrenadante destas culturas apresentou as mesmas propriedades, sugerindo que essas células são capazes de secretar esses fatores e consequentemente favorecer os mecanismos de neovascularização (HATFIELD et al., 2008).

Células estromais da medula óssea como fibroblastos, adipócitos, células endoteliais e osteoblastos são a maior fonte de fatores de crescimento e citocinas. Em virtude de nas LMAs a composição celular da medula óssea apresentar-se alterada, essa modificação do microambiente leva à diminuição do número de fibroblastos e adipócitos. Entretanto, ainda não se sabe se essas alterações no microambiente resultam em leucemia ou se este é um evento secundário (MAYANI, 1996). Diferentes estudos em síndrome mielodisplásca (SMD) apontam o aumento da densidade microvascular nessa doença. Porém, resultados conflitantes são observados sobre o aumento ou não da DMV durante a transformação para leucemia (WIMAZAL et al., 2007; LUNDBERG et al., 2006; CAMPIONI et al., 2004; KORKOLOPOULOU et al., 2001). Em estudo recente, a DMV e expressão de VEGFR-2, Tie2, bFGF e angiopoietinas eram menores em pacientes com leucemia pós-SMD em relação aos paciente com LMA de novo, sugerindo que na fase tardia da leucemia há uma certa independência da angiogênese (KEITH et al., 2007). 
Ademais, Zhang e colaboradores demonstraram que o tratamento de células de LMA e endoteliais com um anticorpo contra o receptor 2 do VEGF (VEGFR-2/KDR) inibiu a produção de fatores mitogênicos pelas células endoteliais e reduziu a proliferação das células leucêmicas (ZHANG et al., 2004). Outro estudo in vivo demonstrou que camundongos SCID transplantados com células de linhagem leucêmica, apresentaram maior expressão de VEGF e VEGFR-2, e este aumento foi gradual durante o curso da doença (CHEN et al., 2009).

\section{4 - Relação entre angiogênese e leucemia promielocítica aguda}

A Leucemia Promielocítica Aguda (LPA) é um subtipo de Leucemia Mielóide Aguda (LMA) denominada segundo a classificação Franco-Américo-Britânica (FAB) como os subtipos M3 e M3 variante (BENNETT et al., 1980). Na classificação da Organização Mundial da Saúde (OMS), a LPA foi designada como "LMA associada à translocação entre os cromossomos 15 e $17-\mathrm{t}(15 ; 17)(\mathrm{q} 22 ; \mathrm{q} 12) "($ VARDIMAN, 2010).

Todos os casos de LPA estão associados com translocações recíprocas e balanceadas envolvendo o lócus do receptor $\alpha$ do ácido retinóico (RAR $\alpha$ ), localizado no cromossomo 17. Aproximadamente $95 \%$ dos pacientes de LPA apresentam o gene $R A R A$ fusionado ao gene PML (Promyelocytic Leukemia) localizado no cromossomo 15 (GRIMWADE et al., 2000). A translocação t $(15,17)$ resulta na expressão das proteínas de fusão PML-RAR $\alpha$ e RAR $\alpha-P M L$, esta última com função ainda não definida. Por outro lado, a proteína de fusão PML-RAR $\alpha$ por deter a maior parte dos domínios funcionais das proteínas nativas RAR $\alpha$ e PML possui ação dominante negativa nas vias dos retinóides e do PML (MELNICK \& LICHT, 1999; PEREZ et al., 1993). Mais recentemente, também foi demonstrado que PML-RAR $\alpha$ reconhece e liga-se a uma variedade de regiões no DNA muito maior em relação à RAR $\alpha$, sugerindo que há ganho de função pela proteína de fusão (VITOUX; NASR; DE THÉ, 2007). 
Os receptores do ácido retinóico ligam derivados da vitamina $\mathrm{A}$, como o ácido all trans retinóico (ATRA) e estão envolvidos na transcrição de genes importantes para a diferenciação mielóide, como os genes da elastase e da mieloperoxidase (MUINDI et al., 2001). Na LPA, a proteína de fusão PML-RARa é menos sensível aos níveis fisiológicos de ácido retinóico, levando a interrupção destas vias de ativação e consequente interrupção da maturação mielóide no estágio promielocítico.

Os primeiros estudos sobre a angiogênese em pacientes com LPA identificaram a secreção de VEGF pelos blastos leucêmicos (LEUNG et al., 1989). Na análise de expressão gênica, foram encontrados níveis elevados de genes relacionados com fatores de crescimento como HGF, FGF e VEGF em amostras de medula óssea de 10 pacientes com LPA em relação aos demais subtipos de LMAs. Em contrapartida, a expressão gênica do TGF- $\beta$ (um regulador do VEGF) demonstrou-se reduzida em relação às outras categorias (GUTIERREZ et al., 2005).

Kini e colaboradores analisaram a medula óssea de 12 pacientes com LPA demonstrou aumento da DMV e da expressão do VEGF. Após o tratamento com ATRA, houve redução da DMV e da expressão de VEGF nas amostras dos mesmos pacientes (KINI et al., 2001) Estes dados corroboraram com ensaios in vitro, nos quais células da linhagem de LPA, NB4, apresentavam níveis elevados de VEGF e eram capazes de estimular a migração endotelial. Além disto, o tratamento destas células com o anticorpo neutralizante anti-VEGF inibiu completamente a migração endotelial (KINI et al., 2001). Esses achados reforçam a participação do VEGF como regulador da proliferação das células mielóides leucêmicas e sugerem que o aumento da angiogênese na LPA pode dar suporte à proliferação dos promielócitos anormais. 


\section{5 - Atividade antiangiogênica da Halofuginona}

A molécula halofuginona ( $d$ l-trans-7-bromo-6-cloro-3-[3-hidroxi-2-piperidil) acetonil]-4(3H)-hidrobrometo de quinazolinona) foi inicialmente isolada da planta Dichroa febrifuga e usada originalmente como antifúngico na produção comercial de aves (VILLACORTA et al., 1991). Posteriormente, demonstrou-se que a halofuginona (HF) foi capaz de inibir a síntese de colágeno tipo I (MCGAHA et al., 2002) e de reduzir a fibrose em diversos modelos experimentais in vitro e in vivo (FLANDERS, 2004; XAVIER et al., 2004; MCGAHA et al., 2002; PINES \& NAGLER, 1998;). Ademais, através de suas ações antiangiogênicas, a HF foi capaz de inibir o crescimento tumoral em modelos animais de feocromocitoma (GROSS et al., 2003), tumor cerebral (ABRAMOVITCH et al., 2004) e carcinoma hepatocelular (TARAS et al., 2006).

O interesse na ação inibitória da HF sobre a síntese de colágeno tipo I motivou diversos estudos em doenças, nas quais há excessiva deposição de colágeno, como fibrose pulmonar (NAGLER et al., 1996), cirrose hepática (PINES et al., 1997), fibrose renal (BENCHETRIT et al., 2007), escleroderma e cGVHD (chronic graft-versus-host-disease) (PINES et al., 2003). Em um modelo de fibrose hepática induzida por tioacetamina, o tratamento com halofuginona foi capaz de alterar a expressão de diferentes genes envolvidos nesta patologia. Nos estágios iniciais da doença, a halofuginona foi responsável por afetar a expressão de genes envolvidos no metabolismo lipídico, protéico, alcoólico e do fosfato, além de moléculas de adesão. Por outro lado, no momento mais tardio da progressão da doença, os genes afetados relacionam-se basicamente com ciclo celular (desenvolvimento celular, diferenciação, proliferação e apoptose) (GNAINSKY et al., 2007).

A ação inibitória da HF sobre a expressão gênica do gene do colágeno tipo I também já foi bem descrita (PINES et al., 2003; PINES et al., 2001; PINES et al., 1997), além disso, 
seus efeitos foram observados sobre outros genes relacionados com a biossíntese e degradação de colágeno e que também são regulados por TGF- $\beta$. Estes genes correspondem a proteínas como: PCPE-1 (procollagen C-proteinase enhancer protein), a qual está envolvida na deposicão de fibras de colágeno (SHALITIN et al., 2003); lisil oxidase, responsável por catalisar e promover a polimerização da fibra; TIMP-2, cujo efeito é degradar o colágeno via metaloproteinases (SPIRA et al., 2002; BRUCK et al., 2001;).

Os efeitos da halofuginona sobre a expressão gênica não é o único mecanismo de interesse, mas também sua atividade inibitória sobre a fosforilação da proteína SMAD3 (MCGAHA et al., 2002). Recentemente, Roffe e colaboradores evidenciaram, em modelo de distrofia muscular, que a halofuginona induziu a fosforilação das proteínas Akt e MAPK/ERK e por meio deste mecanismo interferiu na via do TGF- $\beta$ mediada por SMAD3 (ROFFE et al., 2010). Akt quando fosforilada liga-se à SMAD3 e impede sua fosforilação (REMY et al., 2004), enquanto que MAPK/ERK uma vez ativada fosforila SMAD3 no domínio N-terminal de ligação ao DNA, interferindo com sua atividade como fator de transcrição (KRETZSCHMAR et al., 1999). Xavier e colaboradores demonstraram que a HF reduziu a fibrose induzida por radiação em camundongos através do aumento da expressão gênica de SMAD7, inibidor da sinalização da via do TGF $\beta$, e expressão protéica das SMADs 2 e 3 (XAVIER et al., 2004).

Além de atuar sobre a sinalização do TGF- $\beta$, a HF também mostrou atividade inibitória sobre a expressão gênica de $M M P 2$ em células humanas e murinas, devido à supressão do promotor dessa metaloproteinase em modelo de carcinoma de bexiga (ELKIN et al., 1999), ainda, inibiu a atividade enzimática da MMP-2 em modelo de carcinoma hepatocelular, reduzindo significantemente o potencial metastático destes tumores (TARAS et al., 2006). 
Estudos dos efeitos antiproliferativos e antiangiogêncos da HF foram realizados em modelos animais de gliomas e feocromocitomas. Em ambos os casos, o tratamento com HF por via oral ou intraperitoneal, diminuiu significativamente o crescimento e a vascularização destes tumores (GROSS et al., 2003; ABRAMOVITCH et al., 1999;). Um dos mecanismos pelo qual a HF inibe a proliferação celular foi demonstrado por ensaios in vitro utilizando células de miométrio e mioma. Culturas dessas células tratadas com HF apresentaram diminuição na síntese de DNA, de maneira dose-dependente, seguida por apoptose (GRUDZIEN et al., 2010). O aumento de apoptose observado neste trabalho e por Gavish e colaboradores (GAVISH et al., 2002) contrariam outro recente estudo, no qual a HF inibiu a apoptose em células T normais ativadas (LEIBA et al., 2006). Estes resultados em conjunto, sugerem que a indução da apoptose pela HF depende do tipo celular.

Ademais, Elkin e colaboradores demonstraram que a HF inibiu eventos críticos na progressão da angiogênese tais como a proliferação de células endoteliais, a invasão da membrana basal, a formação dos tubos capilares e a deposição da matriz celular por novos vasos (ELKIN et al., 2000). Em modelo murino de tumor cerebral, animais tratados com HF apresentaram menor crescimento da massa tumoral associado à menor vascularização (ABRAMOVITCH et al., 2004).

Poucos estudos clínicos foram realizados com HF, sendo principalmente utilizada na aplicação tópica em voluntários normais, não resultando em absorção sistêmica ou irritação da pele. A administração oral foi em geral bem tolerada, com alguns efeitos adversos gastrointestinais nas doses mais elevadas (PINES et al., 2003).

Estudos sobre a ação da HF em células hematopoéticas são mais recentes e sugerem que esta substância tem a capacidade de inibir de maneira dose-dependente a atividade de NFkB bem como a fosforilação da p38-MAPK em células T ativadas (LEIBA et al., 2006). Além disso, a HF foi capaz de inibir a secreção das citocinas TNF $\alpha$, Interferon gama (IFN $\gamma$ ), 
IL-4, IL-13 e TGF $\beta$, sugerindo uma atividade inibitória das funções inflamatórias das células T (BATRA et al., 2004).

O primeiro estudo realizado sobre a HF em linhagens celulares ou células primárias de neoplasias hematológicas foi realizado em nosso laboratório. (FIGUEIREDO-PONTES, Tese de Doutorado). Em ensaios realizados com células de linhagem de LPA, NB4 e NB4-R2, houve inibição do crescimento celular e indução de apoptose de maneira dose-dependente. O estudo do ciclo celular, além de comprovar os efeitos antiproliferativos, mostrou que a droga bloqueia a progressão do ciclo celular na fase G1/S (FIGUEIREDO-PONTES, Tese de Doutorado).

Diante das evidências sobre as atividades antiproliferativas, pró-apoptóticas e antiangiogênicas da HF tanto em modelos de tumor sólido como em linhagens celulares de leucemia, o presente trabalho pretendeu verificar o potencial antileucêmico da HF em um modelo experimental in vivo de LPA. O estudo in vivo dos efeitos da HF em neoplasias hematológicas é inédito e reforça a hipótese que as vias de regulação da angiogênese constituem potenciais alvos terapêuticos no tratamento destas doenças. 
2-Objetivos 


\section{1 - Objetivo Principal}

Avaliar os efeitos da halofuginona em modelos in vitro e in vivo de leucemia promielocítica aguda (LPA)

\section{2 - Objetivos Específicos}

1 - Estudar os efeitos do tratamento com HF na proliferação celular e apoptose em células de linhagem de LPA;

2 - Analisar os efeitos do tratamento com halofuginona em um modelo murino de LPA;

3 - Avaliar os efeitos da halofuginona sobre a angiogênese na medula óssea no modelo murino de LPA. 
3-Materiais e Métodos 


\section{PARTE - I: Análise in vitro dos efeitos da halofuginona na LPA}

\section{1 - Cultivo da linhagem celular NB4}

Células da linhagem leucêmica NB4 (LANOTTE et al., 1991) foram cultivadas em meio RPMI 1640 acrescido de $10 \%$ de SBF e mantidas a $37^{\circ} \mathrm{C}$ e $5 \%$ de $\mathrm{CO}_{2}$. As células foram mantidas em concentrações de 0,5 a $1 \times 10^{6}$ células $/ \mathrm{ml}$ e testadas com mais de $95 \%$ de viabilidade.

\section{2 - Preparo da solução de HF}

Para o preparo de uma solução primária de HF na concentração de $1 \mathrm{mg} / \mathrm{mL}$, o fármaco foi diluído em solução de ácido láctico $(\mathrm{pH} 4,0-4,5)$ e incubado em banho-maria a $37^{\circ} \mathrm{C}$ por 5 minutos para facilitar a dissolução. Esta solução foi esterilizada por meio de filtro $0,22 \mu \mathrm{m}$ e mantida a $4^{\circ} \mathrm{C}$ por até 30 dias. No momento do uso, a solução resultante foi diluída nas concentrações desejadas em meio RPMI 1640 estéril, para utilização em cultura celular, ou em solução salina $(0,9 \% \mathrm{NaCl})$ estéril, para o tratamento dos camundongos. A HF é extremamente fotossensível, sendo assim, todas as etapas de manipulação foram realizadas ao abrigo da luz.

\section{3 - Ensaios de proliferação celular e apoptose}

Células NB4 foram tratadas com HF e em seguida, submetidas à análise do ciclo celular por citometria de fluxo utilizando o BrdU Flow kit (BD Biosciences, San Jose, CA, EUA). Neste método, a bromodeoxiuridina (BrdU), análoga à timidina, é incorporada por 
células que se encontram na fase de síntese de DNA do ciclo celular. A BrdU incorporada é identificada pela ligação ao anticorpo anti-BrdU conjugado com o fluorocromo aloficocianinina (APC). Concomitantemente, as células são marcadas com o corante de DNA total, 7-amino-actinomicina (7-AAD), permitindo a identificação das células que estão ativamente sintetizando DNA (BrdU positivas) de acordo com a fase do ciclo celular (G0/G1, S ou G2/M) definida pela intensidade de marcação com 7-AAD, bem como das células em apoptose (identificadas no pico sub-G0/G1).

O volume de $3 \mathrm{~mL}$ da suspensão celular na concentração de $5 \times 10^{5}$ células $/ \mathrm{mL}$ foi distribuído em placas de 12 poços, e em seguida, procedeu-se o tratamento com adição direta ao meio de cultura de 50, 100 ou $200 \mathrm{ng} / \mathrm{mL}$ de HF. A incubação foi realizada por 12, 24 e 48 horas e, ao final de cada período, as células foram incubadas com $10 \mu \mathrm{M}$ de BrdU durante 30 minutos. Após, as células foram permeabilizadas e fixadas, segundo recomendação e reagentes do próprio kit, tratadas com DNAse para exposição do BrdU incorporado e, finalmente, marcadas com o anticorpo anti-BrdU-APC. A análise do BrdU incorporado foi realizada em citômetro de fluxo FACScalibur. Células não tratadas foram utilizadas como controle negativo e a porcentagem de células em cada fase do ciclo celular foi determinada utilizando o software CellQuest (Becton Dickinson).

\section{4 - Expressão da proteína antiapoptótica BCL-2}

As células NB4 tratadas com as mesmas doses de HF descritas acima também foram permeabilizadas e incubadas com o anticorpo anti-BCL-2-FITC. Assim, este experimento permitiu a análise concomitante da expressão da proteína antiapoptótica BCL-2 e da fase do ciclo celular das células da LPA após tratamento com HF. 


\section{5 - Quantificação da SMAD2 fosforilada por meio de ensaio imunoenzimático (ELISA)}

Para avaliar os efeitos do tratamento com HF sobre a via do TGF- $\beta$, utilizamos a análise dos níveis da proteína SMAD2 em sua forma fosforilada por meio de ensaio imunoenzimático (ELISA). Garrafas contendo $10 \mathrm{~mL}$ de suspensão celular da linhagem NB4 ( $5 \times 10^{5}$ células $/ \mathrm{mL}$ cultivadas como já descrito) foram tratadas com 50,100 ou $200 \mathrm{ng} / \mathrm{mL}$ de HF, adicionada diretamente ao meio de cultura. A incubação foi realizada por 6, 12 e 24 horas e, ao final deste período, as células foram estimuladas com $1 \mathrm{ng} / \mathrm{mL}$ de TGF- $\beta 1$ (Sigma Aldrich, St. Louis, MO, EUA) por 1 hora, e retiradas da cultura para extração de proteínas totais. Nesta etapa, as células foram lavadas duas vezes com PBS 1X (2,7 mM KCl, 1,5 mM $\mathrm{KH}_{2} \mathrm{PO}_{4}, 137 \mathrm{mM} \mathrm{NaCl}, 8 \mathrm{mM} \mathrm{Na} 2 \mathrm{HPO}_{4} .7 \mathrm{H}_{2} \mathrm{O}$ ) por centrifugação a $1.500 \mathrm{rpm}, 4^{\circ} \mathrm{C}$ por 10 minutos. O precipitado celular foi dissolvido com $500 \mu \mathrm{L}$ de solução de lise $(20 \mathrm{mM}$ Tris (pH 7,5), $150 \mathrm{mM} \mathrm{NaCl}, 1 \mathrm{mM}$ EDTA, 1mM EGTA, 1\% Triton X-100, 2,5 mM pirofosfato de sódio, 1:100 soluções contendo inibidores de proteases e fosfatases (Sigma) e 1mM PMSF), incubado por 5 minutos a temperatura ambiente, e em seguida submetido a três ciclos de: agitação em vórtex por 20 segundos, sonicador 5 minutos e gelo 15 segundos. Por fim, o lisado resultante foi centrifugado a $13.000 \mathrm{rpm}, 4^{\circ} \mathrm{C}$ por 10 minutos e o sobrenadante utilizado para o ensaio de ELISA.

Neste ensaio, utilizamos o kit PathScan(R) Phospho-Smad2 (Ser465/467) Sandwich ELISA (Cell Signaling Technology, Boston, MA, EUA) seguindo as recomendações e reagentes do fabricante. Os níveis de SMAD2 fosforilada são calculados por uma relação direta com a absorbância apresentada. 


\section{6 - Estudo da modulação da expressão de genes reguladores da apoptose pelo tratamento com HF}

Com o objetivo de identificar quais as vias de apoptose deflagradas por esse tratamento, utilizamos o kit $\mathrm{RT}^{2}$ Profiler $^{\mathrm{TM}}$ PCR Array (SA Biosciences, Frederick, MD, USA). Seguindo a mesma estratégia experimental, foram realizados dois experimentos em placas de cultura de células com 6 poços. Cada poço recebeu $5 \mathrm{~mL}$ da suspensão de NB4 com $5 \times 10^{5}$ células $/ \mathrm{mL}$, e estas, foram tratadas por 6 horas com 50 ou $200 \mathrm{ng} / \mathrm{mL}$ de HF (em duplicata). Após o cultivo, as células foram submetidas à centrifugação para obtenção do precipitado celular, a partir do qual foi extraído o RNA.

\section{Extração de RNA}

Os precipitados celulares foram diluídos em $250 \mu \mathrm{L}$ de PBS e acrescidos de $750 \mu \mathrm{L}$ do reagente monofásico Trizol (Invitrogen, Carlsbad, CA, EUA), homogeneizados e incubados à temperatura ambiente por 5 minutos. Em seguida, foram acrescentados $200 \mu \mathrm{L}$ de clorofórmio, e os tubos agitados por 15 segundos, deixados por 5 minutos à temperatura ambiente e em seguida submetidos à centrifugação a $14.000 \mathrm{rpm}, 4^{\circ} \mathrm{C}$ por 15 minutos. $\mathrm{A}$ adição de clorofórmio separou a fase orgânica (fenol-clorofórmio) e aquosa (contendo RNA). Esta última foi transferida para tubos novos, livres de RNAse, e submetidas à precipitação com adição de $500 \mu \mathrm{L}$ de álcool isopropílico $100 \%$. Após centrifugação a $14.000 \mathrm{rpm}, 4^{\circ} \mathrm{C}$ por 10 minutos e descarte do sobrenadante, o RNA precipitado foi lavado com $1 \mathrm{~mL}$ de etanol $70 \%$ e centrifugado por $14.000 \mathrm{rpm}, 4^{\circ} \mathrm{C}$ por 10 minutos. O sobrenadante foi desprezado por inversão e o precipitado foi diluído em água milli-Q estéril acrescida de Dietilpirocarbonato (DEPC) 0,1\% (Sigma-Aldrich, St. Louis, MO, EUA), um inibidor de RNAse. As amostras obtidas foram mantidas em freezer $-80^{\circ} \mathrm{C}$, até o momento do uso. 


\section{Síntese de cDNA}

Um micrograma do RNA de cada amostra foi convertido em cDNA por meio do kit cDNA High Capacity Archive (Applied Biosystems, Foter City, CA, EUA). O RNA foi incubado com 2,5 $\mu \mathrm{L}$ de tampão $10 \mathrm{X}, 1 \mu \mathrm{L}$ de dNTP mixture $25 \mathrm{X}, 2,5 \mu \mathrm{L}$ de random primers 10X, $1,25 \mu \mathrm{L}$ da enzima Multiscribe Reverse Transcriptase (50 U/ $\mu \mathrm{L}), 0,6 \mu \mathrm{L}$ da enzima RNase Inhibitor $(1 \mathrm{U} / \mu \mathrm{L})$ e acrescido de água milli-Q tratada com DEPC para um volume final de $25 \mu \mathrm{L}$. A reação foi submetida à incubação por 10 minutos a $25^{\circ} \mathrm{C}$ e depois a $37^{\circ} \mathrm{C}$ por 2 horas. $\mathrm{O}$ cDNA resultante foi armazenado a $-20^{\circ} \mathrm{C}$ até o momento do uso.

\section{PCR Array}

Esta técnica utiliza as vantagens da PCR (Polymerase Chain Reaction) em tempo real combinada com a habilidade das técnicas de microarray em detectar a expressão de diferentes genes simultaneamente. Neste ensaio, utilizamos uma placa de 96 poços contendo um painel de diferentes genes relacionados com vias de apoptose celular, como genes da família do TNF, família BCL-2, família das caspases, receptores de morte, p53 e resposta a danos ao DNA, famílias CARD, TRAF e IAP, e ainda, genes relacionados com vias antiapoptóticas. Em cada placa analisamos uma única amostra e o nível de expressão de cada gene que esta amostra apresenta. Os genes constitutivos B2M, HPRT1, RPL13A, ACTB GAPDH já estão incluídos em cada placa e foram utilizados como controles internos.

Para a reação de PCR em Tempo Real utilizamos a tecnologia SYBR Green ${ }^{\circledR}$, na qual o número de cópias amplificadas de um determinado gene é proporcional à fluorescência quantificada pelo equipamento, oriunda da liberação por um fluorocromo. Este fluorocormo encontra-se ligado à dupla fita formada pela associação de uma sonda específica e o cDNA na região do gene de interesse. O número de ciclos de PCR necessários para detectar um sinal acima do limiar (threshold) é chamado de Ct (Cycle threshold), diretamente proporcional à 
quantidade de cópias do gene de interesse. Para normalizar os valores de $\mathrm{Ct}$, de forma a considerar diferenças causadas por quantidades distintas de cDNA utilizadas nas reações, o Ct determinado para uma amostra é subtraído da média dos Cts dos genes constitutivos da mesma amostra, gerando assim o $\Delta \mathrm{Ct}$. Para cada gene, o cálculo relativo do RNA mensageiro foi realizado a partir da diferença entre o $\Delta \mathrm{Ct}$ das amostras tratadas com halofuginona (HF) e o $\Delta \mathrm{Ct}$ apresentado pelas amostras controle, que não receberam tratamento (CTRL). A seguinte equação foi utilizada para este cálculo: mRNA relativo $=2^{-\Delta \Delta \mathrm{Ct}}$, onde $\Delta \Delta \mathrm{Ct}=\Delta \mathrm{Ct}_{\mathrm{HF}^{-}}$ $\Delta \mathrm{Ct}_{\mathrm{CTRL}}$. (sendo que $\Delta \mathrm{Ct}_{\mathrm{HF}}$ e $\Delta \mathrm{Ct}_{\mathrm{CTRL}}$ indicam as diferenças do ciclo limiar de cada gene nas amostras tratadas (HF) e nas amostras controle (CTRL), respectivamente.

Para realização deste ensaio, cada amostra foi processada em duplicata, ou seja, dois experimentos foram realizados para cada uma delas. Cada reação por placa consistiu de: 100 $\mu \mathrm{L}$ do cDNA sintetizado diluído 5X, $1275 \mu \mathrm{L}$ do reagente Master Mix (Applied Biosystems, Foster City, CA, EUA) e $1.173 \mu \mathrm{L}$ água milli-Q estéril para completar um volume de $25 \mu \mathrm{L}$ por pocinho da placa. As condições de amplificação foram: $95^{\circ} \mathrm{C}$ por 10 minutos, seguido de 40 ciclos de $95^{\circ} \mathrm{C}$ por 15 segundos e $60^{\circ} \mathrm{C}$ por 1 minuto. Utilizou-se o equipamento 7500 Real Time PCR System (Applied Biosystems, Foster City, CA, EUA) juntamente com o programa Sequence Detection System V1.3. 


\section{PARTE II - Estudo dos efeitos da halofuginona no modelo in vivo de leucemia promielocítica aguda}

Este estudo foi aprovado pelo Comissão de Ética em Experimentação Animal da Faculdade de Medicina de Ribeirão Preto-USP

\section{7 - Modelo de transplante murino de LPA}

Para elaboração de um modelo in vivo de LPA, células leucêmicas obtidas de camundongos transgênicos PML-RARA (HE et al., 1997) foram transplantadas em camundongos imunodeficientes (NOD/SCID). No modelo murino PML-RAR , os camundongos transgênicos (CTs) expressam o gene de fusão $P M L-R A R A$ humano sob o controle da catepsina $\mathrm{G}(h C G-P M L-R A R A)$, a qual direciona a expressão do oncogene para o compartimento mielóide da medula óssea. Cerca de 10 a 15\% dos animais desenvolvem uma forma de leucemia muito semelhante à LPA humana com 10 a 12 meses de vida. Devido à baixa penetrância e ao longo período de latência do modelo transgênico original, para estudar os efeitos in vivo da halofuginona, optou-se por realizar o transplante de células leucêmicas

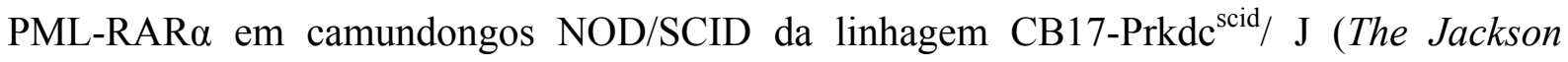
Laboratory, Bar Harbor, USA).

\subsection{1 - Padronização do modelo de transplante e do tratamento com halofuginona}

Quatro experimentos piloto foram realizados com o objetivo de determinar o melhor protocolo de transplante das células $h C G-P M L-R A R A$ em camundongos NOD/SCID. Foram avaliados a mortalidade, a causa da morte (se relacionada à toxicidade da radioterapia ou ao 
tratamento ou pela infiltração leucêmica), o período de latência entre a injeção destas células e as primeiras evidências de infiltração na medula óssea até o desenvolvimento da leucemia.

Nesses quatro experimentos, 14 ou 21 dias após o transplante três animais foram submetidos à eutanásia. O intuito deste método foi iniciar o tratamento com HF após confirmar as primeiras evidências de infiltração da medula óssea por células leucêmicas. Para isto, amostras de sangue e medula óssea foram obtidas e utilizadas para contagem diferencial de células. Além disto, a imunofenotipagem de células da medula óssea foi utilizada para quantificar a porcentagem de células imaturas infiltradas pós-transplante. Foi também realizada extração de DNA de células das suspensões de medula óssea para determinação da expressão do gene de fusão $P M L-R A R A$ por meio de PCR.

Após confirmação do período de latência da infiltração leucêmica, os animais foram divididos em diferentes grupos, sendo grupos de animais tratados com diferentes doses de HF diluída em solução fisiológica $(\mathrm{NaCl} 0,9 \%)$ e outro de animais não tratados (controles) que receberam apenas o veículo. As doses utilizadas foram estabelecidas de acordo com relatos de uso da HF em outros modelos de tumores sólidos e fibrose (SHEFFER et al., 2007; TARAS et al., 2006; XAVIER et al., 2004; GAVISH et al., 2002; MCGAHA et al., 2002) bem como com estudos farmacocinéticos realizados com esta substância (STECKLAIR et al., 2001).

Ao final deste período de tratamento, dois animais de cada grupo foram submetidos à eutanásia por punção intracardíaca após anestesia (cetamina $50 \mathrm{mg} / \mathrm{kg}$ + xilazina $20 \mathrm{mg} / \mathrm{kg}$ ) para obtenção de amostras de sangue e medula óssea. Esse material foi utilizado para análise de remissão hematológica, molecular e imunofenotipagem. Durante e após o período de tratamento, os animais foram observados diariamente, por até 21 dias (final do experimento), ou quando apresentaram sinais de sofrimento (caracterizado por perda de mais de $10 \%$ do peso, dificuldade em se alimentar, desidratação e alteração da pelagem), foram também 
submetidos à eutanásia e procedemos à coleta de amostras como já citado acima. Um esquema geral das variáveis empregadas em cada experimento está resumido na Tabela 1.

Tabela 1 - Quadro resumido das variáveis aplicadas em cada experimento piloto

\begin{tabular}{|c|c|c|c|c|}
\hline Experimento Piloto & $\mathbf{I}$ & II & III & IV \\
\hline Número de animais & 20 & 20 & 20 & 20 \\
\hline Dose Irradiação Co ${ }^{60}$ (cGy) & 200 & 250 & 300 & 250 \\
\hline Tempo antes do tratamento (dias) & 21 & 21 & 14 & 14 \\
\hline Doses de HF ( $\mu \mathrm{g} / \mathrm{kg} / \mathrm{dia})$ & 50 e 250 & 50 e 100 & 150 e 200 & 150 e 200 \\
\hline Tempo de tratamento (dias) & 21 & 21 & 21 & 7 \\
\hline Tempo máximo de sobrevida (dias) & --- & 61 & 41 & 21 \\
\hline
\end{tabular}

\subsection{2 - Transplante de células leucêmicas em camundongos NOD/SCID}

Camundongos NOD/SCID fêmeas entre 10-12 semanas de idade, foram irradiados com dose subletal de 250 cGy (fonte de cobalto) e vinte e quatro horas após a irradiação, células leucêmicas viáveis de CTs $h C G-P M L-R A R A$, previamente armazenadas a $-80^{\circ} \mathrm{C}$, foram preparadas para injeção. Para isto, as células foram descongeladas e imediatamente lavadas por meio de centrifugação a $1.500 \mathrm{rpm}$ a $4^{\circ} \mathrm{C}$ por 5 minutos, utilizando uma solução contendo 50\% de RPMI 1640 (GIBCO, Grand Island, NY, USA) e 50\% de soro bovino fetal (SBF). Em seguida, as células foram diluídas em RPMI 1640 acrescido de 10\% de SBF e os debris presentes foram removidos com auxílio de um cell strainer $(100 \mu \mathrm{m})$. A viabilidade celular na suspensão obtida foi avaliada através de contagem na câmara de Neubauer por exclusão com o corante azul de Tripan. Após uma última lavagem, as células resultantes foram ressuspendidas de tal forma a obter uma diluição contendo um total de $2 \times 10^{6}$ células leucêmicas viáveis de CTs $h C G-P M L-R A R A$ em cada $100 \mu \mathrm{L}$ de suspensão, e este volume foi 
injetado por via intravenosa através do plexo retro-ocular nos camundongos receptores. Esses animais foram mantidos em mini-isoladores, acondicionados em rack com pressão positiva e ar purificado por meio de filtros HEPA, recebendo água e ração autoclavadas ad libitum. O antibiótico neomicina foi adicionado à água $(1 \mathrm{mg} / \mathrm{mL})$, nos primeiros sete dias após o transplante, como tratamento profilático contra possíveis infecções.

\subsection{3 - Tratamentos com a halofuginona}

A partir dos resultados observados nos experimentos piloto, vinte e quatro horas após o transplante os animais começaram a receber a $\mathrm{HF}$ na dose de $150 \mu \mathrm{g} / \mathrm{kg}$ (HF150). Resumidamente, nesse experimento, 40 animais irradiados com dose total de 250 cGy, receberam aproximadamente $2,0 \times 10^{6}$ células $h C G-P M L-R A R A$. Vinte e quatro horas após o transplante, os animais foram divididos em dois grupos: 1) grupo leucêmico controle não tratado (Leu-CT), e 2) grupo tratado com HF na dose de $150 \mu \mathrm{g} / \mathrm{kg}$ (Leu-HF150). O tratamento foi realizado com uma aplicação intraperitoneal por dia, durante vinte e um dias, de HF ou veículo. No final deste período, todos os animais foram submetidos à eutanásia para obtenção de todas as amostras já citadas acima.

Amostras de sangue e medula óssea foram obtidas e utilizadas para confecção de esfregaços e citocentrífuga para análise citomorfológica, respectivamente. Além disto, a imunofenotipagem de células da medula óssea foi utilizada para quantificar a porcentagem de células imaturas. Foi também realizada extração de DNA de células das suspensões da medula óssea para determinação da expressão do gene de fusão $P M L-R A R A$ por meio de PCR. Posteriormente, também foram realizadas análise da produção de TGF- $\beta$ no soro e na medula óssea por meio de ELISA. Ainda, o fator proangiogênico VEGF foi pesquisado por meio de imunohistoquímica em secções da medula, assim como a densidade microvascular (DMV). 
Além disso, a expressão de genes relacionados com a neovascularização e de genes-alvo da via do TGF- $\beta$ foram quantificadas por PCR em tempo real nas amostras de medula óssea. Por fim, para avaliar a toxicidade, amostras de baço, fígado, pulmão, coração, rim e cérebro foram encaminhados para o Laboratório de Patologia da Faculdade de Medicina de Ribeirão Preto. Esses tecidos foram incluídos em parafina e corados com hematoxilina-eosina para análise morfológica. Outro método utilizado para avaliar a toxicidade foi a dosagem sérica das ezimas hepáticas TGO/AST, TGP/ALT, fosfatase alcalina, bem como de creatinina para avaliar possível dano renal. A Figura 1 mostra um esquema resumido de como foram realizados esses experimentos.

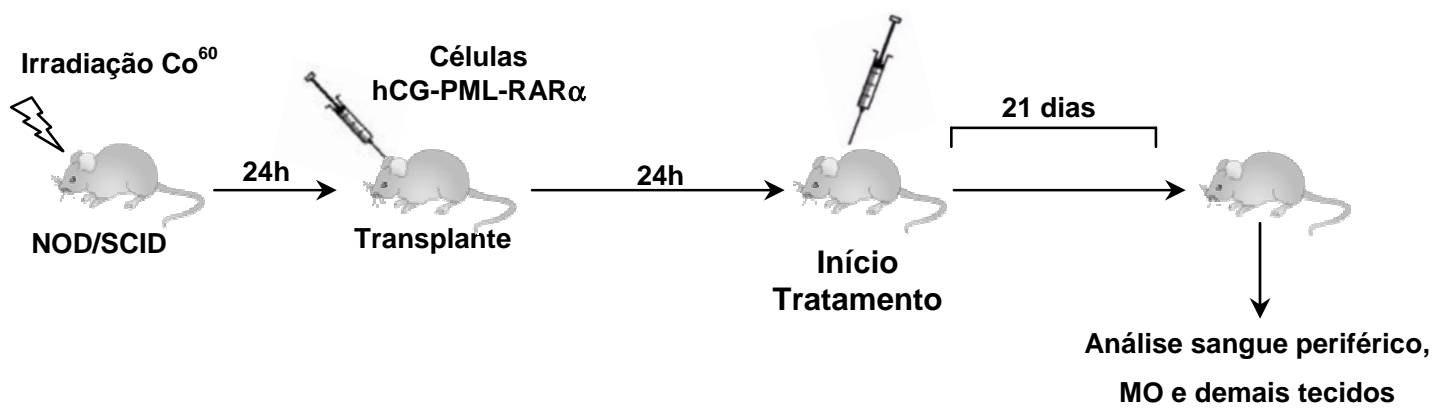

Figura 1 - Esquema geral do experimento. Vinte e quatro horas após a irradiação, os camundongos NOD/SCID receberam células leucêmicas $h C G-P M L-R A R A, 24$ horas depois, os animais foram divididos em dois grupos os quais passaram a receber halofuginona $150 \mu \mathrm{g} / \mathrm{kg}$ (HF150) ou veículo (CT). Ao final de 21 dias de tratamento todos os animais foram sacrificados para análise. 


\section{8 - Análise dos efeitos da Halofuginona no modelo in vivo da LPA}

\subsection{1 - Avaliação da resposta hematológica e molecular}

O acompanhamento da resposta hematológica foi realizado por meio de amostras de sangue da cauda dos camundongos que foram coletadas a cada 10 dias a partir do início do tratamento até o momento da eutanásia. Vinte microlitros foram diluídos 1:9 em PBS 1X contendo citrato de sódio $0,32 \%$ e a determinação do número de leucócitos, dosagem de hemoglobina e número de plaquetas foi realizada em contador automático Coulter STKS. Além disto, foi realizado um esfregaço do sangue periférico, corado com Leishman, para contagem diferencial de leucócitos. Suspensões celulares de medula óssea obtidas após o procedimento de eutanásia foram utilizadas para o preparo de lâminas de citocentrífuga, nas quais também realizamos a contagem diferencial de leucócitos, e extração de DNA para determinação da resposta molecular pela pesquisa do gene $P M L-R A R A$. Sendo assim, células da medula óssea foram removidas por meio de infusão de RPMI 1640 sob pressão (flushing) das cavidades medulares dos fêmures e tíbias e filtradas através de cell strainer. Desta suspensão celular, 80.000 células foram utilizadas para preparação de lâminas de citocentrífuga e aproximadamente $1 \times 10^{6}$ células foram utilizadas para extração de DNA utilizando o kit Puregene $^{\mathrm{TM}}$ (Gentra Systems, Minneapolis, MN, USA). A presença do gene $P M L-R A R A$ foi detectada através de reação de $\mathrm{PCR}$, na qual os primers $\mathrm{C} 1$ e $\mathrm{D}$ e as condições da reação foram utilizados segundo o descrito por van Dongen (VAN DONGEN et al., 1999).

\subsection{2 - Imunofenotipagem de medula óssea}

Com o objetivo de acompanhar a infiltração de células leucêmicas na medula óssea dos camundongos transplantados, uma imunofenotipagem foi realizada para quantificar a 
presença de células mielóides mais imaturas e diferenciadas. Adotamos a marcação na qual selecionamos as células $\mathrm{CD}^{4} 5^{+}$e dentro desta população avaliamos a porcentagem de células $\mathrm{CD}_{117^{+}} / \mathrm{CD}_{16 / 32^{+}}$(GUIBAL et al., 2009), mais imaturas e $\mathrm{CD} 11 \mathrm{~b}^{+} / \mathrm{Gr}-1^{+}$, mais diferenciadas. Utilizamos esses anticorpos marcados com os fluorocromos PercP, PE e FITC (BD Biosciences, San Jose, CA, EUA) respectivamente. Após obtenção das suspensões celulares de medula óssea, aproximadamente $1 \times 10^{6}$ células foram lavadas com PBS $1 \mathrm{X}$ e incubadas com $2 \mu \mathrm{L}$ de cada anticorpo monoclonal (Biosciences Pharmigen, San Diego, CA, USA) por 20 minutos a $4^{\circ} \mathrm{C}$ protegidos da luz. Anticorpos isotipos de especificidade irrelevante conjugados com os mesmos fluorocromos foram utilizados como controles negativos. Os eritrócitos que porventura estavam presentes nas amostras foram lisados imediatamente após marcação com anticorpos por meio de incubação com 2 mL de FACS solução de lise. (Becton Dickinson, San Jose, CA, USA) e incubada por 10 minutos a temperatura ambiente protegidos da luz. Após remover a solução de lise por centrifugação, por fim, as células foram lavadas com $2 \mathrm{~mL}$ de PBS/azida 1\% e centrifugadas por 5 minutos a $1.500 \mathrm{rpm}$ e ressuspendidas em $500 \mu \mathrm{L}$ de PBS/ formaldeído $1 \%$. Um mínimo de 10.000 eventos/ tubo foram adquiridos com citômetro de fluxo FACScalibur. As células CD45 positivas viáveis foram utilizadas para determinar a gate na qual, a porcentagem de cada subgrupo celular foi determinada utilizando o software CellQuest (Becton Dickinson).

\subsection{3 - Análise da resposta clínica ao tratamento}

O peso do baço foi utilizado na avaliação da resposta ao tratamento, uma vez que este órgão é infiltrado por células leucêmicas, e todos animais leucêmicos em modelo de transplante apresentam esplenomegalia (ABREU E LIMA, Tese de Doutorado). Além disso, a sobrevida dos camundongos dos diferentes grupos foi calculada a partir do dia do transplante (tempo “0”) até a morte e expressa em dias. 


\subsection{4 - Análise da toxicidade da halofuginona}

No momento da eutanásia, os animais de ambos os grupos foram anestesiados (cetamina $50 \mathrm{mg} / \mathrm{kg}$ + xilazina $20 \mathrm{mg} / \mathrm{kg}$ ) e fragmentos de baço, fígado, pulmão, coração, rim e cérebro foram obtidos. Essas amostras foram encaminhadas para o Laboratório de Patologia da Faculdade de Medicina de Ribeirão Preto-USP. Esses tecidos foram incluídos em parafina e corados com hematoxilina-eosina para posterior análise morfológica. Para complementar esse estudo, aproximadamente $500 \mu \mathrm{L}$ de sangue foi coletado por punção cardíaca para obtenção de soro. Para isto, o sangue foi incubado a $37^{\circ} \mathrm{C}$ em banho-maria por 15 minutos e em seguida centrifugado por 15 minutos a $3.000 \mathrm{rpm}$ em temperatura ambiente. $\mathrm{O}$ soro obtido foi utilizado para avaliar a toxicidade gerada pela HF neste modelo de leucemia proposto. Desta forma, parâmetros bioquímicos foram analisados segundo protocolo dos fabricantes. TGO/AST (Transaminase Glutâmica Oxalacética/Aspartato Amino Transferase), TGP/ALT (Transaminase Glutâmica Pirúvica/Alanina Amino Transferase) e fosfatase alcalina, utilizadas como indicadores de função hepática, foram dosadas segundo o kit e protocolo da Labtest Diagnóstica S.A. (Lagoa Santa, Minas Gerais, Brasil). E para avaliar a atividade renal a creatinina foi dosada segundo kits e protocolos da fabricante SERA-PAK (Bayer Co. Buenos Aires, Argentina) em analisador bioquímico TECHNICON RA-XTTM System, junto à unidade do Laboratório de Análises Clínicas da Faculdade de Ciências Farmacêuticas de Ribeirão Preto-USP.

\section{9 - Análise da expressão de genes envolvidos com a angiogênese e genes-alvo da via do TGF- $\beta$ por PCR em Tempo Real}

Utilizamos a técnica de PCR em tempo real com o objetivo de analisar os efeitos da halofuginona sobre a expressão de genes relacionados com a vasculogênese, bem como 
analisar a expressão de genes-alvo da via do TGF- $\beta$, que podem estar envolvidos tanto com a angiogênese quanto com controle do ciclo celular. Assim, a expressão dos genes $V E G F A$ e $E G F$ e dos genes-alvo do TGF- $\beta$ : TGFB, SMAD3, SMAD4 e $M Y C$ foram determinadas por PCR em tempo real. As sondas para detecção da expressão destes genes foram desenhadas utilizando-se o sistema Assay on Demand (Applied Biosystems, Foster City, CA, EUA). Os códigos de acesso, as sequências de referência no $N C B I$ e as sondas utilizadas na amplificação dos referidos genes encontram-se resumidos na Tabela 2.

A normalização foi realizada por meio da expressão dos genes constitutivos $G A P D$ e ACTB (Applied Biosystems, Foster City, CA, EUA). A extração de RNA a partir da medula óssea dos camundongos, bem como a síntese de cDNA foram realizadas como já descrito nos ensaios in vitro. A reação de PCR em tempo real foi realizada em um volume final de $10 \mu \mathrm{L}$, utilizando 1,25 $\mu \mathrm{L}$ do cDNA diluído 5 vezes, $0,5 \mu \mathrm{L}$ da sonda fluorescente Taqman ${ }^{\circledR}$ para cada gene e $5 \mu \mathrm{L}$ do reagente MasterMix (Applied Biosystems, Foster City, CA, EUA). As condições de amplificação da reação foram: $95^{\circ} \mathrm{C}$ por 10 minutos, seguidos de 40 ciclos de $95^{\circ} \mathrm{C}$ por 15 segundos e $60^{\circ} \mathrm{C}$ por 1 minuto. Utilizamos o mesmo equipamento e programas de análise já citados.

Tabela 2 - Sondas utilizadas para a amplificação por PCR em Tempo Real de genes envolvidos na angiogênese e genes-alvo do TGF- $\beta$ murinos

\begin{tabular}{ccc}
\hline Gene & $\begin{array}{c}\text { Acesso } \\
\text { www.appliedbiosystems.com.br }\end{array}$ & Código de acesso NCBI \\
\hline VEGFA & Mm00437304_m1 & NM_001025250.3 \\
$E G F$ & Mm00438696_m1 & NM_010113.3 \\
$T G F B$ & Mm03024053_m1 & NM_011577.1 \\
SMAD3 & Mm00489638_m1 & NM_016769.2 \\
$S M A D 4$ & Mm03023996_m1 & NM_008540.2 \\
$M Y C$ & Mm00487804_m1 & NM_010849.4 \\
\hline
\end{tabular}

Estão ilustrados os códigos de acesso no site www.appliedbiosystems.com.br e os códigos de referência no $N C B I$ das sondas utilizadas nas reações de PCR em tempo real. 


\subsection{0 - Quantificação da expressão de TGF- $\beta$ no soro e medula óssea dos camundongos transplantados por meio de ELISA}

Para quantificar a citocina TGF- $\beta$, realizamos o ensaio imunoenzimático (ELISA) a partir de amostras de camundongos leucêmicos tratados ou não com HF. Ao final de 21 dias de tratamento, os animais foram submetidos à eutanásia, e amostras de soro e medula óssea foram obtidas.

As amostras de soro foram preparadas a partir do sangue total como já descrito na seção 3.8.4 e as suspensões de medula óssea foram obtidas como descrito em 3.8.1. Aproximadamente $5 \times 10^{6}$ células foram utilizadas para extração de proteínas totais e este procedimento foi realizado como já descrito na seção 3.5. O extrato protéico total resultante foi também armazenado em freezer $-80^{\circ} \mathrm{C}$ até o momento do uso e posteriormente utilizado para os ensaios de ELISA.

Primeiramente, para a quantificação do TGF- $\beta 1$, as amostras de soro e medula óssea foram submetidas à ativação da forma latente dessa citocina por meio de acidificação. Resumidamente, foi adicionado $\mathrm{HCl} 1 \mathrm{~N}$ a 1:4 para soro e 1:5 para medula óssea, as amostras foram incubadas a temperatura ambiente por 10 minutos e, em seguida, neutralizadas com $\mathrm{NaOH}$ 1,2N/ HEPES 0,5M nas proporções 1:6 e 1:9 respectivamente. Nestes ensaios, utilizamos o kit Quantikine ${ }^{\circledR} T G F-\beta 1$ Immunoassay (RD Systems, Minneapolis, MN, EUA) seguindo as recomendações e reagentes do fabricante. O procedimento teve início com a adição de $50 \mu \mathrm{L}$ de diluente específico em cada poço da placa de ELISA, seguida pela adição do mesmo volume de cada amostra, dos controles e dos padrões. A placa foi então incubada a temperatura ambiente por 2 horas, seguida por quatro ciclos de lavagem. Procedeu-se com a adição de $100 \mu \mathrm{L}$ do anticorpo conjugado com avidina-peroxidase e mais um período de incubação de 2 horas a temperatura ambiente. Após mais 4 ciclos de lavagem, adicionou-se $100 \mu \mathrm{L}$ de solução de substrato, incubou-se 30 minutos no escuro e por fim adicionou-se 100 $\mu \mathrm{L}$ de solução de parada da reação. A leitura óptica foi realizada a $450 \mathrm{~nm}$. Os níveis de TGF$\beta 1$ são demonstrados em concentração pg/ $\mathrm{mL}$. 


\subsection{1 - Análise da expressão do VEGF e da densidade microvascular em biópsias de medula óssea dos camundongos leucêmicos}

Com o intuito de confirmar a importância da angiogênese na LPA e verificar o potencial antiangiogênico da halofuginona, avaliamos por meio de imunohistoquímica secções de medula óssea dos animais leucêmicos, tratados ou não com HF. As biópsias de medula óssea foram obtidas após eutanásia e submetidas à análise da expressão de VEGF, bem como da DMV por meio da identificação da expressão de CD34 no endotélio dos vasos.

Para as reações de imunohistoquíca, foram utilizados os anticorpos primários antiVEGF (Santa Cruz Biotechnology, Santa Cruz, CA, EUA) e anti-CD34 (BD Biosciences, San Jose, CA, EUA) murinos, bem como os anticorpos secundários biotinilados específicos antiIgG2a (Sigma-Aldrich, St. Louis, MO, EUA). As amostras foram incluídas em uma solução de formol 10\% tamponado, não mais do que 48 horas. Primeiramente, as lâminas silanizadas foram preparadas a partir de blocos de parafina. Em seguida, estas foram desparafinadas com xilol, hidratadas com água destilada e submetidas aos procedimentos de recuperação antigênica com tampão citrato, bloqueio da peroxidase endógena com peróxido de hidrogênio a $3 \%$, permeabilização celular com salina tamponada/triton $0,5 \%$ e incubação com soro de cavalo 1:50 durante 1 hora à temperatura ambiente. Posteriormente, a incubação com os anticorpos primários anti-VEGF (1:500) e anti-CD34 (1:50), diluídos em BSA 1\% foi realizada a $4^{\circ} \mathrm{C}$ overnight. Após três lavagens com PBS, o anticorpo secundário (1:200), também diluído em BSA $1 \%$, foi adicionado às lâminas durante 1 hora à temperatura ambiente. Em seguida, as lâminas foram novamente lavadas com PBS e incubadas com o complexo avidina-biotina durante 30 minutos à temperatura ambiente. A reação de imunohistoquímica foi revelada com solução constituída pelo reagente Diamino-benzidina (DAB, Sigma-Aldrich, St. Louis, MO, EUA), PBS e peróxido de hidrogênio durante 1 
minuto. Por fim, as lâminas foram coradas com hematoxilina de Harris, submetidas aos processos de desidratação, fixação e montagem.

A análise da expressão do VEGF e da DMV nas células da medula óssea foi realizada por meio da visualização microscópica de três campos de 400X. Nesses campos, foram contadas as células da medula óssea e o número de microvasos $/ \mathrm{mm}^{2}$. A expressão do VEGF foi analisada de forma quantitativa, determinando-se a porcentagem de células positivas nos três campos pesquisados e de qualitativamente avaliando-se a intensidade de expressão como: negativa $(-)$, fraca $(+)$, moderada $(++)$ ou forte $(+++)$.

\subsection{2 - Análise Estatística}

Todas as análises foram realizadas com o auxílio do programa GraphPad InStat (GraphPad, San Diego, CA, EUA). A comparação entre os diferentes grupos quanto à expressão de BCL-2, quantificação de P-SMAD2, os valores de hemoglobina, contagem de leucócitos e de plaquetas no sangue periférico e o peso relativo do baço foi feita por análise de variância (ANOVA) seguido pelo pós-teste de Bonferroni’s (quando comparamos 3 ou mais grupos).

Nas análises de apoptose, proliferação, ciclo celular, contagem de células imaturas no sangue periférico e na medula óssea e a dosagem de enzimas no soro, as comparações entre os diferentes grupos de tratamento (quando comparamos dois grupos) foi realizada por meio de test $t$ de Student não pareado.

Os tempos de sobrevida foram analisados pelo método de Kaplan-Mayer e a comparação entre os dois grupos de tratamento foi feita pelo test de log-rank.

As diferenças foram consideradas significativas se o valor de $p$ foi igual ou maior que 0,05 . 
4-Resultados 


\section{PARTE - I: Análise in vitro dos efeitos da halofuginona na LPA}

\section{1 - Ensaios de proliferação celular e apoptose}

\subsection{1 - Estudo do ciclo celular por incorporação de BrdU e marcação com 7-AAD}

Para caracterizar os efeitos da halofuginona sobre a proliferação e apoptose em células NB4, uma linhagem de LPA, o ensaio de BrdU foi realizado após tratamento das culturas com concentrações de 50, 100 e $200 \mathrm{ng} / \mathrm{mL}$ de HF por 12, 24 e 48 horas.

Nesses experimentos, observou-se que a halofuginona foi capaz de diminuir de maneira dose-dependente o número de células na fase de síntese (fase $\mathrm{S}$ ) do ciclo celular, ou seja, células que estão em proliferação (Figura 2). A porcentagem de células em fase $\mathrm{S}$ foi muito semelhante nas amostras tratadas por 12 ou 24 horas, principalmente com as concentrações de 100 e $200 \mathrm{mg} / \mathrm{mL}$. A partir de 24 horas de tratamento, a diminuição da proliferação celular foi ainda mais acentuada, mesmo na menor concentração utilizada (Figura 3A). Em comparação com as amostras não tratadas, a halofuginona reduziu a proliferação celular em até $94,93 \%(2,093 \pm 0,304$ vs. $41,21 \pm 3,25)$ após 48 horas de tratamento $(\mathrm{p}<0,0001)$.

A diminuição de células em proliferação após o tratamento com HF foi associado ao aumento da porcentagem de células em fase $\mathrm{G} 0 / \mathrm{G} 1 \quad(\mathrm{p}=0,0003)$, sugerindo que houve bloqueio na progressão do ciclo celular na transição G1/S. Na Figura 3C podemos observar o aumento de células em G0/G1 acompanhando o aumento da concentração de HF após 12 horas de incubação.

Além do bloqueio do ciclo celular, um marcante aumento no número de células em apoptose foi observado, também de forma dose-dependente, e principalmente após 48 horas 
de tratamento (Figura 3B). Após o tratamento durante 12 horas, a halofuginona foi capaz de aumentar em 1,7 vezes o número de células em apoptose $(12,53 \pm 1,53$ vs. 21,95 $\pm 0,79$; $\mathrm{p}=0,0007$ ). Após um período maior de incubação, a apoptose aumentou até 5 vezes em relação às células que não foram tratadas $(\mathrm{p}=0,0059)$.

No conjunto, os resultados demonstram que a HF foi capaz de inibir a proliferação celular e induzir a apoptose na linhagem NB4.

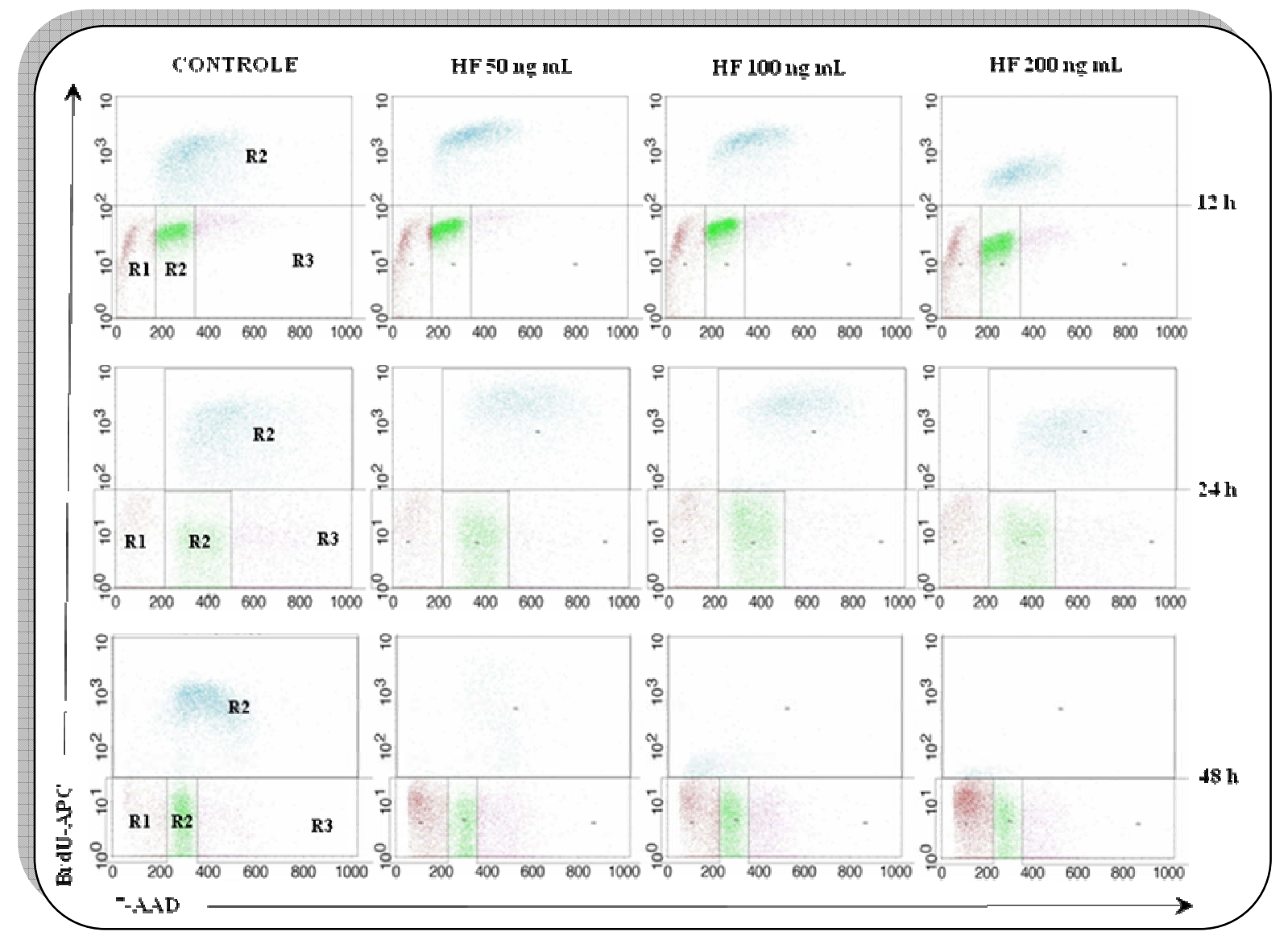

Figura 2 - Análise por citometria de fluxo dos efeitos da halofuginona sobre o ciclo celular nas células NB4 por meio da marcação com BrdU e 7-AAD. Os gráficos de pontos mostram a marcação com BrdU no eixo $\mathrm{Y}$ e com 7-AAD no eixo $\mathrm{X}$ de amostras incubadas com diferentes concentraçãos de HF (indicadas nas bordas superiores). Os gráficos à esquerda mostram os resultados nas amostras controle não tratadas nos diferentes tempos. Quadrante R1, em vermelho, células apoptóticas correspondentes ao pico sub G0/G1; quadrante R2, em verde, células em G0/G1; R3, em vermelho escuro, células G2+M; R4, em azul, células em fase $\mathrm{S}$. 
A

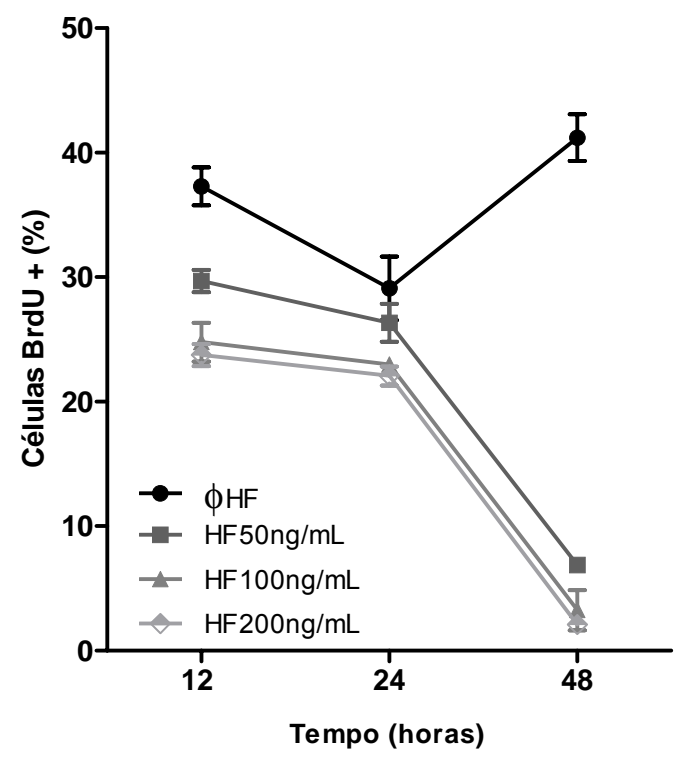

C

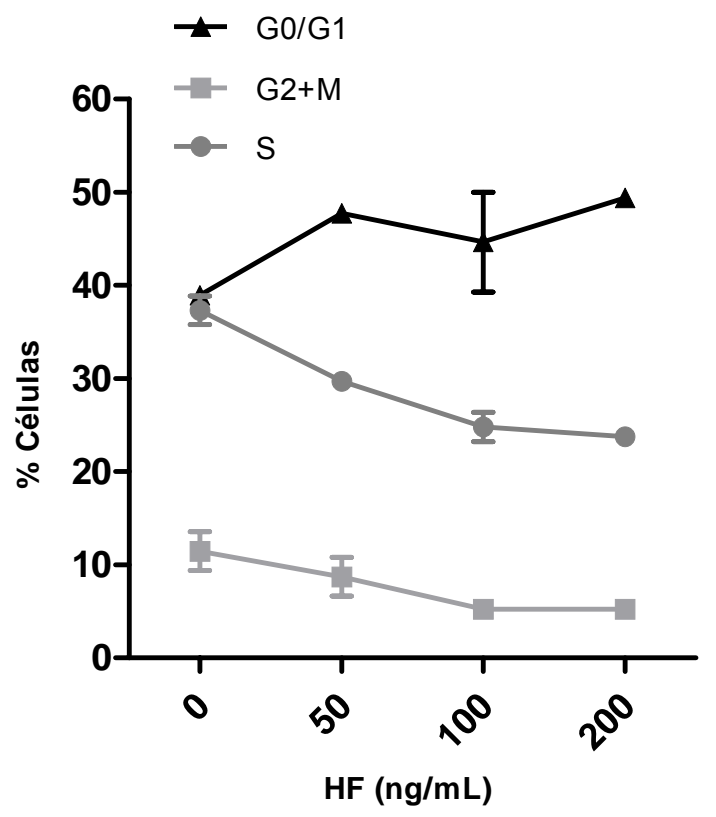

B

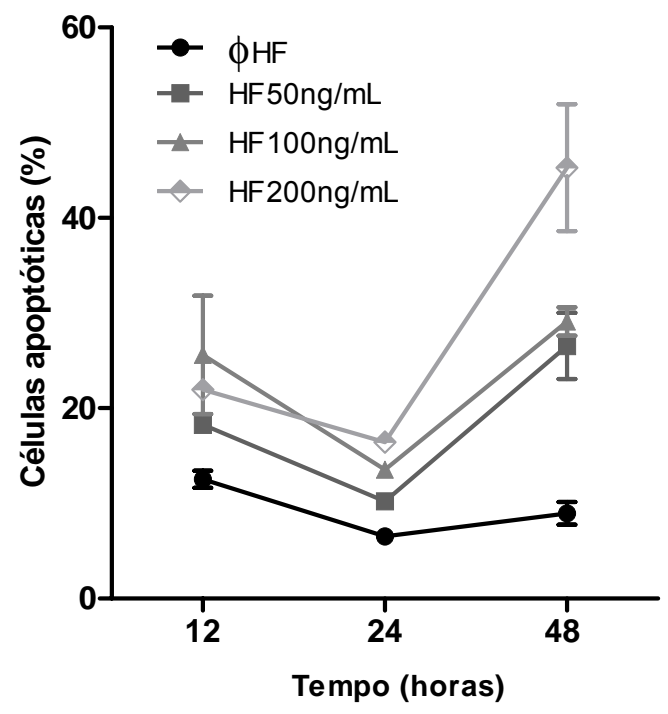

Figura 3 - Efeitos da HF sobre o ciclo celular nas células NB4. As células foram incubadas com concentrações crescentes de $\operatorname{HF}(0,50,100$ e $200 \mathrm{ng} / \mathrm{mL}$ ) durante 12,24 e 48 horas seguida pelo estudo do ciclo celular por meio do ensaio de BrdU. No gráfico A: porcentagem de células $\mathrm{BrdU}+$ é indicada como células na fase $\mathrm{S}$ do ciclo celular (prolieferação). Gráfico B: indica a porcentagem de células em apoptose (BrdU -). Gráfico C: porcentagem de células em diferentes estágios do ciclo celular, G0/G1, G2+M e S após 12 horas de tratamento com HF. Os resultados indicam a média e o desvio padrão de três experimentos independentes. 


\subsection{2 - Expressão da proteína BCL-2}

Com objetivo de determinar se a ação pró-apoptótica da HF estava associada à regulação da proteína BCL-2, analisamos sua expressão nas mesmas amostras usadas no ensaio de incorporação de BrdU (Figura 4). Através da dupla marcação BrdU e BCL-2 foi possível detectar a diminuição da expressão desta proteína, de forma dose-dependente, correlacionando-se com a diminuição de células positivas para o BrdU. Após 48 horas de tratamento a expressão da BCL-2 foi quase nula $(\mathrm{p}<0,0001)$ (Figura 5).

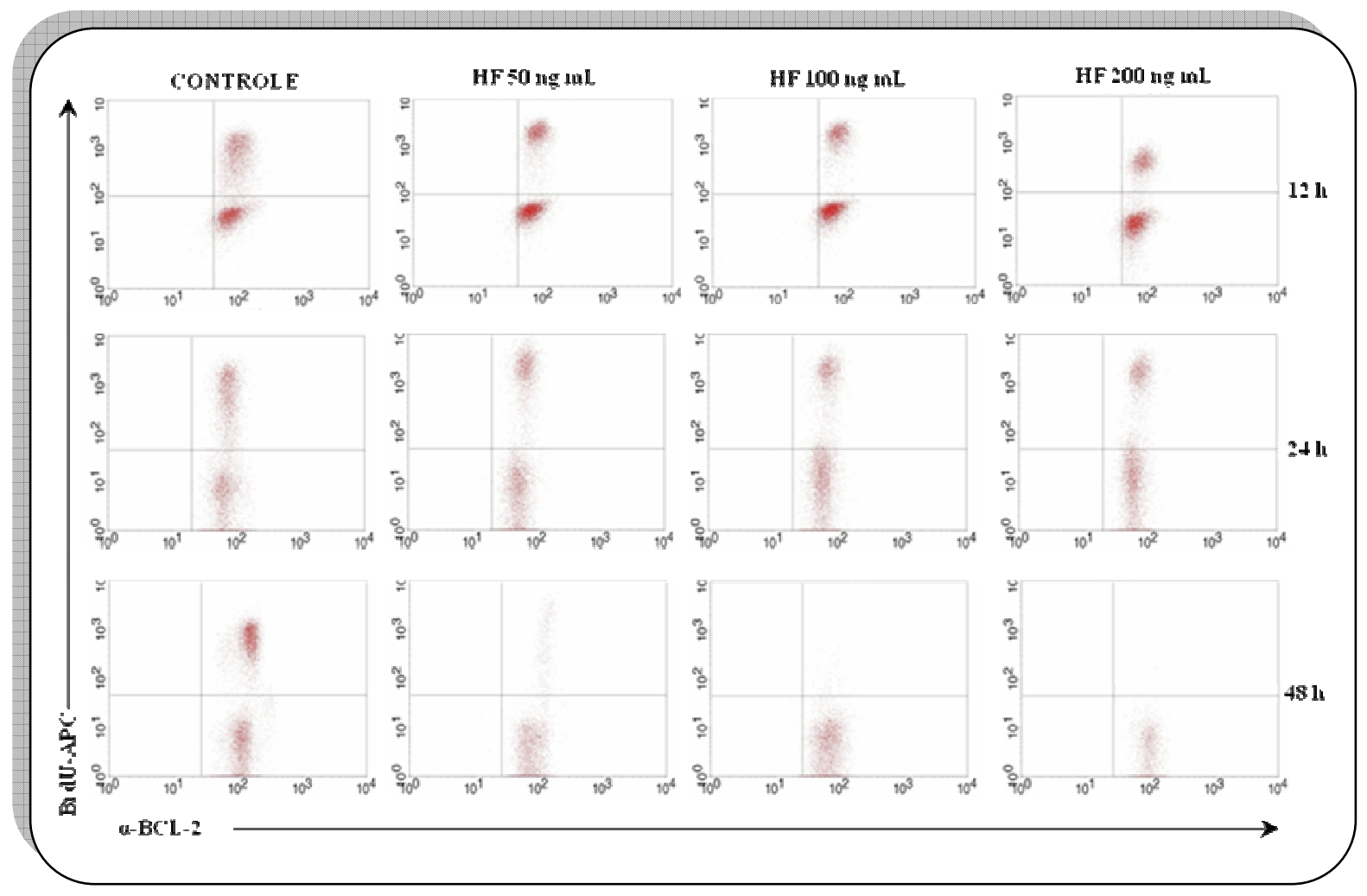

Figura 4 - Análise por citometria de fluxo dos efeitos da halofuginona sobre a expressão de BCL-2 nas células NB4. Os gráficos de pontos mostram a marcação com BrdU no eixo $Y$ e para o BCL-2 no eixo X de amostras incubadas com diferentes concentrações de halofuginona (indicadas nas bordas superiores). Os gráficos à esquerda mostram os resultados nas amostras controles não tratadas nos diferentes tempos. Em cada dot plot, a expressão de BCL-2 foi analisada no quadrante superior direito que corresponde às células viáveis $\left(\mathrm{BrdU}^{+}\right)$e $\mathrm{BCL}-2^{+}$. 


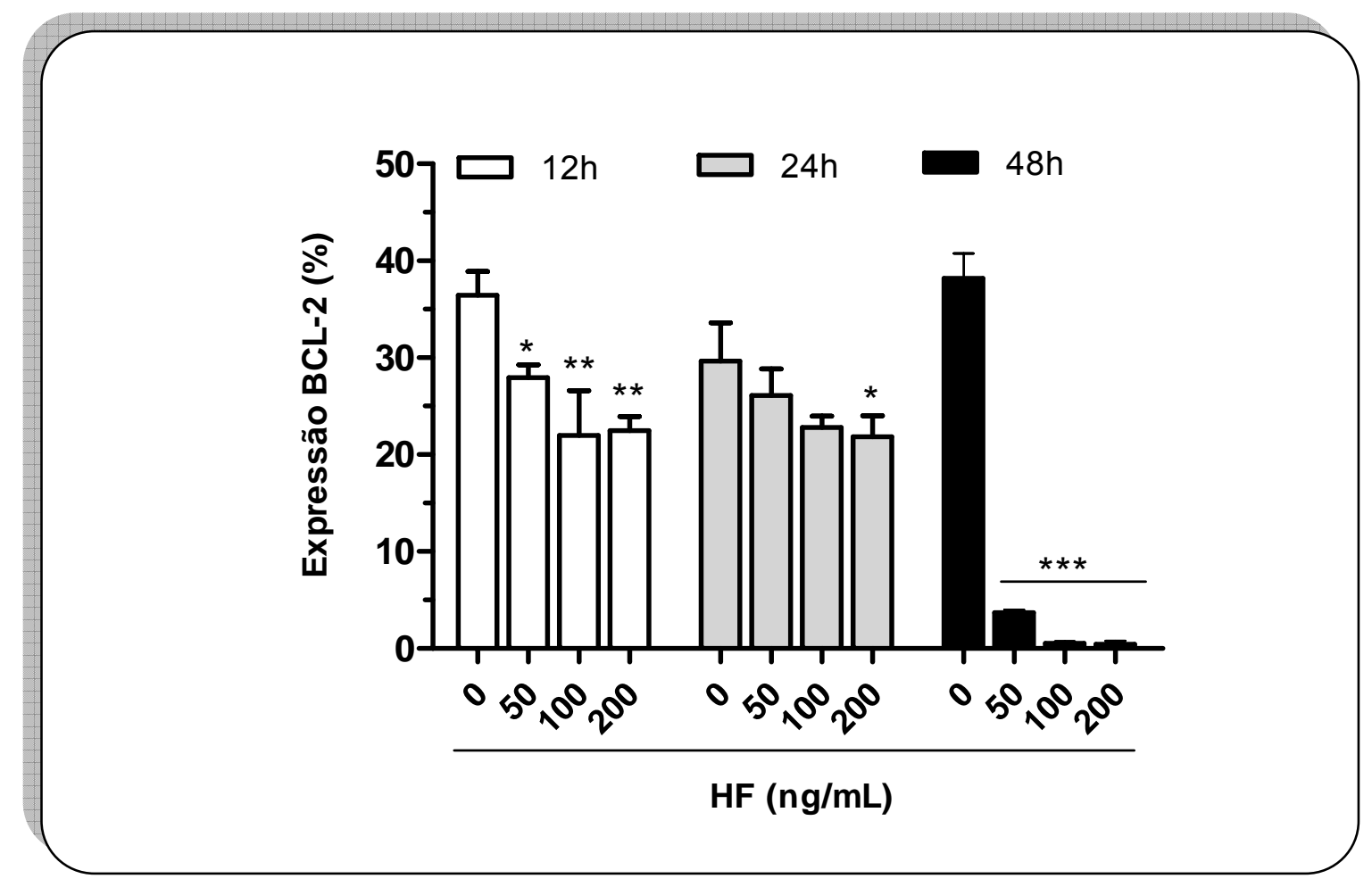

Figura 5 - Efeito da halofuginona sobre a expressão da proteína anti-apoptótica BCL-2 nas células NB4. O gráfico ilustra a porcentagem de expressão da proteína BCL-2 em células NB4 após tratamento com concentrações crescentes de halofuginona durante 12, 24 e 48 horas. A porcentagem de células BCL-2 positivas é exibida como valor da média \pm o desvio padrão referente a três experimentos.

\section{2- Quantificação da SMAD2 fosforilada por meio de ensaio imunoenzimático (ELISA)}

Como a HF foi capaz de inibir a proliferação de células NB4 e induzir a apoptose, procuramos entender se esses efeitos estavam relacionados com a ativação da via do TGF- $\beta$. Após tratar células NB4 com HF nas concentrações de 50, 100 e $200 \mathrm{ng} / \mathrm{mL}$ por 6,12 e 24 horas, a via do TGF- $\beta$ foi estimulada por meio da adição desta citocina diretamente no meio na concentração de $1 \mathrm{ng} / \mathrm{mL}$. As células foram lisadas e o extrato protéico total utilizado para quantificar o nível de P-SMAD2 por meio do ensaio de ELISA.

Conforme ilustrado na Figura 6, a HF inibiu a sinalização através desta via, por meio da inibição da fosforilação do mediador SMAD2. Esta ação ocorreu de forma dosedependente, sendo mais acentuada após 24 horas $(\mathrm{p}<0,0002)$. Dois controles foram utilizados: 
células não tratadas com HF e não estimulada com TGF- $\beta$, e células não tratadas com HF, mas estimuladas com TGF- $\beta$ por 1 hora. A análise do primeiro controle demonstrou que não houve fosforilação da SMAD2 na ausência do estímulo exógeno. Enquanto que a análise do segundo demonstrou qual o nível de concentração da SMAD2 fosforilada após estímulo com a citocina.

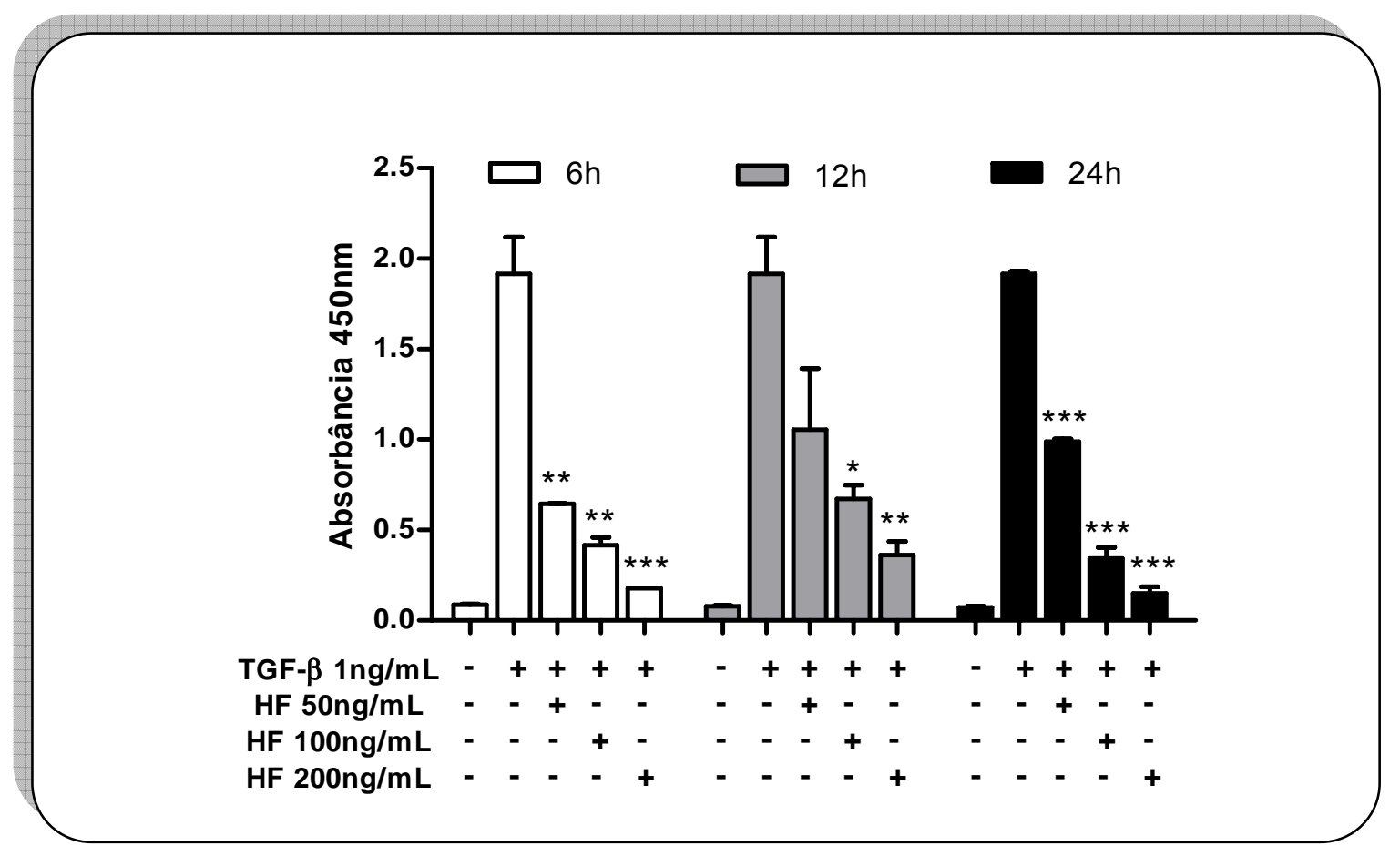

Figura 6 - Análise dos efeitos da HF sobre a fosforilação da SMAD2 em células NB4. As células foram incubadas com crescentes concentrações de $\operatorname{HF}(50,100$ e $200 \mathrm{ng} / \mathrm{mL})$ durante 6,12 e 24 horas e estimuladas ou não com TGF- $\beta(1 \mathrm{ng} / \mathrm{mL})$. A absorbância está diretamente relacionada com o nível de P-SMAD2 presente na amostra. Os resultados indicam a média e o desvio padrão de três experimentos independentes. 


\section{3 - Pesquisa das vias de apoptose alteradas pelo tratamento com HF por meio de PCR array}

A partir da observação dos efeitos da halofuginona sobre o ciclo celular e apoptose, procuramos identificar quais as vias de apoptose podem ser disparadas pelo tratamento com esta susbtância. Para isto, utilizamos o kit $\mathrm{RT}^{2}$ Profiler $^{\mathrm{TM}}$ PCR Array (SA Biosciences, Frederick, MD, USA). Cada tratamento com halofuginona foi realizado em duplicata, e a média dos Cts obtidos foram utilizadas para cálculo do fold change $\left(2^{-\Delta \Delta \mathrm{Ct}}\right)$.

Após análise de todos os genes disponíveis nesse método, aqueles que apresentaram nível de expressão $\left(2^{-\Delta \Delta C t}\right)$ no mínimo duas vezes maior em relação às amostras não tratadas foram selecionados e estão apresentados na Figura 7. O tratamento de células NB4 com halofuginona afetou, de forma geral, principalmente a expressão de genes da família do TNF e das caspases. O tratamento com $50 \mathrm{ng} / \mathrm{mL}$ de halofuginona resultou no aumento da expressão de genes como CD70, TNFSF9, TNFRSF10B, CD40 e FAS. Por outro lado, a concentração de 200 ng/mL além de aumentar a expressão dos genes citados acima, aumentou a expressão de outros genes relacionados com esta via como: TNF, TNFSF10 e LTA $(\mathrm{p}<0,0001)$

Com relação aos genes envolvidos com a via das caspases, o tratamento com halofuginona na concentração de $200 \mathrm{ng} / \mathrm{mL}$ foi capaz de estimular a expressão de diferentes genes, como: CASP10, CASP3, CASP4, CASP6, CFLAR e principalmente CASP8 (p<0,0221). 


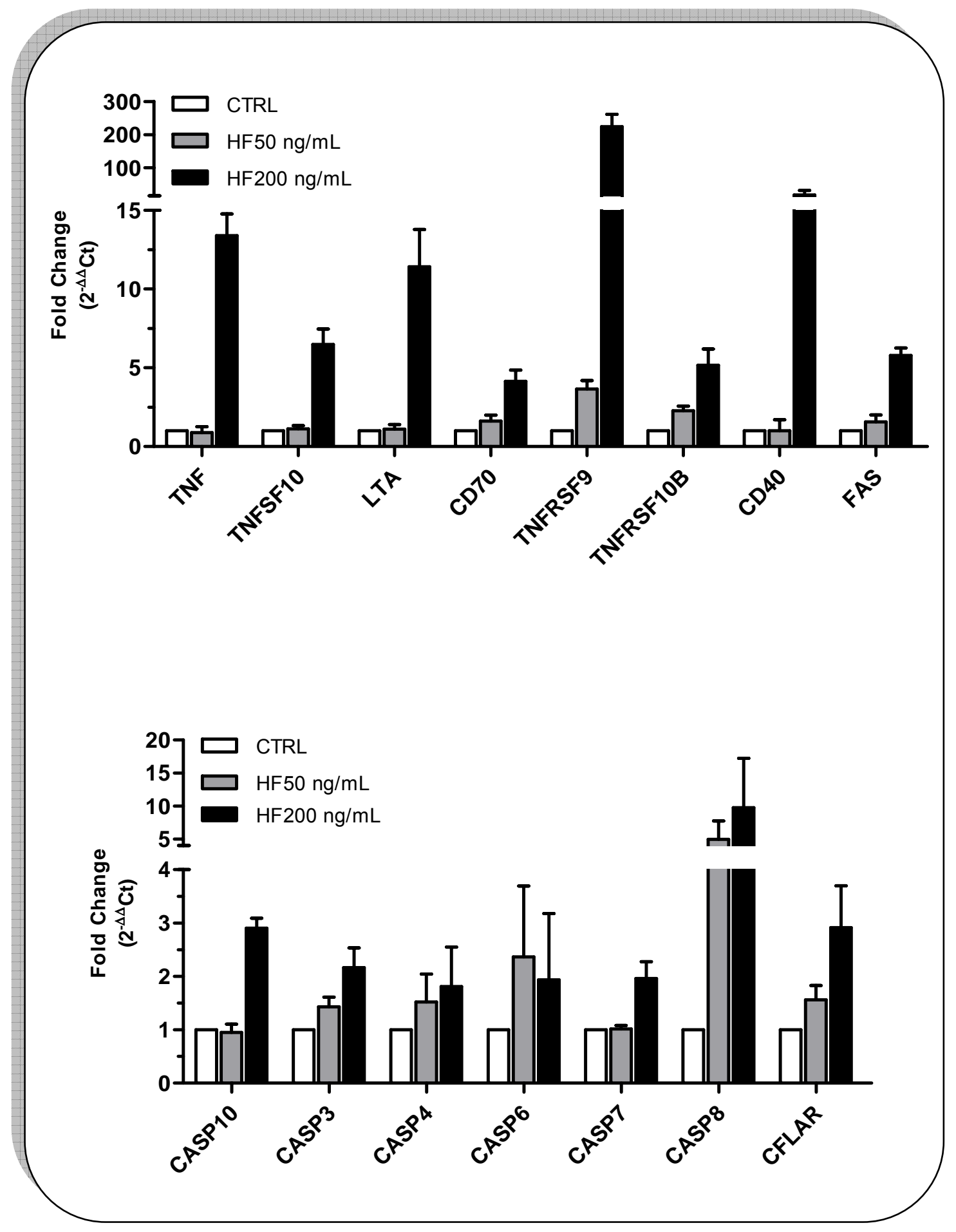

Figura 7 - Expressão de genes envolvidos com apoptose após tratamento com HF. Análise realizada pelo método de PCR Array em células NB4 tratadas com 50 e $200 \mathrm{ng} / \mathrm{mL}$ de halofuginona. No eixo $\mathrm{Y}$ estão indicados os valores de expressão gênica e no eixo $\mathrm{X}$ os genes que apresentaram alterações de pelo menos duas vezes a expressão em relação às células não tratadas com halofuginona (Fold Change $=1$ ). 


\section{PARTE II - Estudo dos efeitos da halofuginona no modelo in vivo de leucemia promielocítica aguda}

Baseados nos resultados observados em quatro experimentos piloto, optamos por um protocolo no qual o tratamento com HF foi iniciado 24 horas após o transplante de células leucêmicas em camundongos NOD/SCID. Nos transplantes realizados anteriormente, a progressão da leucemia ocorreu de forma muita rápida, o período entre as primeiras evidências de infiltração da medula óssea e o óbito foi muito curta, o que dificultou a observação dos efeitos da HF. Por outro lado, nestes experimentos fomos capazes de definir a dose de tratamento de $150 \mu \mathrm{g} / \mathrm{kg}$ de HF por 21 dias, uma vez que doses superiores resultaram em grande toxicidade e doses menores não forneceram nenhum indício de remissão hematológica.

Sendo assim, no experimento realizado, ao final de 21 dias de tratamento, 5 animais de cada grupo sobreviveram (Leucêmicos controle, os quais não foram tratados: Leu-CT; e Leucêmicos tratados com HF: Leu-HF150). Estes animais foram submetidos à eutanásia por meio de punção cardíaca, após anestesia, e as amostras biológicas obtidas foram utilizadas para avaliar os potenciais efeitos da halofuginoa sobre a LPA neste modelo.

\section{4 - Avaliação da resposta hematológica}

Amostras de sangue da cauda dos camundongos foram coletadas no início e no final do período de tratamento com o objetivo de avaliar a resposta hematológica. Podemos observar que antes do transplante das células leucêmicas, os animais dos diferentes grupos apresentavam valores de leucócitos, hemoglobina e plaquetas semelhantes ao animal não irradiado e não transplantado (NOD/SCID). Após o período de 21 dias do transplante, os 
animais que não receberam tratamento com HF (Leu-CT) apresentaram leucocitose acentuada $(p<0.0001)$, anemia $(p<0.0001)$ e plaquetopenia $(p<0.001)$. Esses achados corroboram com os resultados do hemograma apresentados por camundongos transgênicos hCG-PML-RAR $\alpha$ quando leucêmicos (He, et al., 1997). Por outro lado, os animais tratados com HF na dose de $150 \mu \mathrm{g} / \mathrm{kg}$ (Leu-HF150), durante o mesmo período, apresentaram menor número de leucócitos em relação aos animais não tratados $(p<0.001)$, maiores níveis de hemoglobina $(\mathrm{p}<0.05)$ e maior número de plaquetas $(\mathrm{p}=0.0070)$, sendo que esses valores apresentaram-se próximos aos parâmetros de normalidade (NOD/SCID) (Tabela 3).

Tabela 3 - Hemograma: Contagem de leucócitos, plaquetas e dosagem de hemoglobina do sangue periférico dos camundongos NOD/SCID transplantados com células leucêmicas, tratados ou não com halofuginona.

\begin{tabular}{cccccc}
\hline \hline & \multicolumn{2}{c}{ Pré-transplante } & \multicolumn{2}{c}{ Leucêmicos } \\
\cline { 2 - 6 } & NOD/SCID & CT & HF150 & CT & HF150 \\
$\begin{array}{c}\text { Leucócitos } \\
(\mathbf{x 1 0} / \boldsymbol{\mu L})\end{array}$ & $2,33 \pm 0,57$ & $2,52 \pm 1,39$ & $2,0 \pm 4,71$ & $20,6 \pm 21,9$ & $4,2 \pm 3,89$ \\
$\begin{array}{c}\text { Hemoglobina } \\
(\mathbf{g} / \mathbf{d L})\end{array}$ & $15,3 \pm 0,6$ & $12,68 \pm 1,42$ & $13,21 \pm 0,92$ & $9,6 \pm 1,67$ & $12,0 \pm 1,40$ \\
$\mathbf{P l a q u e t a s}_{(\mathbf{1 0} / \boldsymbol{\mu L})}$ & $1.160,0$ & $1.196,8$ & $1.046,8$ & 552,0 & 932,0 \\
\hline 215,9 & $\pm 378,9$ & $\pm 132,6$ & $\pm 83,2$ & $\pm 122,5$ \\
\hline \hline
\end{tabular}

Valores representam a média de cada grupo \pm desvio padrão. NOD/SCID: camundongos não transplantados e não tratados; CT camundongos NOD/SCID transplantados com células leucêmicas e não tratados; HF150: camundongos NOD/SCID transplantados com células leucêmicas e tratados com HF $150 \mu \mathrm{g} / \mathrm{kg}$ por 21 dias.

A análise morfológica dos esfregaços de sangue periférico corados com Leishman, demonstrou que os animais que não receberam tratamento após o transplante apresentaram maior porcentagem de células imaturas em relação aos animais tratados $(36,5 \pm 21,04$ vs. $15 \pm$ $5,09 \%)$.

A análise morfológica da medula óssea foi realizada usando lâminas de citocentrifuga confeccionadas a partir de suspensões celulares de medula óssea. A contagem realizada com 200 células em cada lâmina (Figura 8) evidenciou maior presença de células com 
características de imaturidade nas amostras dos animais não tratados em relação aos animais que receberam $\operatorname{HF}(66,3 \pm 17,9$ vs. $27 \pm 9,3 ; p=0.0037)$. O gráfico na figura 9 ilustra a comparação da porcentagem de células imaturas entre os esfregaços de sangue periférico e citocentrífuga de suspensões de medula óssea.
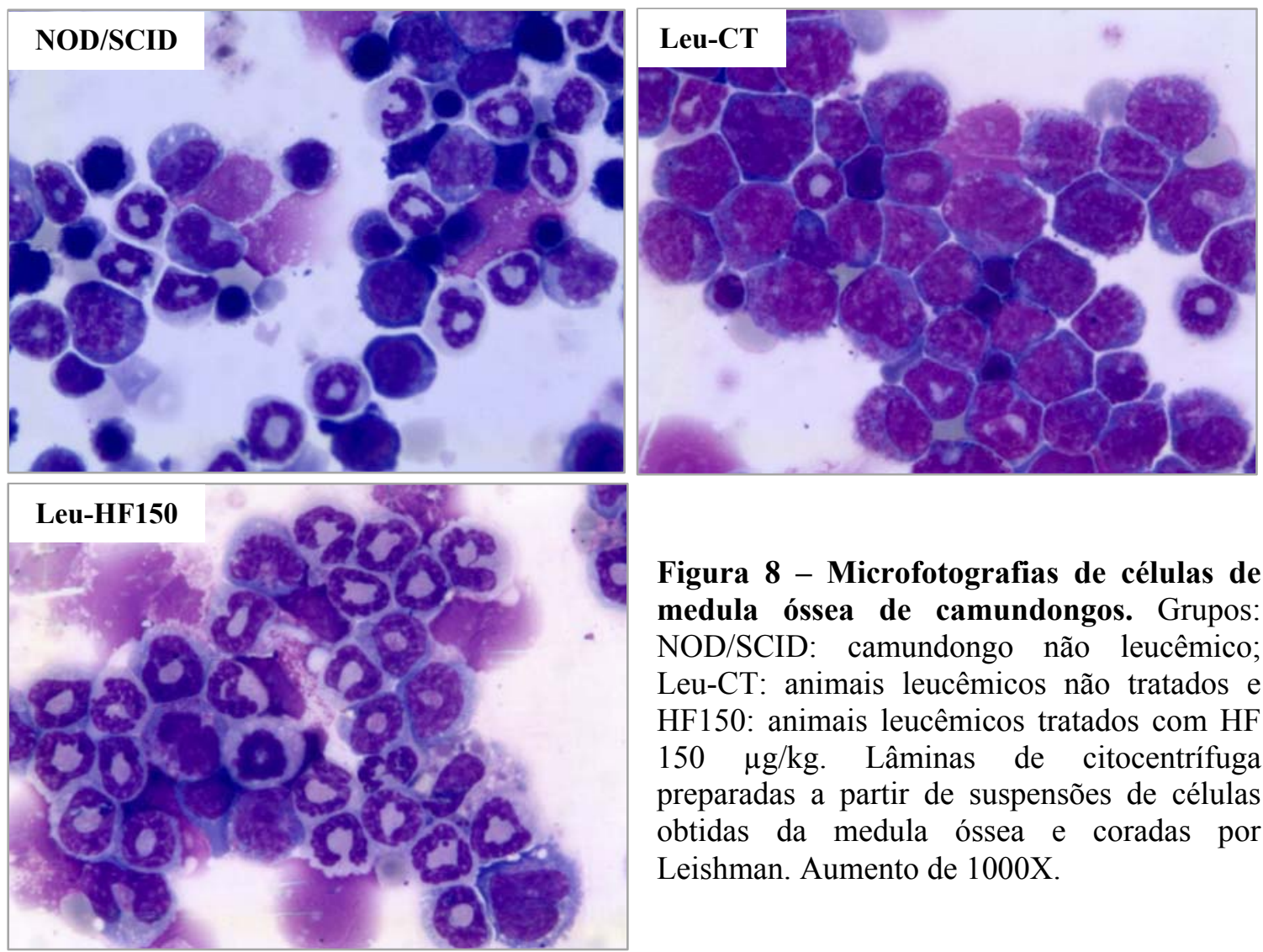

Figura 8 - Microfotografias de células de medula óssea de camundongos. Grupos: NOD/SCID: camundongo não leucêmico; Leu-CT: animais leucêmicos não tratados e HF150: animais leucêmicos tratados com HF $150 \mu \mathrm{g} / \mathrm{kg}$. Lâminas de citocentrífuga preparadas a partir de suspensões de células obtidas da medula óssea e coradas por Leishman. Aumento de 1000X. 


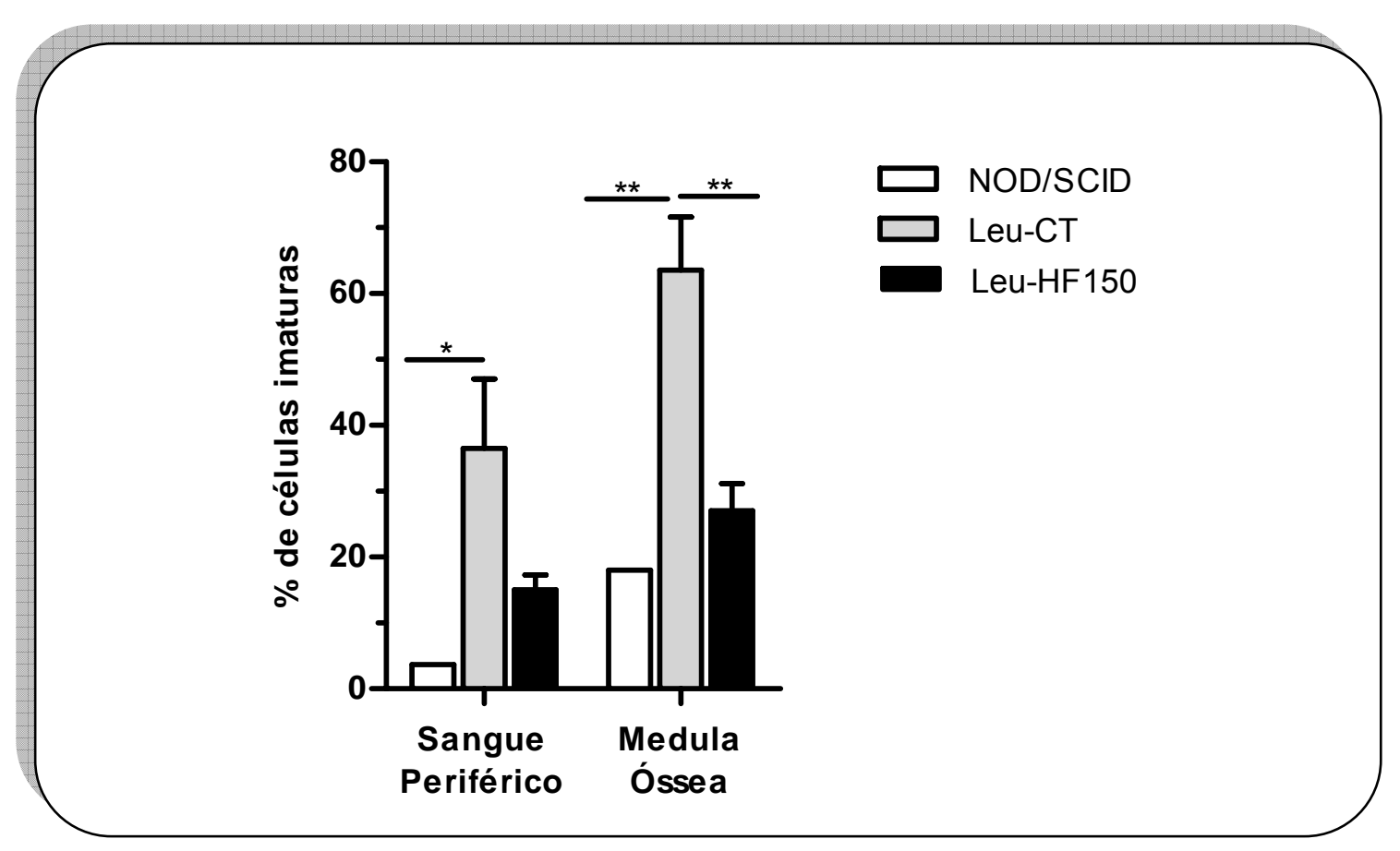

Figura 9 - Porcentagem de células imaturas: análise do sangue periférico e medula óssea dos camundongos segundo os diferentes grupos: NOD/SCID: camundongo não leucêmico; Leu-CT: animais leucêmicos não tratados e HF150: animais leucêmicos tratados com HF $150 \mu \mathrm{g} / \mathrm{kg}$. Resultados representam a média e o desvio padrão de cada grupo.

\subsection{1 - Imunofenotipagem da medula óssea}

Com o objetivo de confirmar os achados da análise morfológica, suspensões celulares da medula óssea foram utilizadas para caracterização por meio de imunofenotipagem. Analisamos dentro da população celular $\mathrm{CD}^{4} 5^{+}$, que caracteriza leucócitos em diferentes estágios de maturação, as células que apresentam o fenótipo CD117 $7^{+} \mathrm{CD} 16 / 32^{+}$ correspondem as células leucêmicas e as células $\mathrm{CD}_{1} 1 \mathrm{~b}^{+} / \mathrm{Gr}-1^{+}$correspondem a células mielóides maduras. (Figura 10).

Os resultados ilustrados na Figura 11 indicam que, o grupo tratado com halofuginona apresentou em média um número menor de células $\mathrm{CD} 117^{+} / \mathrm{CD} 16 / 32^{+}$em relação aos animais não tratados $(16,88 \pm 6,27$ vs. 44,06 $\pm 27,06)$, porém essa quantidade de células imaturas não chegou à normalidade observada nos animais não transplantados $(3,36 \pm 1,06)$. Por outro lado, a porcentagem de células diferenciadas na medula óssea foi maior no grupo tratado em 
relação ao grupo controle não tratado, indicada pela presença de células $\mathrm{CD} 11 \mathrm{~b}^{+} / \mathrm{Gr}-1^{+}(75,8$ $\pm 7,55$ vs. $57,63 \pm 2,93, \mathrm{p}<0.0109)$.

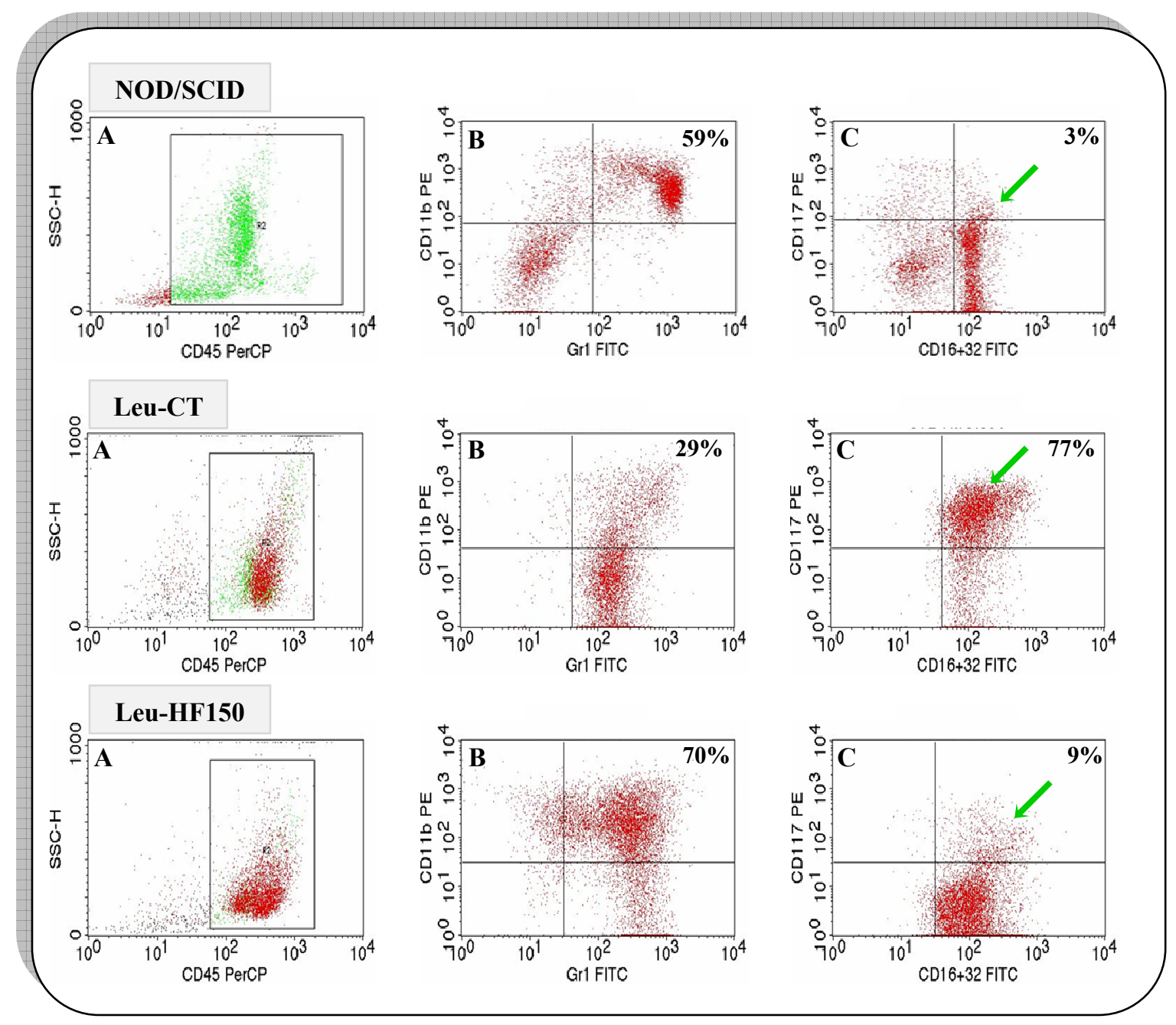

Figura 10 - Imunofenotipagem de células da medula óssea dos camundongos. As células primeiramente foram selecionadas de acordo com a marcação com anti-CD45-PerCP (Gráficos A). Os gráficos B ilustram a marcação com anticorpos anti-CD11b-PE e anti-Gr-1-FITC, caracterizando células mielóides diferenciadas; os gráficos $\mathrm{C}$ ilustram a marcação com os anticporpos anti-CD117-PE e anti-CD16/32-FITC, caracterizando as células mielóides imaturas (indicados pela seta verde). Os gráficos exemplificam o padrão observado em cada grupo: NOD/SCID, Leu-CT e Leu-HF150 


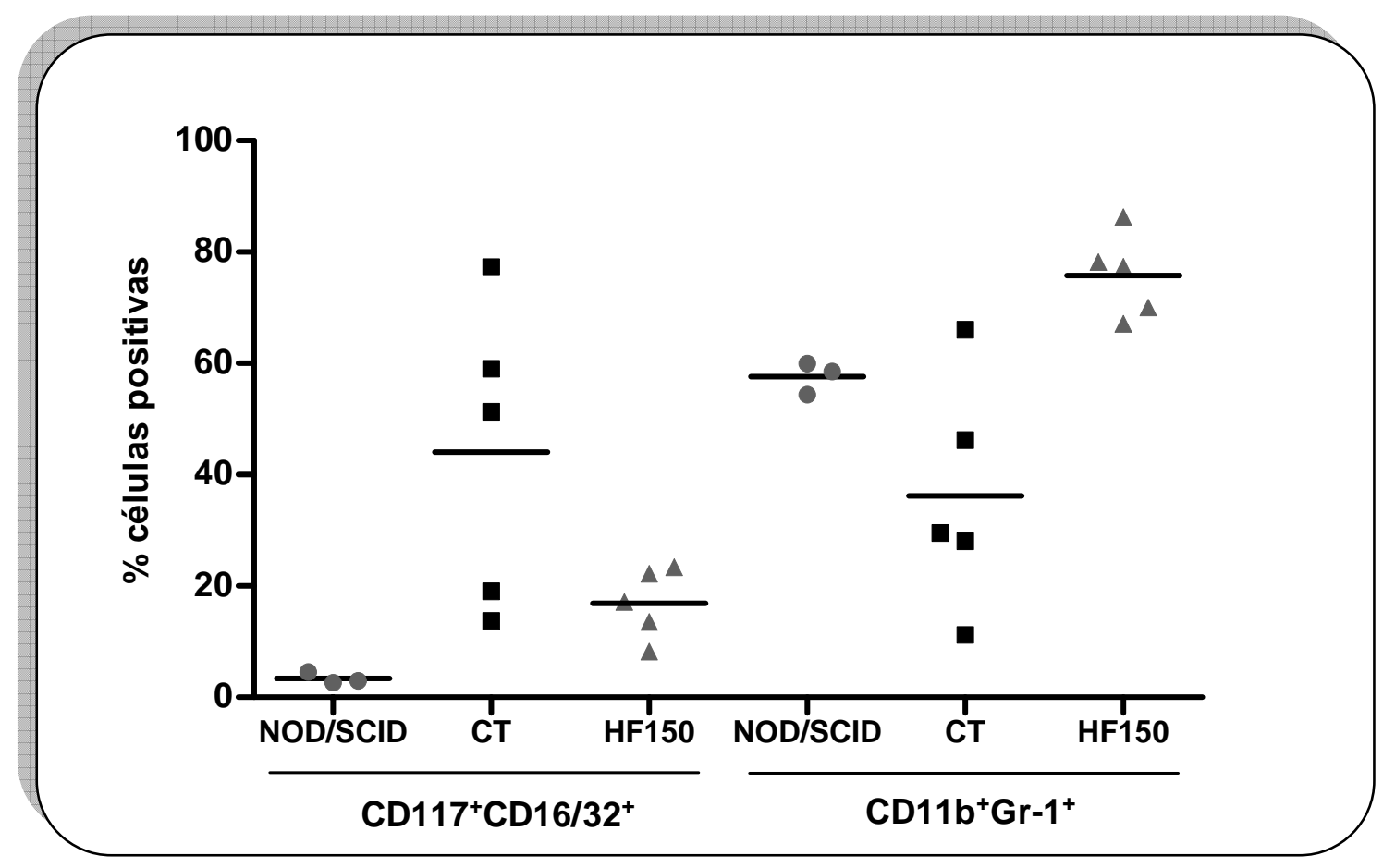

Figura 11 - Imunofenotipagem de células da medula óssea dos camundongos transplantados. O gráfico de barras indica a porcentagem de células imaturas $\left(\mathrm{CD} 117^{+} / \mathrm{CD} 16 / 32^{+}\right)$e de células diferenciadas $\left(\mathrm{CD} 11 \mathrm{~b}^{+} / \mathrm{Gr}^{-} 1^{+}\right)$encontradas na medula óssea de camundongos transplantados com células leucêmicas no $21^{\circ}$ dia de tratamento segundo os diferentes grupos: NOD/SCID: camundongo não leucêmico; CT: animais leucêmicos não tratados e HF150: animais leucêmicos tratados com HF $150 \mu \mathrm{g} / \mathrm{kg}$.

\section{5 - Avaliação da resposta molecular}

Células da medula óssea dos camundongos transplantados foram utilizadas para extração de DNA e posterior pesquisa da presença do gene $P M L-R A R \alpha$ por meio de reação de PCR. A Figura 12 mostra a presença do gene $P M L-R A R \alpha$ nos dois grupos estudados. Os animais foram analisados no final do período de tratamento (21 dias) e nenhuma diferença significativa foi encontrada, porém, é possível afirmar que houve enxertia das células leucêmicas em todos os animais transplantados. 


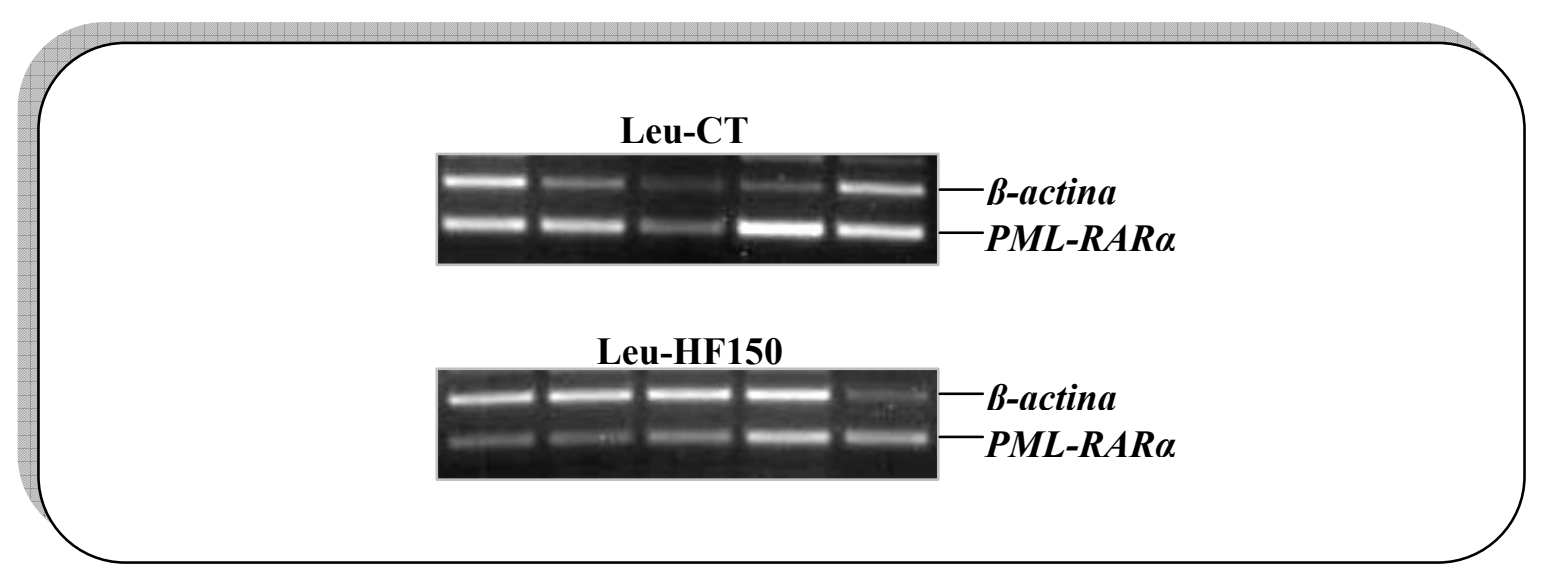

Figura 12 - Pesquisa do gene PML-RAR $\alpha$ por reação de PCR. Análise de células da medula óssea de camundongos transplantados; Leu-CT:grupo controle não tratado, Leu-HF150:grupo tratado com a dose de $150 \mu \mathrm{g} / \mathrm{kg}$ de halofuginona. O gene $\beta$-ACTINA foi utilizado como gene constitutivo para controle da amplificação. A figura indica os cinco animais de cada grupo estudado.

\section{6 - Análise da resposta clínica ao tratamento}

\subsection{1 - Avaliação do peso e infiltração do baço dos animais transplantados}

O peso do baço dos animais transplantados foi outro parâmetro analisado, uma vez que, a intensiva infiltração por células leucêmicas na LPA, leva ao aumento da massa deste órgão. Assim, todos os animais tiveram o peso do baço avaliado e este peso foi calculado em relação ao peso corporal Figura 13.

Corroborando com os resultados encontrados até o momento por meio da observação do sangue periférico e medula óssea, o baço dos animais transplantados que não receberam tratamento com halofuginona apresentaram peso superior em relação aos animais tratados. $\mathrm{O}$ tratamento com halofuginona resultou em redução a aproximadamente a metade do peso médio dos animais sem tratamento, embora a razão peso do baço/peso corporal tenha sido superior a mensurada nos camundongos NOD/SCID não transplantados. 


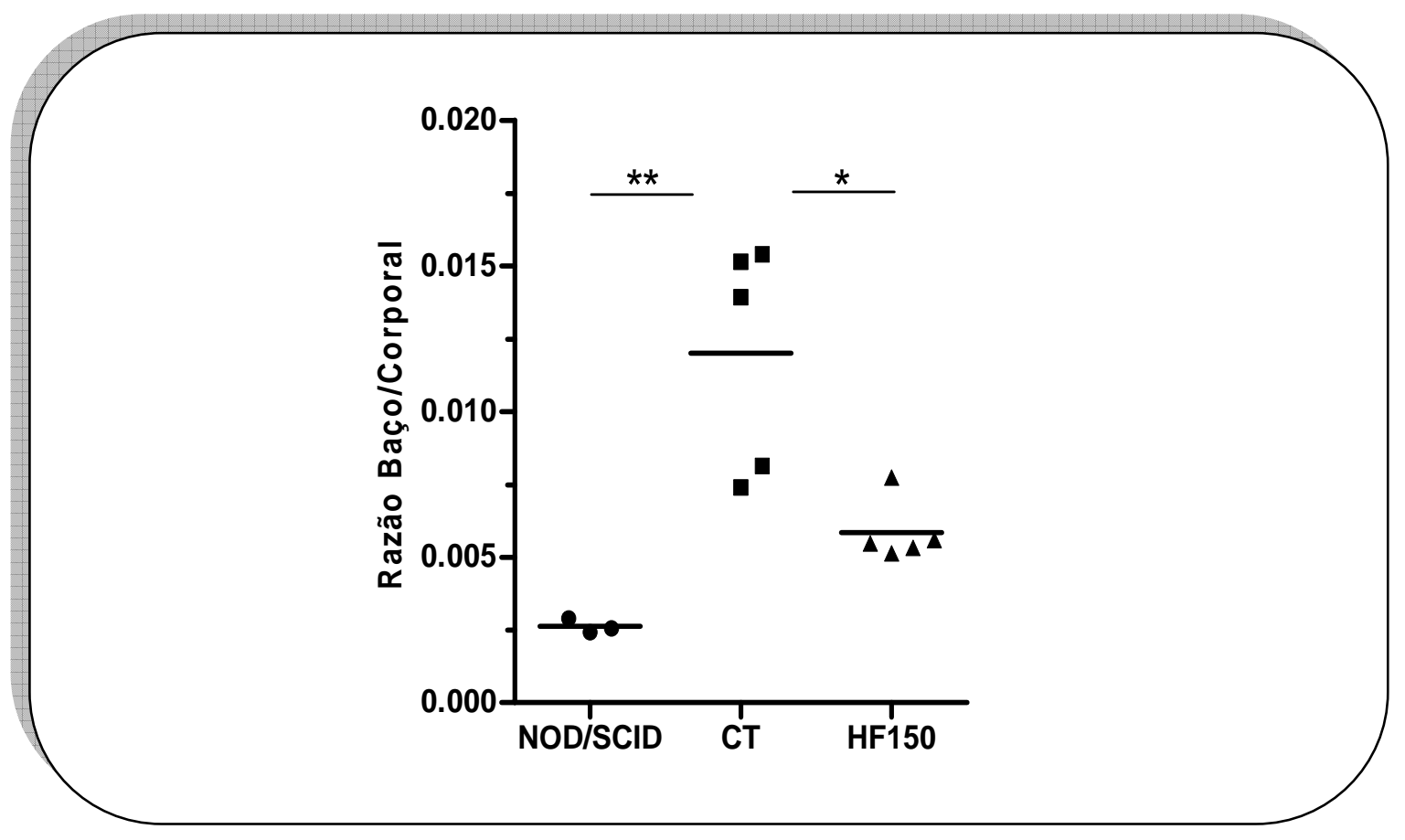

Figura 13 - Infiltração de células leucêmicas no baço dos animais transplantados. $O$ gráfico de pontos indica a relação peso baço/ peso corporal de cada animal nos diferentes grupos: NOD/SCID: camundongo não leucêmico, CT: leucêmico não tratado e HF150: leucêmico tratado com HF $150 \mu \mathrm{g} / \mathrm{kg}$.

A figura 14 exemplifica os achados morfológicos dos baços dos animais leucêmicos tratados ou não com halofuginona. Nos animais não tratados detectou-se infiltração por células leucêmicas (setas vermelhas) com características de promielócitos, (núcleo grande com cromatina frouxa, citoplasma basofílico com presença de grânulos azurófilos). Por outro lado, quando examinamos o baço dos animais tratados, notamos uma composição celular semelhante à normal, ou seja, presença de eritroblastos (seta laranja), células mielóides com maior grau de diferenciação (seta amarela), algumas células mielóides imaturas (seta vermelha) e células do tecido conjuntivo esplênico (seta branca). Esses achados sugerem que o tratamento com HF também diminuiu a proliferação de células leucêmicas nesse tecido. 

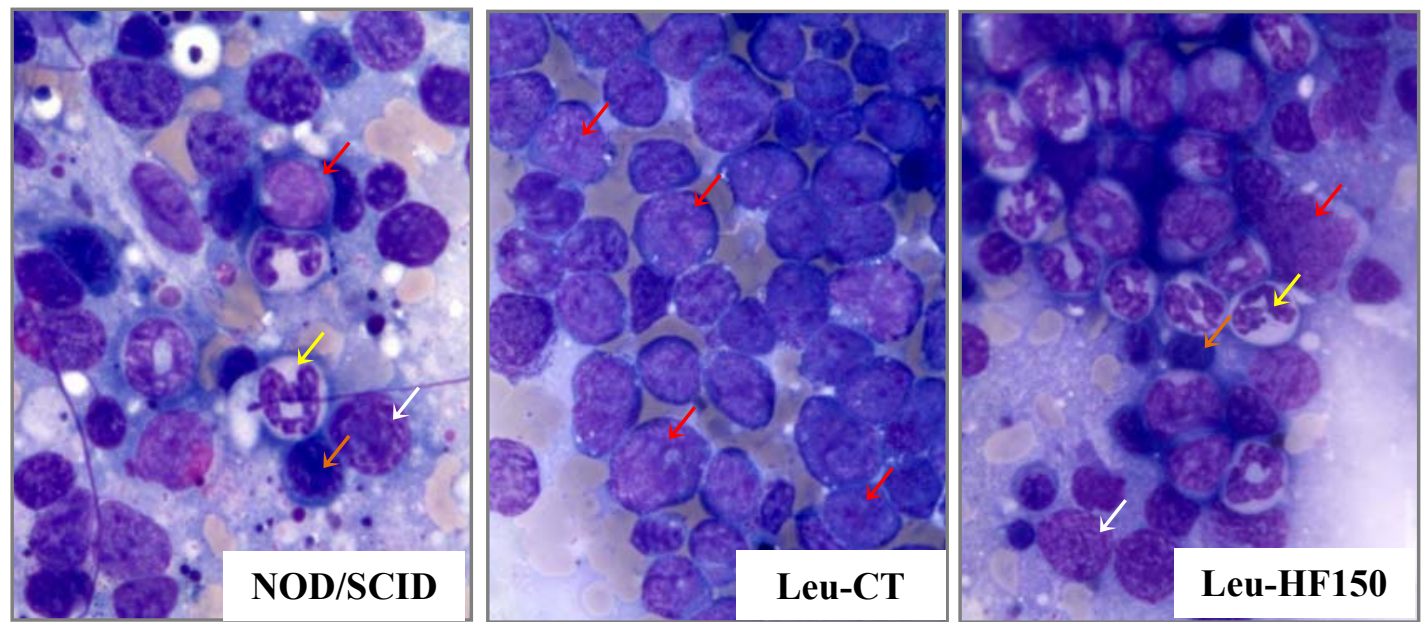

Figura 14 - Microfotografia de células do baço dos camundongos dos diferentes grupos. NOD/SCID: camundongo não leucêmico, CT: leucêmico não tratado e HF150: leucêmico tratado com HF $150 \mu \mathrm{g} / \mathrm{kg}$. As figuras mostram lâminas de imprint do baço coradas por Leishman. As setas amarelas indicam neutrófilos maduros, as vermelhas células vermelhas blastos leucêmicos e as laranjas eritroblastos. Aumento de 1000X.

\subsection{2 - Análise de Sobrevida}

A Figura 15 mostra que não houve diferença entre as curvas de sobrevida do grupo de animais não tratados e do grupo de animais que receberam HF. Em ambos os grupos as primeiras mortes ocorreram logo na primeira semana pós-transplante. O número e o intervalo até o óbito no decorrer do experimento também foi semelhante entre os dois grupos. Esse resultado indica que a HF não foi capaz de aumentar a sobrevida dos animais leucêmicos, independente das nossas observações mostrarem sua capacidade de inibir a progressão da doença pós- transplante. Sendo assim, a nossa hipótese foi de que as mortes estariam associadas a um possível efeito tóxico do tratamento neste modelo. 


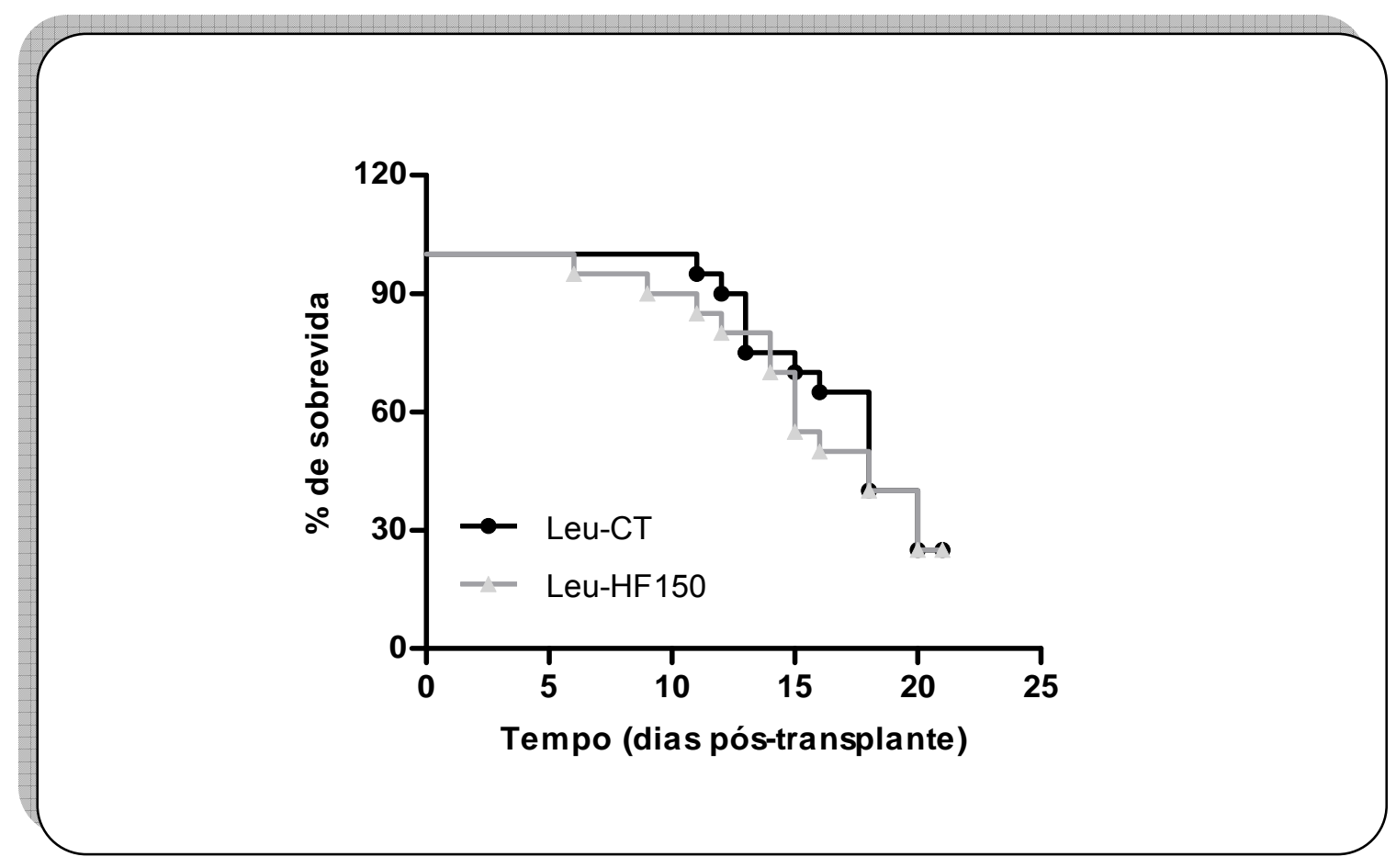

Figura 15 - Curva de tempo de sobrevida em dias dos camundongos receptores segundo os diferentes grupos de tratamento. A análise foi realizada pelo método de Kaplan-Meier.

\subsection{3 - Análise histomorfológica da toxicidade da halofuginona}

Para analisar mais detalhadamente a possível toxicidade gerada pela HF, fragmentos de baço, fígado, pulmão, coração, rim e cérebro foram obtidos após eutanásia dos camundongos dos diferentes grupos e encaminhados para o Laboratório de Patologia da Faculdade de Medicina de Ribeirão Preto. Esses tecidos foram incluídos em parafina e corados com hematoxilina e eosina para análise morfológica.

Por meio da analise histomorfológica, nenhum indício de toxicidade pode ser observado em qualquer amostra analisada. Esse estudo revelou que, tecidos como: pulmão, coração, rim e cérebro apresentaram estrutura preservada com morfologia e composição celular normal, sem indícios de infiltração por células leucêmicas (Figura 16). Por outro lado, 
órgãos como baço e fígado apresentaram grande quantidade de infiltração pode células neoplásicas.

Na Figura 17 podemos observar que o baço e o fígado encontravam-se extensivamente infiltrados por células leucêmicas. Em relação ao último, a análise histomorfológica mostrou infiltração infiltração difusa, incluindo espaços porta e sinusóides. Neste tecido ficou mais evidente a diferença entre os grupos, sendo o fígado do animal não tratado mais afetado do que àquele que recebeu HF.
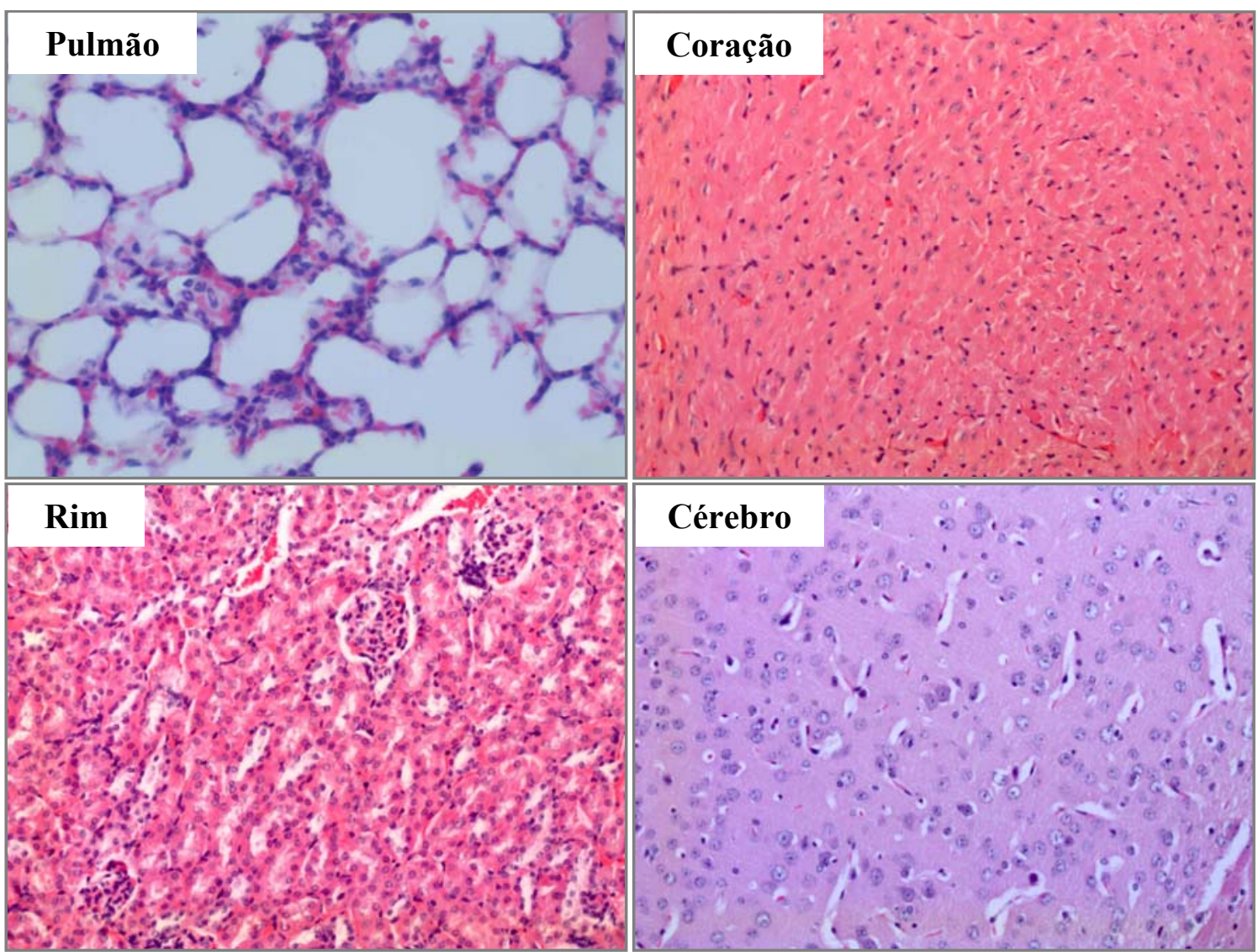

Figura 16 - Microfotografias de cortes de pulmão, coração, rim e cérebro dos camundongos leucêmcos utilizados para análise histomorfológica. Em cada figura está ilustrado um exemplo de cada tecido mostrando a constituição normal, sem infiltração por células leucêmicas ou indícios de alterações geradas por toxicidade ao tratamento com HF. Aumento de 200X. 

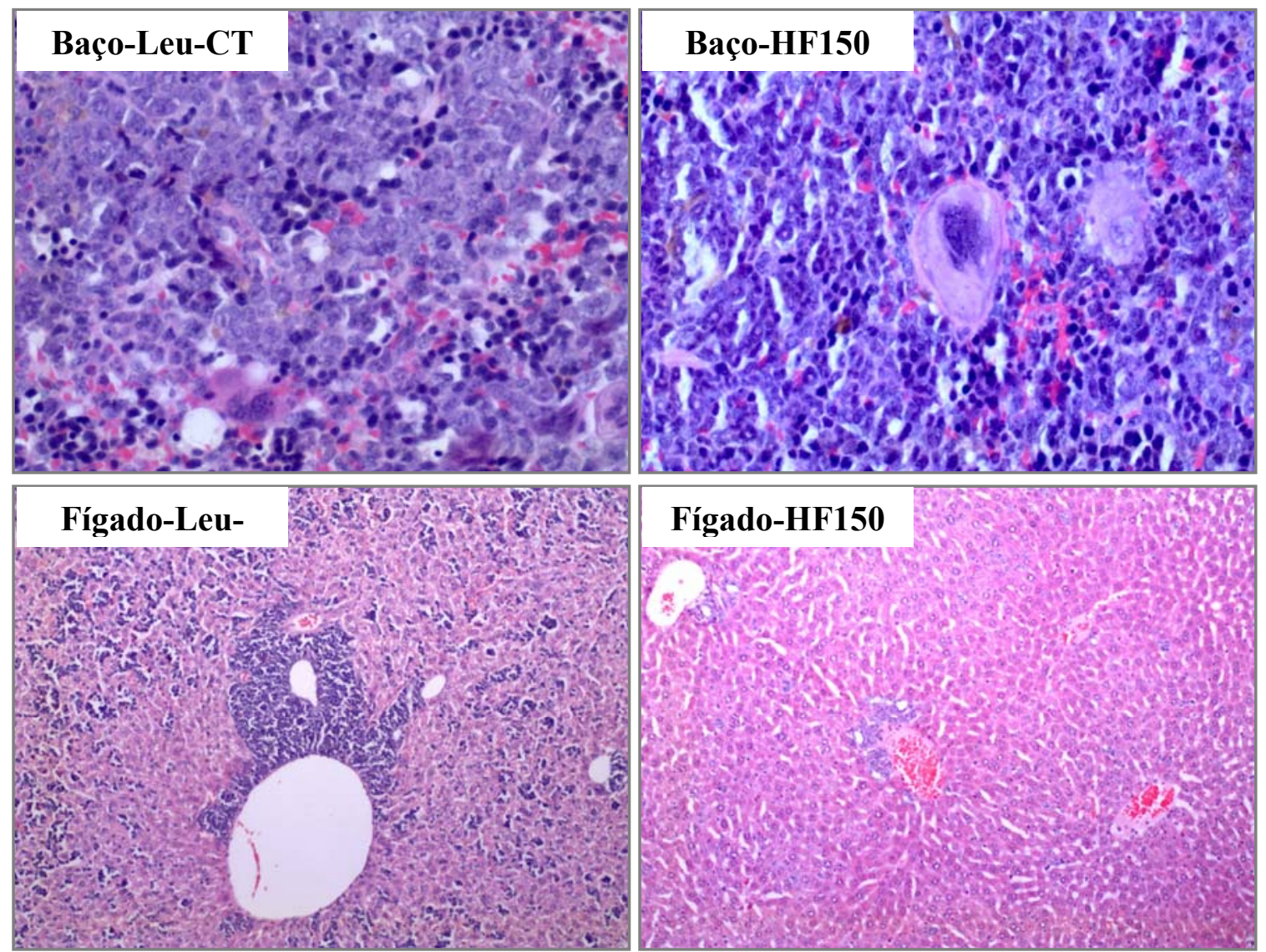

Figura 17 - Microfotografias de cortes de baço e fígado dos camundongos leucêmcos utilizados para análise histomorfológica. Em cada figura está ilustrado um exemplo de cada tecido de animais leucêmicos não tratados (Leu-CT) e tratados com HF (HF150). No baço e no fígado podemos observar a maior infiltração por células neoplásicas no grupo não tratado. Também não houve indícios de alterações geradas por toxicidade ao tratamento com HF. Aumento de $400 \mathrm{X}$ para o baço e $200 \mathrm{X}$ para o fígado.

\section{7 - Pesquisa de indicadores bioquímicos de toxicidade hepática e renal}

Para esclarecer essa questão sobre a possível toxicidade gerada pela HF, realizamos a dosagem dos níveis séricos de enzimas hepáticas e de creatinina. . Quatro diferentes grupos foram analisados, sendo: NOD/SCID: animais não transplantados como controles normais da linhagem; NOD/SCID+HF150: animais NOD/SCID não transplantados tratados com HF $150 \mu \mathrm{g} / \mathrm{kg}$; Leu-CT: animais leucêmicos não tratados e o grupo Leu+HF150: animais leucêmicos tratados com HF. A Figura 18 mostra que houve uma significativa elevação da enzima TGO/AST, nos grupos NOD/SCID+HF150 e Leu+ HF150 ( $p=0,0045)$ em 
comparação aos controles. Interessantemente, animais leucêmicos também apresentaram níveis aumentados dessa enzima em relação aos animais NOD/SCID (303.95 \pm 3.35 vs. 89.88 $\pm 11.65 ; \mathrm{p}=0,0002)$.

Com relação à enzima TGP/ALT, um perfil semelhante foi observado, no qual os animais leucêmicos apresentaram níveis mais elevados em relação aos NOD/SCID tratados ou não ( $p=0,0003)$. Já a enzima fosfatase alcalina e a creatinina não apresentaram níveis diferentes entre os grupos (Figura 18), esta última indicando que não houve dano renal causado pelo tratamento.

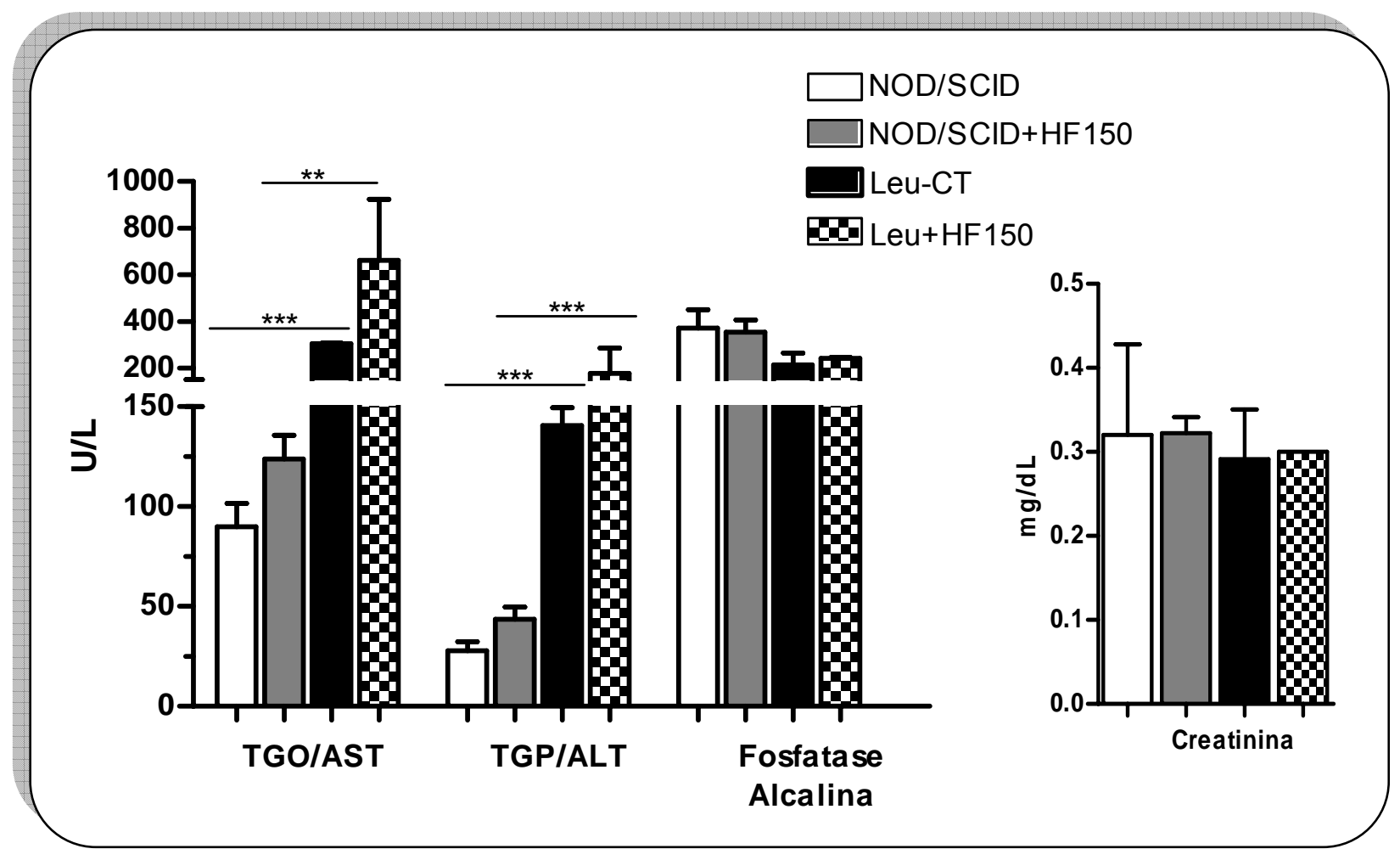

Figura 18 - Dosagem das enzimas TGO/AST, TGP/ALT e fosfatase alcalina e de creatinina. Amostras de soro foram obtidas dos diferentes grupos: NOD/SCID: animais não transplantados; NOD/SCID+HF 150: animais não transplantados tratados com HF $150 \mu \mathrm{g} / \mathrm{kg}$; Leu-CT: animais leucêmicos não tratados e o grupo Leu+HF150: animais leucêmicos tratados com HF. O gráfico indica a média de cada grupo \pm o desvio padrão. 


\section{8 - Expressão de genes envolvidos com a angiogênese e genes-alvo da via do TGF- $\beta$ por PCR em Tempo Real}

Os efeitos da halofuginona sobre a angiogênese e progressão tumoral também foram avaliados neste trabalho por meio da quantificação da expressão de genes envolvidos nas vias de angiogênese, como $V E G F$ e $E G F$ e de genes-alvo da via do TGF- $\beta$, como TGFB, SMAD3, SMAD4 e MYC. A análise dessa expressão foi realizada pelo método de PCR em tempo real a partir do RNA extraído de células da medula óssea dos camundongos tratados ou não com halofuginona $150 \mu \mathrm{g} / \mathrm{kg}$ (HF150). Amostras de camundongos NOD/SCID selvagens (WT) foram utilizadas como referência nesse estudo.

A Figura 19 mostra a expressão dos genes $V E G F$ e $E G F$. Podemos observar que entre os animais que não receberam tratamento dois apresentaram expressão do gene $V E G F$ aproximadamente duas vezes a expressão apresentada pelos animais selvagens, por outro lado entre os animais tratados com HF quatro apresentaram níveis de expressão semelhante à normalidade. Com relação ao $E G F$, quatro animais leucêmicos não tratados apresentaram expressão maior do que o grupo não leucêmico, sendo que em dois deles a expressão era maior do que o dobro, enquanto que no tratamento com halofuginona três animais apresentaram expressão menor do que os próprios níveis de normalidade.

Com relação aos genes-alvo da via do TGF- $\beta$, o primeiro gene estudado foi o próprio gene que codifica para a citocina TGF- $\beta$ e cuja expressão é regulada pela própria via por um mecanismo de feedback positivo 


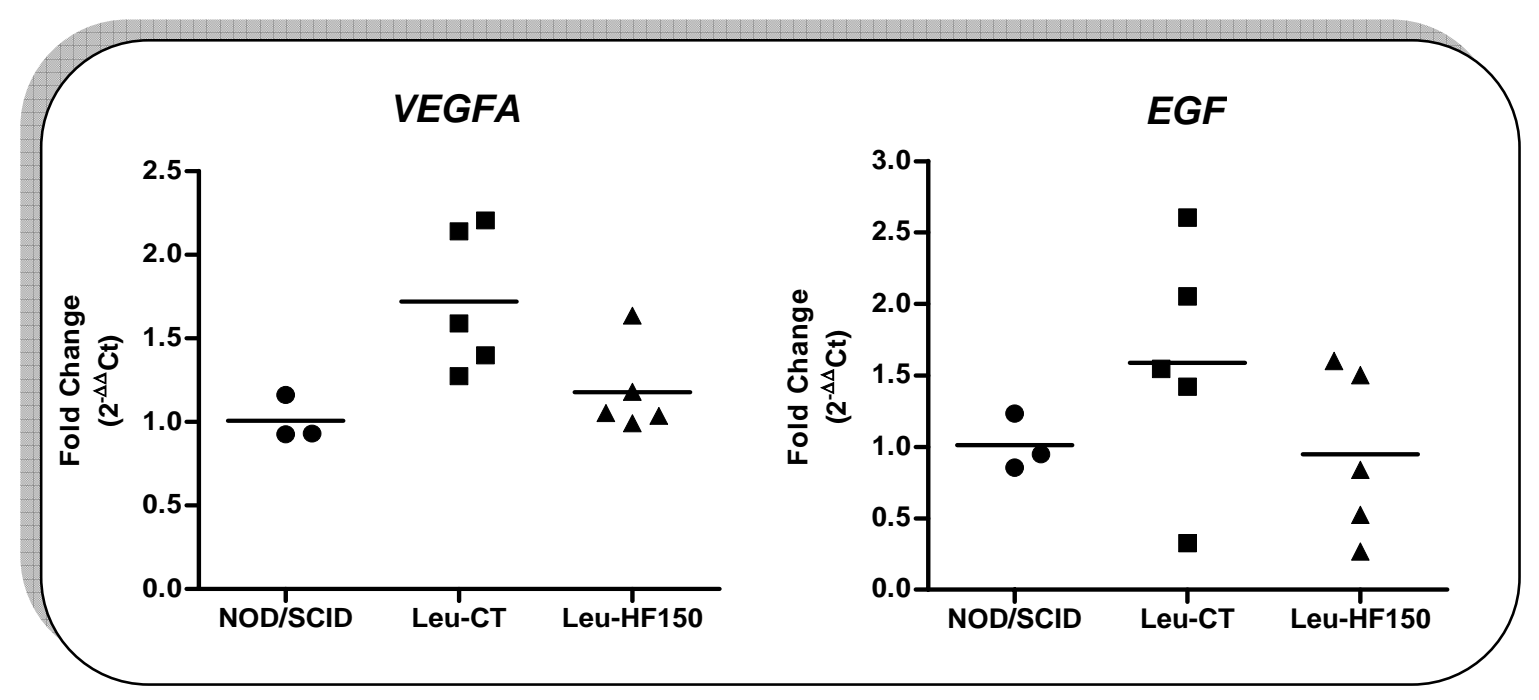

Figura 19- Expressão de genes envolvidos com angiogênese. Análise da expressão dos genes $V E G F$ e $E G F$, realizada por PCR em tempo real em células obtidas da medula óssea de camundongos NOD/SCID. No eixo Y estão indicados os valores de expressão. Após o transplante um grupo de animais foi injetado com solução salina (Leu-CT) e outro grupo com HF $150 \mu \mathrm{g} / \mathrm{kg}$ (Leu-HF150) durante 21 dias. No final deste período, os animais foram submetidos à eutanásia, células da medula óssea foram utilizadas para extração de RNA. Amostras de animais NOD/SCID não leucêmicos foram utilizadas como referência (Fold Change $=1,0)$.

Conforme ilustrado na Figura 20, a expressão deste gene em três dos animais leucêmicos não tratados mostrou ser no mínimo duas vezes a expressão observada nos animais não leucêmicos, já no grupo tratado com halofuginona, em média a expressão do $T G F B$ foi semelhante ao grupo não leucêmico. Assim, como o gene do TGF- $\beta$, os genes SMAD3 e SMAD4 são alvos desta via sendo também auto-regulados. Conforme ilustra a figura 20, a expressão de $S M A D 3$ foi menor nos grupos de animais leucêmicos, tratados ou não. Com relação ao $S M A D 4$, observamos que, a expressão deste gene foi semelhante entre os animais não doentes e os leucêmicos que não foram tratados, no entanto o tratamento com halofuginona resultou na diminuição da expressão deste gene em pelo menos a metade da expressão observada no grupo referência. Por fim, a expressão o gene $M Y C$ foi de pelo menos o dobro em relação ao animal não leucêmico em quatro dos cinco animais não tratados. $\mathrm{O}$ 
tratamento com halofuginona resultou em níveis de expressão de MYC semelhantes aos controles selvagens em quatro de cinco animais analisados.

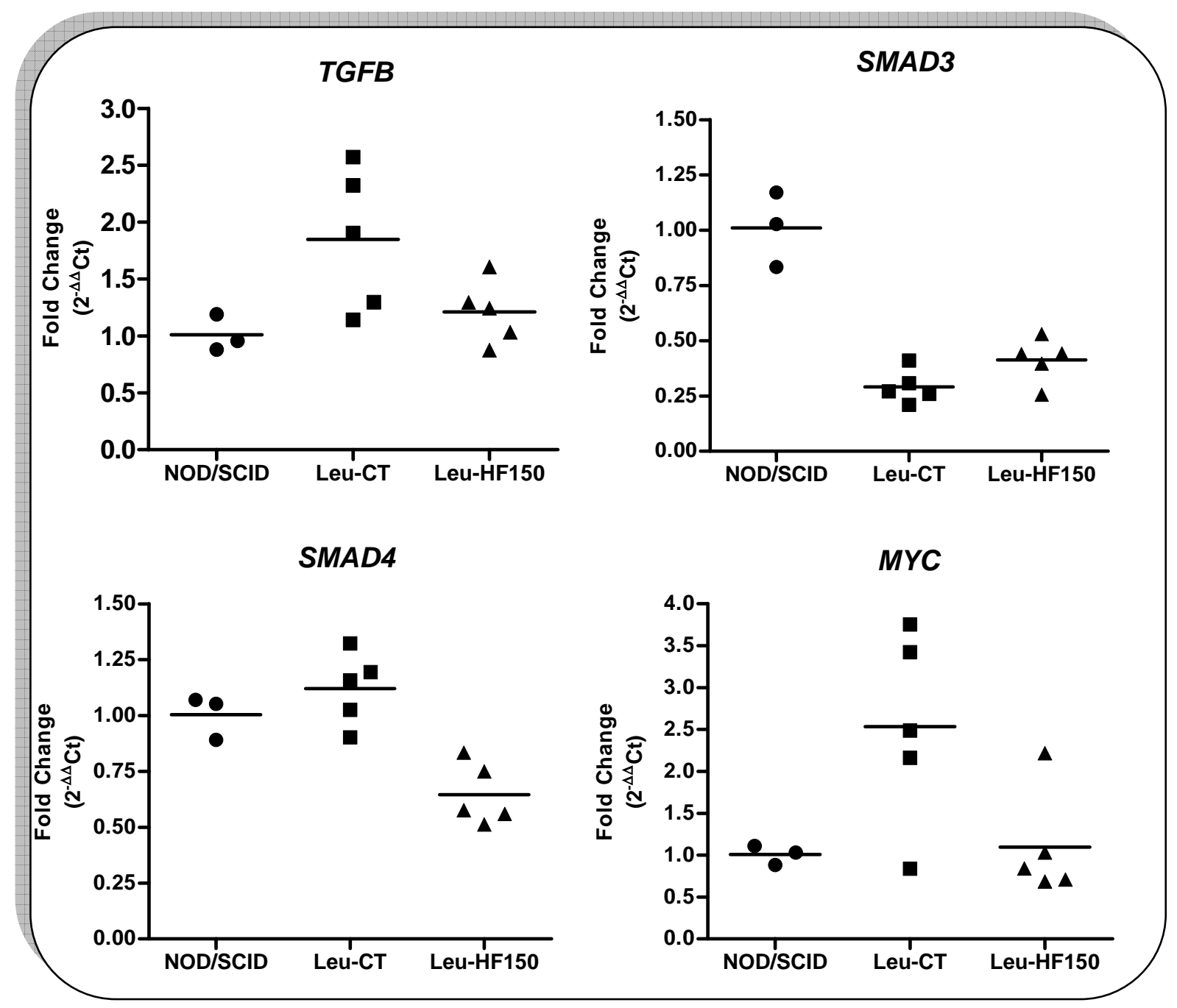

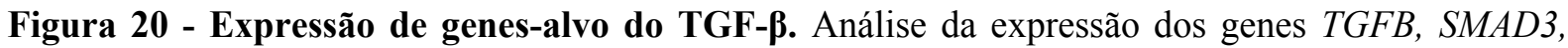
SMAD4 e MYC, realizada por PCR em tempo real em células obtidas da medula óssea de camundongos NOD/SCID. No eixo Y estão indicados os valores de expressão. Após o transplante um grupo de animais foi injetado com solução salina (Leu-CT) e outro grupo com HF $150 \mu \mathrm{g} / \mathrm{kg}$ (LeuHF150) durante 21 dias. No final deste período, os animais foram submetidos à eutanásia, células da medula óssea foram utilizadas para extração de RNA. Amostras de animais NOD/SCID não leucêmicos foram utilizadas como referência (Fold Change $=1,0)$. 


\section{9 - Quantificação da expressão de TGF- $\beta$ no soro e medula óssea dos camundongos leucêmicos por meio de ELISA}

A concentração do TGF- $\beta$ foi determinada em amostras de soro e no extrato protéico do lisado de células da medula óssea, após 21 dias de tratamento com HF ou salina nos animais transplantados. No gráfico da figura 21 observamos que os animais leucêmicos não tratados apresentaram menor nível de TGF- $\beta$ sérico em relação aos animais não leucêmicos e àqueles receberam HF. Este grupo tratado por sua vez apresentou níveis sérios elevados ( $\mathrm{p}<0,0001$ ), próximos ao normal. Por outro lado, quando analisamos o lisado de células da medula óssea notamos que os resultados não foram tão proeminentes, porém apresentaram a mesma tendência encontrada no soro.

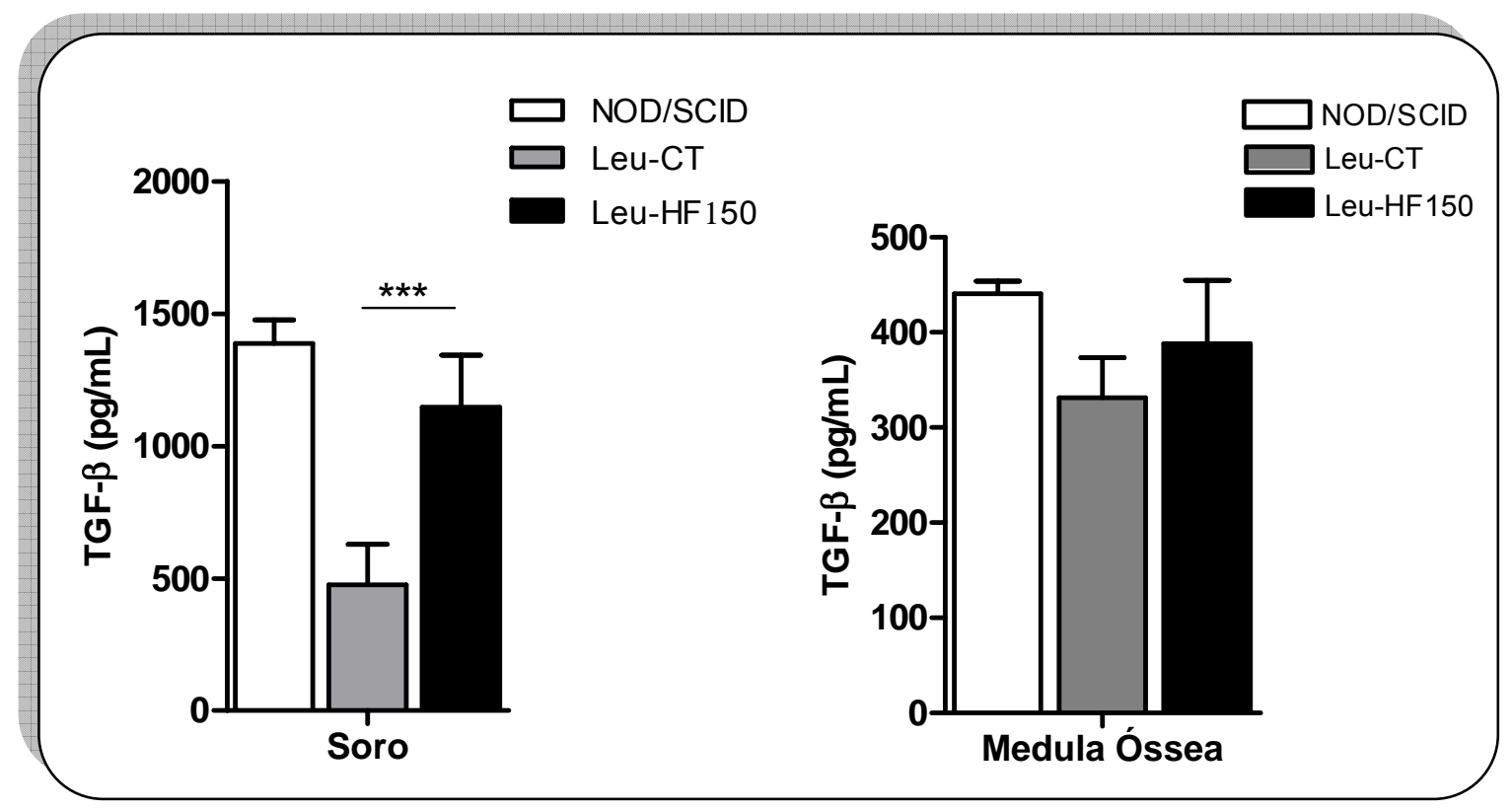

Figura 21 - Análise do efeito do tratamento com HF sobre a produção e secreção de TGF- $\beta$ em animais leucêmicos. Os gráficos indicam a concentração de TGF- $\beta(\mathrm{pg} / \mathrm{mL})$ no soro e no extrato protéico obtido de suspensões celulares da medula óssea nos diferentes grupos: NOD/SCID: não leucêmico, Leu-CT: leucêmico não tratado e Leu-HF150: leucêmico tratado com HF $150 \mu \mathrm{g} / \mathrm{kg}$. O resultado expressa a média de 5 animais de cada grupo, sendo o ensaio realizado em duplicata. 


\subsection{0 - Análise da expressão do VEGF e da DMV em biópsias de medula óssea dos camundongos leucêmicos}

Secções das vértebras dos animais dos diferentes grupos foram utilizadas para avaliar a expressão do fator VEGF na medula óssea, bem como a densidade microvascular (DMV), por meio de imunohistoquímica. A Tabela 4 e a Figura 22 mostram o resultado desses ensaios.

Tabela 4 - Análise qualitativa e quantitativa da expressão de VEGF e da densidade microvascular em amostras de medula óssea dos camundongos leucêmicos do grupo tratado (HF) ou não (CT) com halofuginona

\begin{tabular}{cccc}
\hline Grupo-Animal & $\begin{array}{c}\text { Intensidade da } \\
\text { expressão de VEGF }\end{array}$ & $\begin{array}{c}\text { Células positivas p/ } \\
\text { VEGF (\%) }\end{array}$ & DMV (vasos/mm $\left.\mathbf{m}^{\mathbf{2}}\right)$ \\
\hline CT-1 & +++ & 90 & 198 \\
CT-2 & +++ & 80 & 177 \\
CT-3 & +++ & 80 & 106 \\
CT-4 & +++ & 75 & 92 \\
CT-5 & +++ & 80 & 159 \\
HF-1 & + & 30 & 70 \\
HF-2 & ++ & 95 & 141 \\
HF-3 & - & $<10$ & 152 \\
HF-4 & - & $<10$ & 163 \\
HF-5 & + & 35 & 92 \\
\hline
\end{tabular}

A expressão de VEGF foi qualitativamente avaliando-se a intensidade de expressão como: negativa $(-)$, fraca $(+)$, moderada $(++)$ ou forte $(+++)$. Porcentagem de células positivas e número de vasos relativos à contagem de três campos de $400 \mathrm{X}$.

A expressão de VEGF foi analisada quantitativamente, determinando-se a porcentagem de células positivas em 1000 células medulares. Nas amostras de medula óssea de camundongos leucêmicos não tratados observamos maior expressão de VEGF em relação aos animais que receberam o tratamento. Na Figura 22 observamos que camundongos tratados apresentaram marcação para VEGF semelhante ao animal NOD/SCID não leucêmico. A 
DMV foi estudada por meio da contagem de número de microvasos $/ \mathrm{mm}^{2}$, identificados pela marcação com anticorpo anti-CD34. Os resultados mostraram que a despeito da maior expressão de VEGF no grupo CT, não houve diferença significativa entre os grupos com relação ao número de microvasos na medula óssea.
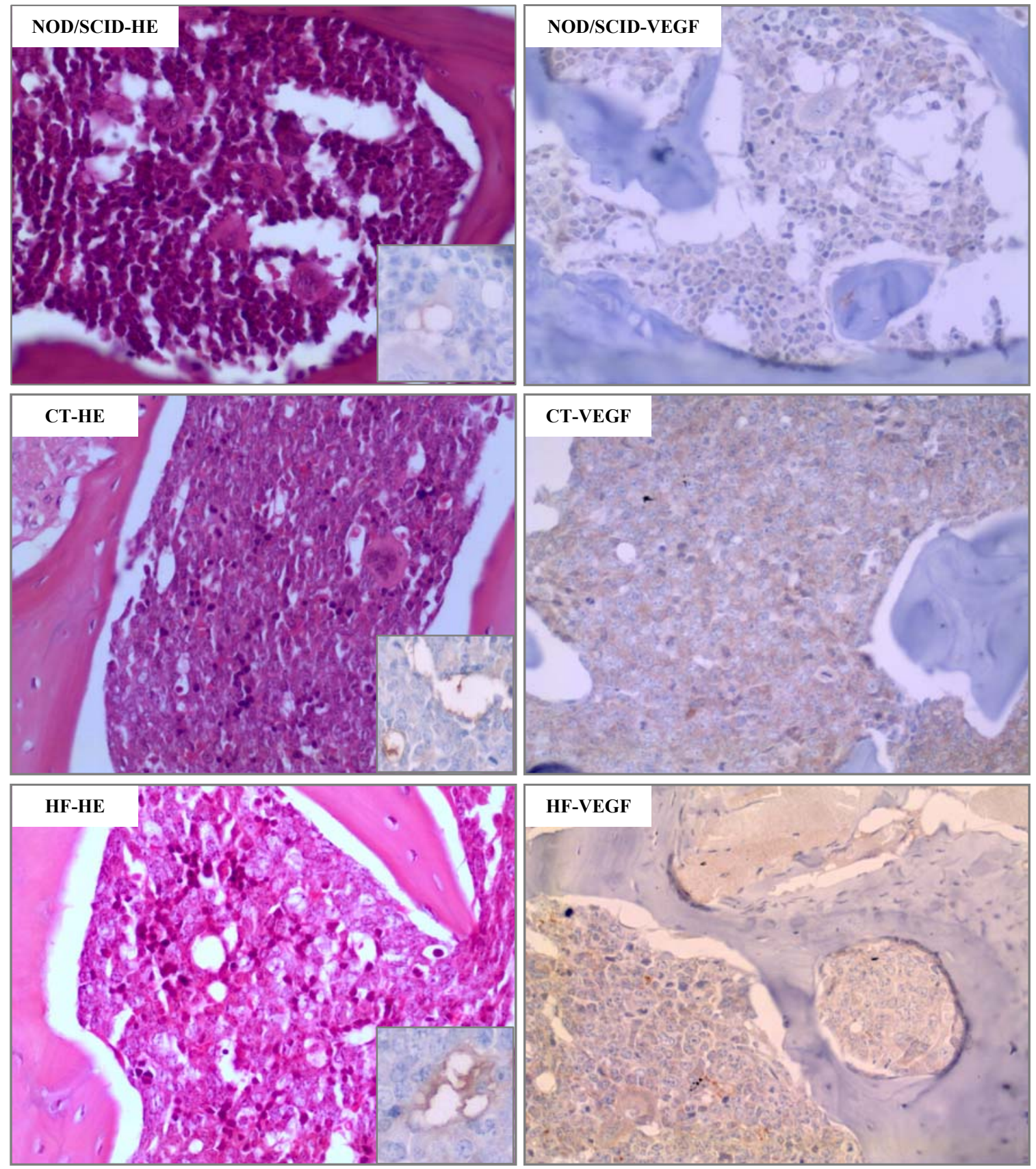

Figura 22 - Microfotografias de cortes da medula óssea dos camundongos NOD/SCID (contole negativo) e leucêmicos tratados (HF150) ou não (CT) com halofuginona. Análise histomorfológica (coloração com hematoxilina-eosina, HE) e imunohistoquímica com marcação para o VEGF. Os detalhes nas figuras de HE mostram a marcação de células endoteliais de microvasos com anti-CD34. Aumento de 400X. 
5-Díscussão 


\section{1 - A halofuginona exerce efeitos anti-proliferativos e pró-apoptóticos na LPA}

O primeiro estudo sobre o efeito da HF em linhagens celulares ou células primárias de leucemia promielocítica aguda foi realizado em nosso laboratório. (FIGUEIREDO-PONTES, Tese de Doutorado). Em ensaios com células NB4 e NB4-R2 houve inibição do crescimento celular e indução da apoptose de maneira dose-dependente. O estudo do ciclo celular, além de comprovar os efeitos anti-proliferativos, mostrou que a HF bloqueia a progressão do ciclo celular na fase G1/S. A ação da HF nas células NB4-R2, que são resistentes ao ATRA indicam que a ação da HF é independente da via retinóide (FIGUEIREDO-PONTES, Tese de Doutorado). No entanto, todos esses experimentos foram realizados após 24 horas de tratamento. Para complementar esses achados, analisamos a influência do tratamento com HF sobre a proliferação celular e apoptose em um momento mais precoce, 12 horas de tratamento, e em um momento mais tardio, após 48 horas. Assim como no trabalho realizado por Figueiredo-Pontes, observamos que a diminuição da proliferação celular pode estar associada ao bloqueio do ciclo celular na transição G1/S, e que esse efeito tem início já nas primeiras 12 horas de tratamento.

.Esses achados corroboram com o estudo em células de leiomioma no qual a HF induziu a apoptose e reduziu a síntese de DNA (GRUDZIEN et al., 2010). Gavish e colaboradores reportaram indução de apoptose pela HF em modelo de xenotransplante de câncer de próstata. Após dois meses de tratamento, os animais tratados com HF além de apresentarem menor crescimento do implante tumoral, também possuíam níveis séricos de PSA menores em relação aos controles não tratados (GAVISH et al., 2002).

Interessantemente, células de leiomioma e carcinoma hepatocelular tratadas com HF não apresentaram nenhum sinal de necrose ou perda de viabilidade, uma vez que a remoção do fármaco do meio de cultura restaura a capacidade da célula de proliferar (GRUDZIEN et 
al., 2010; NAGLER et al., 2004). O conjunto desses estudos reforçam o potencial antiproliferativo e pró-apoptótico da HF em diferentes tipos de tumores.

\section{2 - Halofuginona apresenta potencial antileucêmico em modelo in vivo de LPA}

No presente trabalho, nosso primeiro desafio foi elaborar um modelo in vivo de LPA e um protocolo de tratamento com halofuginona, no qual fosse possível avaliar os potenciais efeitos deste fármaco sobre a progressão da doença e a neovascularização na medula óssea. Com esse objetivo, optamos pelo modelo de transplante murino de células leucêmicas, devido à baixa penetrância e longa latência do modelo transgênico disponível (HE et al., 1997). Diferentes experimentos piloto foram realizados para determinar o melhor método de transplante das células hCG-PML-RAR $\alpha$, a latência entre o transplante e o desenvolvimento da doença, o período de tratamento, bem como a dose de halofuginona a ser utilizada. Para determinar as doses de tratamento, nos baseamos em diferentes trabalhos nos quais a halofuginona foi utilizada em modelos in vivo de tumores sólidos e fibrose (SHEFFER et al., 2007; TARAS et al., 2006; XAVIER et al., 2004; GAVISH et al., 2002; MCGAHA et al., 2002) bem como com estudos farmacocinéticos realizados com esta substância (STECKLAIR et al., 2001).

Os resultados obtidos nos experimentos iniciais nos conduziram a optar por um modelo de transplante no qual uma dose subletal de irradiação por $\mathrm{Co}^{60}$ (250 cGy) foi utilizada. Os animais começaram a receber halofuginona, por via intraperitonial, vinte e quatro horas após o transplante. Esta escolha baseou-se no fato de que o período entre as primeiras alterações do sangue periférico resultantes da infiltração leucêmica da medula óssea e o óbito dos animais foi muito curto, o que nos impossibilitou de avaliar a capacidade da halofuginona em inibir esse processo e/ou a neovasculogênese. 
A análise do hemograma dos animais evidenciou claramente que o grupo de animais leucêmicos não tratados apresentou leucocitose, associada com anemia e plaquetopenia, o que corresponde ao descrito no modelo transgênico (LEE et al., 1997). Por outro lado, os animais que após o transplante receberam tratamento com HF apresentaram número de leucócitos associado aos índices de hemoglobina e plaquetas próximos à normalidade, sugerindo que o tratamento induziu resposta hematológica.

Corroborando com esses resultados, a análise morfológica e imunofenotípica da medula óssea desses animais demonstrou redução significativa da infiltração leucêmica. Como esperado, os animais NOD/SCID não transplantados apresentaram menos de $5 \%$ de células mielóides imaturas, as quais caracterizam-se pela expressão concomitante de CD117 e CD16/32 (GUIBAL et al., 2009). Os animais leucêmicos, por sua vez, apresentaram elevada porcentagem dessas células imaturas $(\sim 50 \%)$ associada ao baixo número de células mais diferenciadas $(\sim 30 \%)\left(\mathrm{CD}_{11} \mathrm{~b}^{+} / \mathrm{Gr}-1^{+}\right)$. Na medula óssea dos animais tratados após o transplante podemos notar a presença muito maior de células diferenciadas $(\sim 60 \%)$ em relação às células mais imaturas $(\sim 25 \%)$. Esses resultados evidenciam o possível efeito da HF sobre o desenvolvimento da leucemia neste modelo de transplante murino.

A razão do peso do baço em relação ao peso corporal foi outro parâmetro analisado para caracterizar a infiltração leucêmica em modelos murinos de LPA. Como já descrito na literatura (HE et al., 1997), células neoplásicas hematopoiéticas infiltram extensivamente no baço de camundongos. A comparação deste parâmetro entre o grupo de camundongos leucêmicos não tratados e o grupo tratado com HF mostra uma clara diferença. O grupo tratado apresentou valores correspondentes a aproximadamente a metade do obtido no grupo leucêmico. Essa medida de infiltração leucêmica apoia os resultados encontrados até o momento sobre o potencial antileucêmico da HF neste modelo. 
A pesquisa de remissão molecular, por meio da amplificação do gene $P M L-R A R A$ não apontou diferenças entre os grupos tratados ou não. Este dado, por outro lado, indica que o transplante foi efetivo e que ambos os grupos possuíam o gene responsável por desencadear a LPA. Ademais, a curva de sobrevida mostrou que não houve diferenças entre os animais leucêmicos tratados ou não. Resultado semelhante foi apresentado por Taras e colaboradores, no qual ratos com carcinoma hepatocelular tratados com HF, apresentaram pouca melhora com relação à massa tumoral o que refletiu em porcentagem de sobrevida semelhante ao grupo não tratado, porém o tratamento resultou em significativa diminuição no número de metástases (TARAS et al., 2006). Concluímos que no modelo de LPA apresentado nesse trabalho, apesar de a halofuginona não ter induzido a completa remissão da doença, ela reduziu de forma significativa a infiltração de células leucêmicas, e podemos supor que a elevada mortalidade no grupo tratado estava associada a hepatotoxicidade da HF.

Um estudo farmacocinético foi realizado por Stecklair e colaboradores, no qual camundongos $\mathrm{CD}_{2} \mathrm{~F}_{1}$ apresentaram toxicidade apenas a doses de $\mathrm{HF}$ superiores a $1,5 \mathrm{mg} / \mathrm{kg}$ por via i.p (STECKLAIR et al., 2001). Sendo assim, restava compreender como a dose de 150 $\mu \mathrm{g} / \mathrm{kg}$ utilizada neste trabalho poderia ser tóxica. Para elucidar essa questão, realizamos a análise histomorfológica e a dosagem de enzimas como TGO/AST, TGP/ALT e fosfatase alcalina, utilizadas como indicadores de função hepática e para avaliar a atividade renal a creatinina foi dosada. A análise histomorfológica não revelou alterações celulares compatíveis com toxicidade em nenhum dos tecidos estudados, mas o baço e o fígado apresentavam-se extensivamente infiltrados por células neoplásicas. Interessantemente, observamos na dosagem de enzimas que animais NOD/SCID não leucêmicos tratados com HF não apresentaram aumento considerável desses marcadores, por outro lado, no animal leucêmico não tratado notamos um grande aumento na produção das enzimas TGO e TGP em relação ao animal não doente, e por fim, o tratamento com HF em animais leucêmicos elevou ainda mais 
o nível desses marcadores. Esses resultados em conjunto sugerem que a própria leucemia pode alterar a função hepática em camundongos devido à grande infiltração de células leucêmicas nesse órgão, levando desta forma, ao aumento da sensibilidade à HF neste modelo de doença.

\section{3 - A HF interfere com a via do TGF- $\beta$}

A ativação da via do TGF- $\beta$ é dependente da associação da proteína PML citoplasmática com as proteínas SARA e SMAD2/3. Lin e colaboradores, a partir das observações da importância da cPML nesta via, sugeriram que na LPA a proteína de fusão gerada PML-RAR $\alpha$ seqüestraria a cPML e consequentemente inibiria a via do TGF- $\beta$, causando a desregulação do ciclo celular e favorecendo a sobrevivência da célula leucêmica (LIN et al., 2004). Para testarmos esta hipótese, estudamos os níveis de fosforilação da proteîna SMAD2, quantificamos a expressão gênica e proteíca do TGF- $\beta$ e a expressão de genes alvo desta via.

Nossos resultados mostraram claramente que a HF inibiu a fosforilação da SMAD2 de forma dose-dependente e este efeito foi perceptível com apenas 6 horas de tratamento. Esses resultados estão em acordo com diferentes estudos que demonstraram a inibição da via do TGF- $\beta$ pela HF (GNAINSKY et al., 2007; LEIBA et al., 2006; XAVIER et al., 2004). Ademais, o grupo de McGaha demonstrou por Western Blotting que a HF inibiu a fosforilação do mediador SMAD3 e consequentemente a via que segue este fenômeno (MCGAHA et al., 2002).

A análise da expressão gênica revelou que animais leucêmicos apresentavam na medula óssea uma expressão aumentada de $T G F B$ em relação ao animal não doente. De fato, os animais leucêmicos que foram tratados com HF apresentaram expressão diminuída do 
mesmo gene. Esse resultado pode ser interpretado de duas formas: 1) o tratamento com HF levou à diminuição da transcrição de $T G F B$; ou 2) a maior expressão de $T G F B$ foi oriunda de células neoplásicas que infiltraram extensivamente a medula óssea dos animais leucêmicos, e uma vez que os animais tratados apresentavam menor número de células imaturas, consequentemente a expressão de $T G F B$ também foi menor. Interessantemente, a expressão de SMAD3 foi menor nos animais leucêmicos em relação aos animais não doentes, e o tratamento com HF pareceu não alterar esse padrão. Diferentemente, SMAD4 manteve sua expressão normal na leucemia, porém animais tratados com HF tiveram essa expressão diminuída.

Em outro experimento analisamos a secreção de TGF- $\beta$ no soro e na medula óssea. Surpreendentemente, os animais leucêmicos apresentaram níveis séricos desse fator menores do que os animais não doentes, enquanto que animais tratados com HF apresentaram níveis próximos ao normal. A análise da medula óssea não evidenciou a mesma diferença significativa, porém apresentou a mesma tendência (Figura 21). Em nossa hipótese, os camundongos leucêmicos apresentam menor secreção de TGF- $\beta$ devido à própria supressão da via nos blastos leucêmicos, por outro lado, como um mecanismo de "salvação", essas células passam a aumentar a expressão gênica na tentativa de reverter esse quadro. $O$ fato da via estar suprimida e o controle da expressão de SMAD3 e SMAD4 se dar por um mecanismo de retroalimentação positiva explicam por que não houve aumento na expressão desses genes em ambos os grupos.

A expressão do gene $M Y C$ foi analisada como um gene alvo da via do TGF- $\beta$. Além disto, o MYC tem sua expressão induzida pela oncoproteína PML-RAR $\alpha$ (CASINI \& PELICCI, 1999; YANG et al., 1999) e tem papel relevante na leucemogênese. Nossos resultados com o tratamento com HF são compatívéis com os dados de secreção de TGF- $\beta$. Uma vez que a expressão desse gene é inibida por meio da via do TGF- $\beta$ (CHEN; KANG; 
MASSAGUE, 2001) é perfeitamente plausível que nos animais tratados com HF em consequência da maior secreção deste fator, o gene $M Y C$ apresente sua expressão diminuída. Outra teoria poderia explicar o resultado observado. Como a HF diminui significativamente a infiltração leucêmica, a menor expressão de $M Y C$ no grupo tratado resulta da maior quantidade de células maduras, que sabidamente expressam menos $M Y C$.

\section{4 - A HF interfere com outras vias reguladoras da apoptose.}

Em continuidade a estes estudos, investigamos quais outras vias a HF poderia atuar e exercer seus efeitos pró-apoptóticos sobre as células NB4. Por meio da técnica de PCR array, identificamos principalmente a expressão de genes relacionados com a via de apoptose celular desencadeada pelos chamados receptores de "morte". A apoptose, ou morte celular programada, pode ser disparada por dois mecanismos distintos: a via intrínseca, que envolve disfunção mitocondrial, e uma via extrínseca, associada com a estimulação dos chamados receptores de morte (death receptors-DRs), localizados na membrana celular. Os DRs pertencem à superfamília de receptores do TNF e são capazes de induzir apoptose seletivamente em células tumorais (RUSSO et al., 2010). Os DRs FAS e TNFRSF10B, observados nesse estudo, e cuja expressão gênica mostrou-se aumentada, são alvos potenciais no tratamento de diferentes tipos de câncer. Os tratamentos convencionais como quimioterapias e radioterapia, ativam a via intrínseca de apototose, o que caracteriza pouca especificidade e elevada toxicidade, e por esse motivo, a busca por novos alvos terapêticos mais específicos ainda é objeto de grande interesse nas pesquisas.

O TNFRSF10B é o receptor do tipo 2 para uma família de proteínas chamada TRAIL (Tumor necrosis (TNF)-related apoptosis-inducing ligand). A característica mais importante destas moléculas é a grande sensibilidade das células tumorais a apoptose induzida por essa 
via, o que não ocorre com células não transformadas, sugerindo a importância dessas moléculas como alvos para terapias anti-câncer. A ligação de TRAIL em seus receptores leva ao recrutamento de caspases 8 e 10, seguida por subseqüente ativação das caspases efetoras 3 , 6 e 7 (TESTA 2010). Interessantemente, a análise de expressão gênica, realizada neste trabalho, mostrou nas células NB4 o aumento da expressão dos genes CASP8, CAPS10, CASP3, CASP6 e CASP7 após o tratamento com HF. Esses resultados sugerem que a HF pode induzir a apoptose nesta linhagem neoplásica por meio da ativação da via extrínseca de apoptose e que esta ativação pode ser tumor específica, uma vez que receptores da família TRAIL estão envolvidos.

\section{5 - HF reduz os níveis de moléculas pró-angiogênicas, mas não reduz a densidade microvascular}

Ao contrário do ocorrido com tumores sólidos, a correlação entre angiogênese e outros fatores prognósticos em LMAs foi pouco estudada até o momento. O estudo da angiogênese no modelo in vivo da LPA é inédito e reforça a hipótese de que as vias de sinalização que participam desse processo podem estar desreguladas e constituem potenciais alvos terapêuticos.

Os efeitos in vivo da HF em neoplasias hematopoéticas não foram estudados previamente. Na medida em que o papel da angiogênese nessas doenças começa a ser reconhecido, os estudos com uma substância potencialmente antiangiogênica são de grande valia. A HF é uma substância capaz de inibir de maneira abrangente a angiogênese, pois além de reduzir a expressão de mediadores envolvidos na neovascularização propriamente dita, é capaz de regular a via de sinalização do TGF- $\beta$. Assim, é plausível que este fármaco tenha potencial atividade antileucêmica. 
Conforme demonstramos nos experimentos in vitro, a HF de fato modula a ativação da via do TGF- $\beta$, por meio da inibição da fosforilação da proteína SMAD2 e SMAD3 (MCGAHA et al., 2002). Estudos recentes demonstraram que a relação do TGF- $\beta$ com angiogênese se dá por uma via associada aos receptores ALK1 e 5 e as SMADs1 e 5 (GOUMANS et al., 2009). Em contrapartida não há relatos na literatura sobre os efeitos da HF sobre essas vias, mas sim sobre sua capacidade de inibir a fosforilação das SMADs2 e 3 (MCGAHA et al., 2002).

A correlação entre a produção de fatores próangiogênicos e o aumento da DMV em pacientes com diferentes neoplasias hematológicas vem sendo cada vez mais reportada (SCHLIEMANN et al., 2006; LOGES, et al., 2005; HATFIELD et al., 2005; HUSSONG et al., 2000; LAI, et al., 2000; PADRO et al., 2000; AGUAYO et al., 1999). Ademais, animais transgênicos leucêmicos (hCG-PML-RAR $\alpha$ ) apresentaram na medula óssea maior DMV e expressão de VEGF do que os animais selvagens, sugerindo a importância da angiogênese como fator prognóstico da doença (FIGUEIREDO-PONTES, Tese de Doutorado). No mesmo trabalho, ensaios realizados com células de linhagem de LPA, NB4 e NB4-R2 demonstraram que o tratamento com HF foi capaz de diminuir a secreção de fatores próangiogênicos como VEGF e angiogenina.

No estudo in vivo dos efeitos antiangiogênicos da HF, no modelo proposto, observamos que animais leucêmicos apresentam maior expressão de fatores próangiogênicos na medula. Primeiramente na análise da expressão gênica, $V E G F$ e $E G F$ apresentaram expressão aumentada em relação aos animais não doentes. Como esperado, o grupo de animais leucêmicos tratados com HF apresentou menor expressão de ambos os genes. Corroborando com esses achados, a análise por imunohistoquímica revelou que os animais leucêmicos apresentavam maior expressão desse fator na medula óssea quando comparados com animais não doentes, e que o tratamento com HF reduziu essa expressão. 
A despeito dos resultados acima citados, não encontramos diferenças na DMV entre os grupos estudados. Em modelo de histiocitoma maligno cerebral em ratos, a imunohistoquímica pela marcação com anti-FvW (fator de von Willebrand) mostrou que o tratamento com HF inibiu a neovasculogênese no tecido malígno (ABRAMOVICH et al., 2004). Elkin e colaboradores também demonstraram em modelo de angiogênese em implante na córnea de camundongos, que a angiogênese induzida por bFGF foi reduzida em animais tratados com HF (ELKIN et al., 2000). Por outro lado, em modelo de cicatrização após irradiação, a HF também não foi capaz de inibir a formação de novos vasos no tecido epitelial (NAGLER et al., 2007). Esses resultados podem sugerir, que a influência do tratamento com HF sobre a neovasculogênese pode ser variável em diferentes tecidos. Resultado semelhante foi observado em pacientes com LMA refratária. O tratamento com o anti-VEGF bevacizumab (Avastin, Genentech) resultou apenas em modesto benefício clínico, e apesar de diminuir a expressão celular de VEGF não mostrou atividade antileucêmica (ZAHIRAGIC et al., 2007).

Diferentes trabalhos reportaram a relação entre o VEGF e a proliferação e sobrevivência celular. VEGF pode estar envolvido no controle da expressão da proteína antiapoptótica BCL-2, promovendo maior sobrevida em células primárias de leucemia mielóide e na linhagem celular HL-60. Este mecanismo pode estar relacionado com a indução da expressão de Hsp90, responsável por proteger BCL-2 da degradação (DIAS et al., 2002). Esse estudo corrobora com nosso resultado em células NB4, no qual a HF inibiu a expressão de BCL-2, sugerindo uma relação entre a inibição de VEGF por esta substância e a sobrevivência das células. Em 2009, Li e colaboradores demonstraram que VEGF regula positivamente a expressão de survivina, e que sua inibição pode induzir apoptose celular em células de linhagem de LMA (LI et al., 2008). Em estudo mais recente também em linhagem de célula leucêmica, Maraldi e colaboradores relacionaram a ativação de receptores de VEGF 
com vias mediadas por Nox2 e Nox4 (NADPH oxidases), que por sua vez estão envolvidos na ativação de mecanismos de proliferação celular (MARALDI et al., 2010).

Portanto, acreditamos que os resultados demonstrados sobre a expressão e produção de VEGF são relevantes e sugerem o potencial da HF não só sobre a angiogênese, mas também sobre a proliferação de células leucêmicas. No entanto, nem todos os mecanismos pelos quais a HF exerce seus efeitos inibitórios sobre o VEGF foram esclarecidos. Nossos resultados, por sua vez, são um dos primeiros indícios de como esse fármaco pode ser efetivo no tratamento de neoplasias hematológicas por meio da modulação de VEGF e os diferentes mecanismos relacionados. Apesar de não observarmos diminuição da DMV pós-tratamento, consideramos que o tratamento com HF pode ser efetivo em leucemias associado a tratamentos padrão. Esse estudo foi pioneiro e trouxe luz a novos fatores envolvidos na progressão da leucemia e possíveis novos alvos terapêuticos. 
6-Conclusão 
O presente trabalho demonstrou que a halofuginona apresenta atividade antileucêmica no modelo experimental de Leucemia Promielocítica Aguda e que a indução de apoptose pela via extrínseca e a inibição da proliferação são os possíveis mecanismos envolvidos. Embora a redução da neovascularização não tenha sido observada no modelo proposto, o tratamento foi capaz de inibir a expressão do VEGF, sugerindo uma possível ação antiangiogênica da HF. Em resumo, os resultados apontam a HF como possível fármaco no tratamento de neoplasias. 
Referências Bíbliográfícas 
ABRAMOVITCH, R. et al. Halofuginone inhibits angiogenesis and growth in implanted metastatic rat brain tumor model--an MRI study. Neoplasia, v. 6, n. 5, p. 480-489, Sep-Oct. 2004.

ABRAMOVITCH, R. et al. Inhibition of neovascularization and tumor growth, and facilitation of wound repair, by halofuginone, an inhibitor of collagen type I synthesis. Neoplasia, v. 1, n. 4, p. 321-329, Oct. 1999.

ABREU E LIMA, R.S. Determinação do efeito antileucêmico do succinato de $\alpha$-tocoferol no tratamento da leucemia promielocítica aguda no modelo transgênico PML-RARa. 2008. 158 f. Tese (Doutorado em Clínica Médica) - Faculdade de Medicina, Universidade de São Paulo, Ribeirão Preto, 2008.

AGUAYO, A. et al. Cellular vascular endothelial growth factor is a predictor of outcome in patients with acute myeloid leukemia. Blood, v. 94, n. 11, p. 3717-3721, Dec 1. 1999.

AKAHANE M. et al. Vascular endothelial growth factor-D is a survival factor for human breast carcinoma cells. Int J Cancer, v. 118, n. 4, p. 841-849, Feb 15. 2006.

AYALA F. et al. Contribution of bone microenvironment to leukemogenesis and leukemia progression. Leukemia, v. 23, n. 12, p. 2233-2241, Dec. 2009.

BATRA V. et al. Bronchoalveolar lavage fluid concentrations of transforming growth factor (TGF)-beta1, TGF-beta2, interleukin (IL)-4 and IL-13 after segmental allergen challenge and their effects on alpha-smooth muscle actin and collagen III synthesis by primary human lung fibroblasts. Clin Exp Allergy, v. 34, n. 3, p. 437-444, Mar. 2004.

BENCHETRIT, S. et al. Halofuginone reduces the occurrence of renal fibrosis in $5 / 6$ nephrectomized rats. Isr Med Assoc J, v. 9, n. 1, p. 30-34, Jan. 2007.

BENNETT, J.M. et al. A variant form of hypergranular promyelocytic leukaemia (M3). Br J Haematol, v. 44, n. 1, p. 169-170, Jan. 1980.

BERGERS, G.; BENJAMIN, L.E. Tumorigenesis and the angiogenic switch. Nat Rev Cancer, v. 3, n. 6, p. 401-410, Jun. 2003.

BHATTI, S.S. et al. Prognostic value of bone marrow angiogenesis in multiple myeloma: use of light microscopy as well as computerized image analyzer in the assessment of microvessel density and total vascular area in multiple myeloma and its correlation with various clinical, histological, and laboratory parameters. Am J Hematol, v. 81, n. 9, p. 649-656, Sep. 2006. 
BRUCK, R. et al. Halofuginone to prevent and treat thioacetamide-induced liver fibrosis in rats. Hepatology, v. 33, n. 2, p. 379-386, Feb. 2001.

BRUNNING, R.D. Classification of acute leukemias. Semin Diagn Pathol, v. 20, n. 3, p. 142-153, Aug. 2003.

CAMPIONI, D. et al.; "In vitro" evaluation of bone marrow angiogenesis in myelodysplastic syndromes: a morphological and functional approach. Leuk Res, v. 28, n. 1, p. 9-17, Jan. 2004.

CARMELIET, P. VEGF as a key mediator of angiogenesis in cancer. Oncology, v. 69 Suppl 3, n. p. 4-10, 2005.

CARMELIET, P. et al. Abnormal blood vessel development and lethality in embryos lacking a single VEGF allele. Nature, v. 380, n. 6573, p. 435-439, Apr 4. 1996.

CASINI, T.; PELICCI, P.G. A function of p21 during promyelocytic leukemia cell differentiation independent of CDK inhibition and cell cycle arrest. Oncogene, v. 18, p. 32353243, May 1999.

CAVALLARO, U. CHRISTOFORI, G. Molecular mechanisms of tumor angiogenesis and tumor progression. J Neurooncol, v. 50, n. 1-2, p. 63-70, Oct-Nov. 2000.

CHEN, C.R.; KANG, Y.; MASSAGUE, J. Defective repression of c-myc in breast cancer cells: A loss at the core of the transforming growth factor beta growth arrest program. Proc.Natl.Acad.Sci.U.S.A, v. 98, p. 992-999, Jan. 2001.

CHEN, R.L. et al. [Dynamic analysis of expression of VEGF and its receptor-2 in mouse model with acute myeloid leukemia]. Zhongguo Shi Yan Xue Ye Xue Za Zhi, v. 17, n. 4, p. 852-856, Aug. 2009.

COHEN, T. et al. VEGF121, a vascular endothelial growth factor (VEGF) isoform lacking heparin binding ability, requires cell-surface heparan sulfates for efficient binding to the VEGF receptors of human melanoma cells. J Biol Chem, v. 270, n. 19, p. 11322-11326, May 12. 1995.

DIAS, S. et al. VEGF(165) promotes survival of leukemic cells by Hsp90-mediated induction of Bcl-2 expression and apoptosis inhibition. Blood, v. 99, p. 2532-2540, Apr. 2002.

DICKSON, M.C. et al. Defective haematopoiesis and vasculogenesis in transforming growth factor-beta 1 knock out mice. Development, v. 121, n. 6, p. 1845-1854, Jun.1995. 
DOR, Y. et al. Vascular endothelial growth factor and vascular adjustments to perturbations in oxygen homeostasis. Am J Physiol Cell Physiol, v. 280, n. 6, p. C1367-1374, Jun. 2001.

ELKIN, M. et al. Halofuginone: a potent inhibitor of critical steps in angiogenesis progression. FASEB J, v. 14, n. 15, p. 2477-2485, Dec. 2000.

ELKIN, M. et al. Inhibition of matrix metalloproteinase- 2 expression and bladder carcinoma metastasis by halofuginone. Clin Cancer Res, v. 5, n. 8, p. 1982-1988, Aug. 1999.

ENHOLM, B. et al. Comparison of VEGF, VEGF-B, VEGF-C and Ang-1 mRNA regulation by serum, growth factors, oncoproteins and hypoxia. Oncogene, v. 14, n. 20, p. 2475-2483, May 22. 1997.

FERRARA, N. et al. The biology of VEGF and its receptors. Nat Med, v. 9, n. 6, p. 669-676, Jun. 2003.

FERRARA, N. Role of vascular endothelial growth factor in physiologic and pathologic angiogenesis: therapeutic implications. Semin Oncol, v. 29, n. 6 Suppl 16, p. 10-14, Dec. 2002 .

FERRARA, N.; HENZEL, W.J. Pituitary follicular cells secrete a novel heparin-binding growth factor specific for vascular endothelial cells. Biochem Biophys Res Commun, v. 161, n. 2, p. 851-858, Jun 15. 1989.

FIGUEIREDO-PONTES, L.L. Modulação da via de sinalização do TGF $\beta$ e do VEGF pela oncoproteína PML-RAR $\alpha$. 2007. 235 f. Tese (Doutorado em Clínica Médica) - Faculdade de Medicina, Universidade de São Paulo, Ribeirão Preto, 2007.

FLANDERS, K.C. Smad3 as a mediator of the fibrotic response. Int J Exp Pathol, v. 85, n. 2, p. 47-64, Apr. 2004.

FOLKMAN, J. Angiogenesis in cancer, vascular, rheumatoid and other disease. Nat Med, v. 1, n. 1, p. 27-31, Jan. 1995.

FOLKMAN, J. et al. Isolation of a tumor factor responsible for angiogenesis. J Exp Med, v. 133, n. 2, p. 275-288, Feb 1. 1971.

FUHRMANN-BENZAKEIN, E. et al. Elevated levels of angiogenic cytokines in the plasma of cancer patients. Int J Cancer, v. 85, n. 1, p. 40-45, Jan 1. 2000. 
GANJOO, K. Antiangiogenesis: a new approach to the treatment of lymphoma. Leuk Lymphoma, v. 48, n. 3, p. 454-455, Mar. 2007.

GAVISH, Z. et al. Growth inhibition of prostate cancer xenografts by halofuginone. Prostate, v. 51, n. 2, p. 73-83, May 1. 2002.

GERBER, H.P. et al. Vascular endothelial growth factor induces expression of the antiapoptotic proteins Bcl-2 and A1 in vascular endothelial cells. J Biol Chem, v. 273, n. 21, p. 13313-13316, May 22. 1998.

GNAINSKY, Y. et al. Gene expression during chemically induced liver fibrosis: effect of halofuginone on TGF-beta signaling. Cell Tissue Res, v. 328, n. 1, p. 153-166, Apr. 2007.

GOUMANS, M.J. et al. TGF-beta signaling in vascular biology and dysfunction. Cell Res, v. 19, n. 1, p. 116-127, Jan. 2009.

GOUMANS, M.J. et al. Activin receptor-like kinase (ALK)1 is an antagonistic mediator of lateral TGFbeta/ALK5 signaling. Mol Cell, v. 12, n. 4, p. 817-828, Oct. 2003.

GRATZINGER, D. et al. Microvessel density and expression of vascular endothelial growth factor and its receptors in diffuse large B-cell lymphoma subtypes. Am J Pathol, v. 170, n. 4, p. 1362-1369, Apr. 2007.

GRIMWADE, D. et al. Characterization of acute promyelocytic leukemia cases lacking the classic t(15;17): results of the European Working Party. Groupe Francais de Cytogenetique Hematologique, Groupe de Francais d'Hematologie Cellulaire, UK Cancer Cytogenetics Group and BIOMED 1 European Community-Concerted Action "Molecular Cytogenetic Diagnosis in Haematological Malignancies". Blood, v. 96, n. 4, p. 1297-1308, Aug 15. 2000.

GROSS, D.J. et al. Treatment with halofuginone results in marked growth inhibition of a von Hippel-Lindau pheochromocytoma in vivo. Clin Cancer Res, v. 9, n. 10 Pt 1, p. 3788-3793, Sep 1. 2003.

GRUDZIEN, M.M. et al. The antifibrotic drug halofuginone inhibits proliferation and collagen production by human leiomyoma and myometrial smooth muscle cells. Fertil Steril, v. 93, n. 4, p. 1290-1298, Mar 1. 2010.

GUIBAL, F.C. et al. Identification of a myeloid committed progenitor as the cancer-initiating cell in acute promyelocytic leukemia. Blood, v. 114, n. 27, p. 5415-5425, Dec 24. 2009.

GUPTA, K.; ZHANG, J. Angiogenesis: a curse or cure? Postgrad Med J, v. 81, n. 954, p. 236-242, Apr. 2005. 
GUTIERREZ, N.C. et al. Gene expression profile reveals deregulation of genes with relevant functions in the different subclasses of acute myeloid leukemia. Leukemia, v. 19, n. 3, p. 402-409, Mar. 2005.

HANAHAN, D.; FOLKMAN, J. Patterns and emerging mechanisms of the angiogenic switch during tumorigenesis. Cell, v. 86, n. 3, p. 353-364, Aug 9. 1996.

HATFIELD, K.J. et al. Release of angiopoietin-1 by primary human acute myelogenous leukemia cells is associated with mutations of nucleophosmin, increased by bone marrow stromal cells and possibly antagonized by high systemic angiopoietin-2 levels. Leukemia, v. 22, n. 2, p. 287-293, Feb. 2008.

HATFIELD, K.J. et al. Antiangiogenic therapy in acute myelogenous leukemia: targeting of vascular endothelial growth factor and interleukin 8 as possible antileukemic strategies. Curr Cancer Drug Targets, v. 5, n. 4, p. 229-248, Jun. 2005.

HATZI, E. et al. N-myc oncogene overexpression down-regulates IL-6; evidence that IL-6 inhibits angiogenesis and suppresses neuroblastoma tumor growth. Oncogene, v. 21, n. 22, p. 3552-3561, May 16. 2002.

HE, L.Z. et al. Acute leukemia with promyelocytic features in PML/RARalpha transgenic mice. Proc Natl Acad Sci U S A, v. 94, n. 10, p. 5302-5307, May 13. 1997.

HELDIN, C.H., et al. TGF-beta signalling from cell membrane to nucleus through SMAD proteins. Nature, v. 390, n. 6659, p. 465-471, Dec 4. 1997.

HOLDERFIELD, M.T.; HUGHES, C.C. Crosstalk between vascular endothelial growth factor, notch, and transforming growth factor-beta in vascular morphogenesis. Circ Res, v. 102, n. 6, p. 637-652, Mar 28. 2008.

HUSSONG, J.W. et al. Evidence of increased angiogenesis in patients with acute myeloid leukemia. Blood, v. 95, n. 1, p. 309-313, Jan 1. 2000.

INDRACCOLO, S. et al. Dormant tumors awaken by a short-term angiogenic burst: the spike hypothesis. Cell Cycle, v. 5, n. 16, p. 1751-1755, Aug. 2006.

JORGENSEN, J.M. et al. Angiogenesis in non-Hodgkin's lymphoma: clinico-pathological correlations and prognostic significance in specific subtypes. Leuk Lymphoma, v. 48, n. 3, p. 584-595, Mar. 2007. 
KARKKAINEN, M.J. et al. Vascular endothelial growth factor C is required for sprouting of the first lymphatic vessels from embryonic veins. Nat Immunol, v. 5, n. 1, p. 74-80, Jan. 2004.

KEITH, T. et al. Regulation of angiogenesis in the bone marrow of myelodysplastic syndromes transforming to overt leukaemia. Br J Haematol, v. 137, n. 3, p. 206-215, May. 2007.

KERBEL, R.; FOLKMAN, J. Clinical translation of angiogenesis inhibitors. Nat Rev Cancer, v. 2, n. 10, p. 727-739, Oct. 2002.

KINI, A.R. et al. Angiogenesis in acute promyelocytic leukemia: induction by vascular endothelial growth factor and inhibition by all-trans retinoic acid. Blood, v. 97, n. 12, p. 39193924, Jun 15. 2001.

KORKOLOPOULOU, P. et al. Prognostic evaluation of the microvascular network in myelodysplastic syndromes. Leukemia, v. 15, n. 9, p. 1369-1376, Sep. 2001.

KRETZSCHMAR, M. et al. A mechanism of repression of TGFbeta/ Smad signaling by oncogenic Ras. Genes Dev, v. 13, n. 7, p. 804-816, Apr 1. 1999.

KUZU, I. et al. Bone marrow microvessel density (MVD) in adult acute myeloid leukemia (AML): therapy induced changes and effects on survival. Leuk Lymphoma, v. 45, n. 6, p. 1185-1190, Jun. 2004.

LAI, R. et al. Pathologic diagnosis of acute lymphocytic leukemia. Hematol Oncol Clin North Am, v. 14, n. 6, p. 1209-1235, Dec. 2000.

LANOTTE, M. et al. NB4, a maturation inducible cell line with $\mathrm{t}(15 ; 17)$ marker isolated from a human acute promyelocytic leukemia (M3). Blood, v. 77, n. 5, p. 1080-1086, Mar 1. 1991.

LARCHER, F. et al. VEGF/VPF overexpression in skin of transgenic mice induces angiogenesis, vascular hyperpermeability and accelerated tumor development. Oncogene, v. 17, n. 3, p. 303-311, Jul 23. 1998.

LEIBA, M. et al. Halofuginone inhibits NF-kappaB and p38 MAPK in activated T cells. J Leukoc Biol, v. 80, n. 2, p. 399-406, Aug. 2006.

LEUNG, D.W. et al. Vascular endothelial growth factor is a secreted angiogenic mitogen. Science, v. 246, n. 4935, p. 1306-1309, Dec. 1989. 
LI, Y.H. et al. Elevated expressions of survivin and VEGF protein are strong independent predictors of survival in advanced nasopharyngeal carcinoma. J. Transl. Med. v. 6, n.1, Jan. 2008

LIN, H.K. et al. Cytoplasmic PML function in TGF-beta signalling. Nature, v. 431, n. 7005, p. 205-211, Sep 9. 2004.

LITWIN, C. et al. Role of the microenvironment in promoting angiogenesis in acute myeloid leukemia. Am J Hematol, v. 70, n. 1, p. 22-30, May. 2002.

LOGES, S. et al. Analysis of concerted expression of angiogenic growth factors in acute myeloid leukemia: expression of angiopoietin-2 represents an independent prognostic factor for overall survival. J Clin Oncol, v. 23, n. 6, p. 1109-1117, Feb 20. 2005.

LUNDBERG, L.G. et al. Angiogenesis in relation to clinical stage, apoptosis and prognostic score in myelodysplastic syndromes. Leuk Res, v. 30, n. 3, p. 247-253, Mar. 2006.

MACCHIARINI, P. et al. Relation of neovascularisation to metastasis of non-small-cell lung cancer. Lancet, v. 340, n. 8812, p. 145-146, Jul. 1992.

MARALDI, T. et al. VEGF-induced ROS generation from NAD(P)H oxidases protects human leukemic cells from apoptosis. Int. J. Oncol. v. 36, n. 6, p. 1581-9, Jun. 2010

MATTHEWS, W. et al. A receptor tyrosine kinase specific to hematopoietic stem and progenitor cell-enriched populations. Cell, v. 65, n. 7, p. 1143-1152, Jun 28. 1991.

MAYANI, H. Composition and function of the hemopoietic microenvironment in human myeloid leukemia. Leukemia, v. 10, n. 6, p. 1041-1047, Jun. 1996.

MAZUR, G. et al. Angiogenesis measured by expression of CD34 antigen in lymph nodes of patients with non-Hodgkin's lymphoma. Folia Histochem Cytobiol, v. 42, n. 4, p. 241-243, 2004.

MCGAHA, T.L. et al. Halofuginone, an inhibitor of type-I collagen synthesis and skin sclerosis, blocks transforming-growth-factor-beta-mediated Smad3 activation in fibroblasts. $\mathbf{J}$ Invest Dermatol, v. 118, n. 3, p. 461-470, Mar. 2002.

MELNICK, A.; LICHT, J.D. Deconstructing a disease: RARalpha, its fusion partners, and their roles in the pathogenesis of acute promyelocytic leukemia. Blood, v. 93, n. 10, p. 31673215, May 15. 1999. 
MUINDI, J. et al. Continuous treatment with all-trans retinoic acid causes a progressive reduction in plasma drug concentrations: implications forrelapse and retinoid "resistance" in patients with acute promyelocytic leukemia. Blood, v.79, n.2, p. 299-302. 2001.

NAGLER, A. et al. Effect of halofuginone, a collagen alpha1(I) inhibitor, on wound healing in normal and irradiated skin: implication for hematopoietic stem cell transplantation. Acta Haematol., v. 118, n. 2, p. 77-83, Jul. 2007

NAGLER, A. et al. Suppression of hepatocellular carcinoma growth in mice by the alkaloid coccidiostat halofuginone. Eur J Cancer, v. 40, n. 9, p. 1397-1403, Jun. 2004.

NAGLER, A. et al. Reduction in pulmonary fibrosis in vivo by halofuginone. Am J Respir Crit Care Med, v. 154, n. 4 Pt 1, p. 1082-1086, Oct. 1996.

NASH, A.D. et al. The biology of vascular endothelial growth factor-B (VEGF-B). Pulm Pharmacol Ther, v. 19, n. 1, p. 61-69, 2006.

NEGAARD, H.F. et al. Increased bone marrow microvascular density in haematological malignancies is associated with differential regulation of angiogenic factors. Leukemia, v. 23, n. 1, p. 162-169, Jan. 2009.

NEUFELD, G. et al. Vascular endothelial growth factor (VEGF) and its receptors. FASEB J, v. 13, n. 1, p. 9-22, Jan. 1999.

PADRO, T. et al. Increased angiogenesis in the bone marrow of patients with acute myeloid leukemia. Blood, v. 95, n. 8, p. 2637-2644, Apr 15. 2000.

PANTSCHENKO, A.G. et al. In vitro demonstration of breast cancer tumor cell subpopulations based on interleukin-1/tumor necrosis factor induction of interleukin-8 expression. Oncol Rep, v. 10, n. 4, p. 1011-1017, Jul-Aug. 2003.

PEREZ, A. et al. PMLRAR homodimers: distinct DNA binding properties and heteromeric interactions with RXR. Embo J, v. 12, n. 8, p. 3171-3182, Aug. 1993.

PINES, M. et al. Halofuginone to treat fibrosis in chronic graft-versus-host disease and scleroderma. Biol Blood Marrow Transplant, v. 9, n. 7, p. 417-425, Jul. 2003.

PINES, M. et al. Reduction in dermal fibrosis in the tight-skin (Tsk) mouse after local application of halofuginone. Biochem Pharmacol, v. 62, n. 9, p. 1221-1227, Nov 1. 2001. 
PINES, M.; NAGLER, A. Halofuginone: a novel antifibrotic therapy. Gen Pharmacol, v. 30, n. 4, p. 445-450, Apr. 1998.

PINES, M. et al. Halofuginone, a specific inhibitor of collagen type I synthesis, prevents dimethylnitrosamine-induced liver cirrhosis. J Hepatol, v. 27, n. 2, p. 391-398, Aug. 1997.

PLATE, K.H. et al. Up-regulation of vascular endothelial growth factor and its cognate receptors in a rat glioma model of tumor angiogenesis. Cancer Res, v. 53, n. 23, p. 58225827, Dec 1. 1993.

REMY, I. et al. PKB/Akt modulates TGF-beta signalling through a direct interaction with Smad3. Nat Cell Biol, v. 6, n. 4, p. 358-365, Apr. 2004.

RIBATTI, D. et al. The history of the angiogenic switch concept. Leukemia, v. 21, n. 1, p. 44-52, Jan. 2007.

ROFFE, S. et al. Halofuginone inhibits Smad3 phosphorylation via the PI3K/Akt and MAPK/ERK pathways in muscle cells: effect on myotube fusion. Exp Cell Res, v. 316, n. 6, p. 1061-1069, Apr 1. 2010.

RUSSO, M. et al. Exploring death receptor pathways as selective targets in cancer therapy. Biochem Pharmacol, v. n. p. Mar 17. 2010.

SALVEN, P. et al. Vascular endothelial growth factors VEGF-B and VEGF-C are expressed in human tumors. Am J Pathol, v. 153, n. 1, p. 103-108, Jul. 1998.

SANCHEZ-ELSNER, T. et al. Synergistic cooperation between hypoxia and transforming growth factor-beta pathways on human vascular endothelial growth factor gene expression. $\mathbf{J}$ Biol Chem, v. 276, n. 42, p. 38527-38535, Oct 19. 2001.

SCHLIEMANN, C. et al. Expression of angiopoietins and their receptor Tie2 in the bone marrow of patients with acute myeloid leukemia. Haematologica, v. 91, n. 9, p. 1203-1211, Sep. 2006.

SCHMIERER, B.; HILL, C.S. TGFbeta-SMAD signal transduction: molecular specificity and functional flexibility. Nat Rev Mol Cell Biol, v. 8, n. 12, p. 970-982, Dec. 2007.

SEMENZA, G.L. Expression of hypoxia-inducible factor 1: mechanisms and consequences. Biochem Pharmacol, v. 59, n. 1, p. 47-53, Jan 1. 2000. 
SENGER, D.R. et al. Tumor cells secrete a vascular permeability factor that promotes accumulation of ascites fluid. Science, v. 219, n. 4587, p. 983-985, Feb 25. 1983.

SHALABY, F. et al. Failure of blood-island formation and vasculogenesis in Flk-1-deficient mice. Nature, v. 376, n. 6535, p. 62-66, Jul 6. 1995.

SHALITIN, N. et al. Expression of procollagen C-proteinase enhancer in cultured rat heart fibroblasts: evidence for co-regulation with type I collagen. J Cell Biochem, v. 90, n. 2, p. 397-407, Oct 1. 2003.

SHEFFER, Y. et al. Inhibition of fibroblast to myofibroblast transition by halofuginone contributes to the chemotherapy-mediated antitumoral effect. Mol Cancer Ther, v. 6, n. 2, p. 570-577, Feb. 2007.

SHI, Y.; MASSAGUE, J. Mechanisms of TGF-beta signaling from cell membrane to the nucleus. Cell, v. 113, n. 6, p. 685-700, Jun 13. 2003.

SHIBUYA, M. et al. Nucleotide sequence and expression of a novel human receptor-type tyrosine kinase gene (flt) closely related to the fms family. Oncogene, v. 5, n. 4, p. 519-524, Apr. 1990.

SPIRA, G. et al. Halofuginone, a collagen type I inhibitor improves liver regeneration in cirrhotic rats. J Hepatol, v. 37, n. 3, p. 331-339, Sep. 2002.

STECKLAIR, K.P. et al. Pharmacokinetics and tissue distribution of halofuginone (NSC 713205) in CD2F1 mice and Fischer 344 rats. Cancer Chemother Pharmacol, v. 48, n. 5, p. 375-382, Nov. 2001.

TANIGAWA, N. et al. Tumor angiogenesis and mode of metastasis in patients with colorectal cancer. Cancer Res, v. 57, n. 6, p. 1043-1046, Mar 15. 1997.

TARAS, D. et al. Halofuginone suppresses the lung metastasis of chemically induced hepatocellular carcinoma in rats through MMP inhibition. Neoplasia, v. 8, n. 4, p. 312-318, Apr. 2006.

TELLO-MONTOLIU, A. et al. Angiogenin: a review of the pathophysiology and potential clinical applications. J Thromb Haemost, v. 4, n. 9, p. 1864-1874, Sep. 2006.

TESTA, U. TRAIL/TRAIL-R in hematologic malignancies. J Cell Biochem, v. 110, n. 1, p. 21-34, May. 2010. 
VACCA, A. et al. Bone marrow neovascularization, plasma cell angiogenic potential, and matrix metalloproteinase-2 secretion parallel progression of human multiple myeloma. Blood, v. 93, n. 9, p. 3064-3073, May 1. 1999.

VACCA, A. et al. Bone marrow angiogenesis and progression in multiple myeloma. Br $\mathbf{J}$ Haematol, v. 87, n. 3, p. 503-508, Jul. 1994.

VAN DONGEN, J.J. et al. Standardized RT-PCR analysis of fusion gene transcripts from chromosome aberrations in acute leukemia for detection of minimal residual disease. Report of the BIOMED-1 Concerted Action: investigation of minimal residual disease in acute leukemia. Leukemia, v. 13, n. 12, p. 1901-1928, Dec. 1999.

VARDIMAN, J.W. et al. The 2008 revision of the World Health Organization (WHO) classification of myeloid neoplasms and acute leukemia: rationale and important changes. Blood, v. 115, n. 3, p. 748-749, Jan. 2010.

VERSTOVSEK, S. et al. Prognostic significance of cellular vascular endothelial growth factor expression in chronic phase chronic myeloid leukemia. Blood, v. 99, n. 6, p. 22652267, Mar 15. 2002.

VILLACORTA, I. et al. Efficacy of halofuginone lactate against Cryptosporidium parvum in calves. Antimicrob Agents Chemother, v. 35, n. 2, p. 283-287, Feb. 1991.

VITOUX, D.; NASR, R.; DE THÉ, H. Acute promyelocytic leukemia: new issues on pathogenesis and treatment response. Int J Biochem Cell BioL, n. 39, v. 6, p. 1063-70, Mar. 2007.

WANG, E.S. et al. Targeting autocrine and paracrine VEGF receptor pathways inhibits human lymphoma xenografts in vivo. Blood, v. 104, n. 9, p. 2893-2902, Nov 1. 2004.

WATARAI, M. et al. Expression of endothelial cell-associated molecules in AML cells. Leukemia, v. 16, n. 1, p. 112-119, Jan. 2002.

WEIDNER, N. et al. Tumor angiogenesis correlates with metastasis in invasive prostate carcinoma. Am J Pathol, v. 143, n. 2, p. 401-409, Aug. 1993.

WEIDNER, N. et al. Tumor angiogenesis and metastasis--correlation in invasive breast carcinoma. N Engl J Med, v. 324, n. 1, p. 1-8, Jan 3. 1991.

WELLMANN, S. et al.; Activation of the HIF pathway in childhood ALL, prognostic implications of VEGF. Leukemia, v. 18, n. 5, p. 926-933, May. 2004. 
WIMAZAL, F. et al. Idiopathic cytopenia of undetermined significance (ICUS) versus low risk MDS: the diagnostic interface. Leuk Res, v. 31, n. 11, p. 1461-1468, Nov. 2007.

XAVIER, S. et al. Amelioration of radiation-induced fibrosis: inhibition of transforming growth factor-beta signaling by halofuginone. J Biol Chem, v. 279, n. 15, p. 15167-15176, Apr 9. 2004.

YANG, X.; CEPKO, C.L. Flk-1, a receptor for vascular endothelial growth factor (VEGF), is expressed by retinal progenitor cells. J Neurosci, v. 16, n. 19, p. 6089-6099, Oct 1. 1996.

YANG, W.L. et al. Transcriptional activation of the cyclin-dependent kinase inhibitor p21 by PML/RARalpha. Mol.Cell Biol.Res.Commun., v. 1, p. 125-131, May. 1999.

ZAHIRAGIC,L. et al. Bevacizumab reduces VEGF expression in patients with relapsed and refractory acute myeloid leukemia without clinical antileukemic activity. Leukemia, v. 21, n. 6, p. 1310-2, Mar. 2007.

ZHANG, H. et al. Inhibition of both the autocrine and the paracrine growth of human leukemia with a fully human antibody directed against vascular endothelial growth factor receptor 2. Leuk Lymphoma, v. 45, n. 9, p. 1887-1897, Sep. 2004. 
Anexos 


\title{
ANEXO A - Parecer do Comitê de Ética em Pesquisa
}

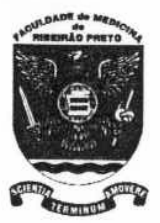

\author{
UNIVERSIDADE DE SÃO PAULO \\ FACULDADE DE MEDICINA DE RIBEIRÃO PRETO \\ — Comissão de Ética em Experimentação Animal -
}

\section{E R T I F I C A D O}

Certificamos que o Protocolo parà Uso de Animais em Experimentação $\mathrm{n}^{\circ} \mathbf{0 6 2} / \mathbf{2 0 0 8}$, sobre o projeto intitulado "Análise do efeito antileucêmico da halofuginona no modelo transgênico da leucemia promielocítica aguda", sob a responsabilidade do Professor Doutor Eduardo Magalhães Rego está de acordo com os Princípios Éticos na Experimentação Animal adotado pelo Colégio Brasileiro de Experimentação Animal (COBEA) e foi APROVADO pela COMISSÃO DE ÉTICA EM EXPERIMENTAÇÃO ANIMAL (CETEA) em reunião de 25 de agosto de 2008.

(We certify that the protocol $n^{\circ} 062 / 2008$, about "Analysis of the antileukemic effect of halofuginone in the transgenic model of acute promyelocytic leukemia", agrees with the ETHICAL PRINCIPLES IN ANIMAL RESEARCH adopted by Brazilian College of Animal Experimentation (COBEA) and was approved by the COLLEGE OF MEDICINE OF RIBEIRÅO PRETO OF THE UNIVERSITY OF SÃO PAULO - ETHICAL COMMISSION OF ETHICS IN ANIMAL RESEARCH (CETEA) in 08/25/2008 meeting).

Ribeirão Preto, 25 de agosto de 2008.

$$
\text { (oduendodin) a }
$$

Prof. Dr. Eduardo Melani Rocha Presidente da Comissão de Ética em Experimentação Animal 
ANEXO B - Genes analisados pelo kit RT $^{2}$ Profiler $^{\mathrm{TM}}$ PCR Array (SA Biosciences, Frederick, MD, USA). A média dos Cts obtidos foram utilizadas para cálculo do fold change $\left(2^{-\Delta \Delta C t}\right)$.

\begin{tabular}{|c|c|c|c|}
\hline \multirow[t]{2}{*}{ Genes } & \multicolumn{3}{|c|}{$2^{-\Delta \Delta C T}$} \\
\hline & CTRL & HF $50 \mathrm{ng} / \mathrm{mL}$ & HF $200 \mathrm{ng} / \mathrm{mL}$ \\
\hline ABL1 & 1 & 1.467738752 & 1.813090096 \\
\hline AKT1 & 1 & 0.714423866 & 0.83687257 \\
\hline APAF1 & 1 & 2.383194866 & 3.518187604 \\
\hline BAD & 1 & 1.079519548 & 1.468155111 \\
\hline BAG1 & 1 & 0.427063524 & 0.453146398 \\
\hline BAG3 & 1 & 0.236274813 & 0.667734149 \\
\hline BAG4 & 1 & 1.191429667 & 1.965694621 \\
\hline BAK1 & 1 & 1.052255487 & 1.429427856 \\
\hline BAX & 1 & 0.69606945 & 0.997156117 \\
\hline BCL10 & 1 & 1.742757923 & 4.87369761 \\
\hline BCL2 & 1 & 1.630156046 & 2.021612475 \\
\hline$\overline{\text { BCL2A1 }}$ & 1 & 0.859702047 & 6.169988115 \\
\hline BCL2L1 & 1 & 0.972882377 & 1.914230346 \\
\hline BCL2L10 & 1 & 3.24583347 & 1.548205353 \\
\hline BCL2L11 & 1 & 1.806301155 & 2.684853773 \\
\hline BCL2L2 & 1 & 0.818032737 & 1.220264572 \\
\hline BCLAF1 & 1 & 0.514467773 & 1.195566954 \\
\hline BFAR & 1 & 1.756823023 & 2.052141318 \\
\hline BID & 1 & 1.160986918 & 2.100036308 \\
\hline BIK & 1 & 1.178880785 & 0.868161013 \\
\hline NAIP & 1 & 0.910807339 & 1.735113842 \\
\hline BIRC2 & 1 & 1.723334359 & 5.585876182 \\
\hline BIRC3 & 1 & 22.3405351 & 519.9162591 \\
\hline BIRC4 & 1 & 1.562503608 & 3.753454684 \\
\hline BIRC6 & 1 & 1.369515307 & 2.960090185 \\
\hline BIRC8 & 1 & 0.224688536 & 0.596045737 \\
\hline BNIP1 & 1 & 2.490970995 & 5.104761512 \\
\hline BNIP2 & 1 & 1.058442001 & 1.725648544 \\
\hline BNIP3 & 1 & 1.151003293 & 1.131121676 \\
\hline BNIP3L & 1 & 1.190760413 & 1.350999743 \\
\hline BRAF & 1 & 0.994104239 & 2.395083993 \\
\hline NOD1 & 1 & 1.426472351 & 1.540929608 \\
\hline CARD6 & 1 & 4.223160339 & 11.5048907 \\
\hline CARD8 & 1 & 0.927114357 & 2.225643027 \\
\hline CASP1 & 1 & 0.471605332 & 0.479861115 \\
\hline CASP10 & 1 & 1.170304945 & 3.932816237 \\
\hline CASP14 & 1 & 0.31404974 & --- \\
\hline CASP2 & 1 & 0.765375354 & 1.074060834 \\
\hline CASP3 & 1 & 1.764348218 & 2.910804212 \\
\hline
\end{tabular}




\begin{tabular}{|c|c|c|c|}
\hline CASP4 & 1 & 1.820112512 & 2.351206132 \\
\hline CASP5 & 1 & 1.066413814 & 1.287842873 \\
\hline CASP6 & 1 & 2.68212009 & 2.332928266 \\
\hline CASP7 & 1 & 1.252083643 & 2.638100674 \\
\hline CASP8 & 1 & 5.578470041 & 11.0714453 \\
\hline CASP9 & 1 & 0.902237605 & 1.790782599 \\
\hline CD40 & 1 & 2.305545761 & 19.63990456 \\
\hline CD40LG & 1 & 1.286256093 & 1.492965673 \\
\hline CFLAR & 1 & 1.913200514 & 3.87978111 \\
\hline CIDEA & 1 & 2.715094672 & 6.770559994 \\
\hline CIDEB & 1 & 0.506635382 & 0.600169441 \\
\hline CRADD & 1 & 1.990804557 & 3.520758387 \\
\hline DAPK1 & 1 & --- & 1.783566691 \\
\hline DFFA & 1 & 1.463679117 & 1.425095434 \\
\hline FADD & 1 & 1.298336884 & 1.887506614 \\
\hline FAS & 1 & 2.440317695 & 7.834989441 \\
\hline FASLG & 1 & 0.419348938 & 1.205497957 \\
\hline GADD45A & 1 & 6.379998063 & 8.527600933 \\
\hline HRK & 1 & 1.591556557 & 2.076670578 \\
\hline IGF1R & 1 & 2.830869329 & 2.143367141 \\
\hline LTA & 1 & 1.59878174 & 15.29349892 \\
\hline LTBR & 1 & 0.70578131 & 1.012089289 \\
\hline MCL1 & 1 & 1.251408444 & 3.469257479 \\
\hline NOL3 & 1 & 0.582910203 & 0.878870978 \\
\hline PYCARD & 1 & 1.002370401 & 0.762808512 \\
\hline RIPK2 & 1 & 1.554186413 & 3.382725401 \\
\hline TNF & 1 & 1.554919104 & 18.10176355 \\
\hline TNFRSF10A & 1 & 1.408849924 & 1.418218231 \\
\hline TNFRSF10B & 1 & 3.776727789 & 6.924965591 \\
\hline TNFRSF11B & 1 & 0.840021742 & 1.590967579 \\
\hline TNFRSF1A & 1 & 1.456906535 & 1.366794034 \\
\hline TNFRSF21 & 1 & 1.285791084 & 2.50712063 \\
\hline TNFRSF25 & 1 & 0.590175325 & 1.162123364 \\
\hline CD27 & 1 & 1.041429225 & 1.886129643 \\
\hline TNFRSF9 & 1 & 5.954002497 & 301.6144009 \\
\hline TNFRSF10 & 1 & 1.931640815 & 8.744747593 \\
\hline CD70 & 1 & 2.641763494 & 5.563982243 \\
\hline TNFRSF8 & 1 & --- & 0.592829882 \\
\hline TP53 & 1 & 1.012764514 & 0.873731733 \\
\hline TP53BP2 & 1 & 1.822174695 & 3.283161484 \\
\hline TP73 & 1 & 0.225771078 & 0.293858611 \\
\hline TRADD & 1 & 1.038891353 & 1.88954023 \\
\hline TRAF2 & 1 & 1.088226882 & 2.235773374 \\
\hline TRAF3 & 1 & 1.296594095 & 4.22581625 \\
\hline TRAF4 & 1 & 1.350957704 & 4.414901945 \\
\hline
\end{tabular}




\begin{tabular}{|l|c|c|c|}
\hline \multicolumn{1}{|c|}{ Housekeepings } & \multicolumn{3}{|c|}{$\mathbf{2}^{-\Delta \Delta C T}$} \\
\hline B2M & 17.984869 & 18.22633362 & 18.994277 \\
\hline HPRT1 & 21.42886829 & 22.14376545 & 23.41587448 \\
\hline RPL13A & 20.60149097 & 19.07392979 & 20.49731064 \\
\hline GAPDH & 18.69188309 & 19.15331936 & 20.75540733 \\
\hline ACTB & 15.33713484 & 16.60303307 & 18.4476738 \\
\hline \multicolumn{1}{|c|}{ Média Geométrica } & 18.68273663 & 18.95677651 & 20.35075756 \\
\hline & & $2^{-\Delta 4 C T}$ & \\
\hline & CTRL & HF 50 ng/mL & HF 200 ng/mL \\
\hline HGDC & 34.86597443 & 34.92547443 & 34.86868286 \\
\hline RTC & 35.59367752 & 35.82332611 & 35.88016701 \\
\hline RTC & 37.1364975 & 33.71201515 & 34.14324856 \\
\hline RTC & 36.57301331 & 35.70078468 & 35.53795719 \\
\hline PPC & 18.94094181 & 18.426898 & 18.10913706 \\
\hline PPC & 18.99474716 & 18.07367134 & 18.00326824 \\
\hline PPC & 18.912467 & 18.1068449 & 18.07001734 \\
\hline
\end{tabular}


ANEXO C - Resumo do trabalho apresentado na forma de pôster na XXXIX Annual

Meeting of The Brazilian Biochemistry and Molecular Biology Society 2010 (SBBq 2010), em Foz do Iguaçu, PR, Brasil.

Halofuginone Induces Apoptosis by Activation of Death Receptor Signaling in Acute Promyelocytic Leukemia

Assis, P.A. ${ }^{1}$, Figueiredo-Pontes, L.L. ${ }^{1}$, Garcia, A.B. ${ }^{1}$, Greene, L.J. ${ }^{2}$, Rego, E.M. ${ }^{1}$,

${ }^{1}$ Hematology Division and ${ }^{2}$ Department of Molecular and Cell Biology, Medical School of Ribeirão Preto, University of São Paulo, Brazil;

Halofuginone (HF), a low molecular weight quinazolinone alkaloid, has been shown to have a potent antitumor effect in solid tumor models. However, its effects on acute leukemias have not yet been evaluated. In this study, cell proliferation and apoptosis were studied in NB4 promyelocytic cells treated with HF. Using a four color flow cytometric method, we simultaneously analyzed BrdU incorporation, apoptosis and BCL-2 expression in NB4 cells incubated for 12, 24 and 48 hours with increasing doses of HF $(50,100$ and $200 \mathrm{ng} / \mathrm{ml})$. There was a significant dose-dependent inhibition of cell proliferation (percentage of BrdU+ cells was $41.21 \pm 3.25,6.88 \pm 0.34$, $3.26 \pm 2.79$ and $2.09 \pm 0.30$ in non-treated cells, HF50, HF100 and HF200 samples, respectively). In addition, after 48 hours, a five-fold increase in apoptosis was detected with $200 \mathrm{ng} / \mathrm{ml}$ of HF (8.94 \pm 2.08 versus 45.28 \pm 11.56$)$ and, simultaneously, a dramatic reduction in BCL-2 protein expression was observed (38.18 \pm 2.58 versus $0.45 \pm 0.32$ ). A qRT-PCR array including 84 apoptosis related genes revealed more than two-fold increase in the expression of different genes involved in the death receptor signaling. Our findings suggest that HF has important antiproliferative and proapoptotic effects associated with the activation of the death receptor signaling. Thus, HF may have therapeutic potential in APL.

Keywords: APL, halofuginone, apoptosis

Financial Support: FAPESP, CTC and CNPq. 
ANEXO D - Resumo do trabalho apresentado na forma de pôster na XXXIVAnnual Meeting of The Brazilian Society for Immunology 2009 (SBI 2009), em Salvador, BA, Brasil.

REGULATION OF TFG- $\beta$ PATHWAY BY HALOFUGINONE INHIBITS CELL PROLIFERATION AND INDUCES APOPTOSIS IN ACUTE PROMYELOCYTIC LEUKEMIA

PATRICIA A. DE ASSIS ${ }^{1}$, LORENA L. FIGUEIREDO-PONTES ${ }^{1}$, AGLAIR B. GARCIA $^{1}$, MARCIA S. BAGGIO ${ }^{1}$, ARNON NAGLER $^{2}$, EDUARDO M. REGO ${ }^{1}$.

${ }^{1}$ Hematology Division and National Institute of Sciences and Technology in Stem Cell and Cell Therapy, Medical School of Ribeirão Preto, University of São Paulo, Brazil; ${ }^{2}$ Department of Bone Marrow Transplantation, Chaim Sheba Medical Center, Tel Hashomer, Israel.

Introduction and Objectives: Halofuginone (HF), a low molecular weight quinazolinone alkaloid, has been show to reduce tumor growth by modulating the TFG- $\beta$ pathway. The tumor suppressor protein PML is an essential regulator of TFG$\beta$ signaling by physical interacting with $S$ mad2/3 complex. Acute promyelocytic leukemia (APL) is characterized by the expression of the PML/RAR $\alpha$ fusion protein generated by $t(15,17)$. PML/RARa exerts a dominant negative action on PML, and thus indirectly leads to deregulation of TFG- $\beta$ pathway. However, the cross talk between PML and TFG- $\beta$ pathways in APL has been poorly characterized and effects of HF in acute leukemias have not yet been evaluated. To address this issue, we have analyzed the effects of HF in APL cell line NB4. Methods and Results: Using a four color flow cytometric method, we simultaneously analyzes BrdU incorporation, apoptosis and Bcl-2 expression in NB4 cells incubated for 12, 24 and 48 hours with increasing doses of HF (50, 100 and $200 \mathrm{ng} / \mathrm{ml})$. There was a significant inhibition of cell proliferation in a dose-dependent fashion (\% of BrDU+ cells: CT:41.21 \pm 3.25 ; HF50:6.88 \pm 0.34 ; HF100:3.26 \pm 2.79 and HF200:2.09 \pm 0.30$)$. In addition, after 48 hours a 5,0 fold increase in the percentage of apoptotics cells was

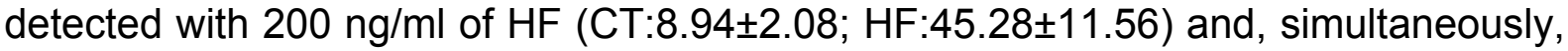
a drastic reduction in the percentage of $\mathrm{Bcl}-2$ protein expression (CT:38.18 \pm 2.58 ; $H F: 0.45 \pm 0.32$ ). The TFG- $\beta$ pathway activation was evaluated by quantifying phosphorylated Smad2 (P-Smad2) protein levels using an ELISA assay. An increase of P-Smad2 levels was detected in samples treated with $100 \mathrm{ng} / \mathrm{ml}$ of HF starting at 24 hours of treatment (CT:1.56 \pm 0.0 ; HF100:1.86 \pm 0.03$)$. Conclusions: HF has an important antiproliferative and proapoptotic effect, which was associated with the activation of the TFG- $\beta$ pathway. Thus, HF may have therapeutic potential in APL.

Financial Support: FAPESP, CTC and CNPq. 